Special-Status Plant Species Surveys and Vegetation Mapping at Lawrence Livermore National Laboratory

R. E. Preston

October 3, 2006 
This document was prepared as an account of work sponsored by an agency of the United States Government. Neither the United States Government nor the University of California nor any of their employees, makes any warranty, express or implied, or assumes any legal liability or responsibility for the accuracy, completeness, or usefulness of any information, apparatus, product, or process disclosed, or represents that its use would not infringe privately owned rights. Reference herein to any specific commercial product, process, or service by trade name, trademark, manufacturer, or otherwise, does not necessarily constitute or imply its endorsement, recommendation, or favoring by the United States Government or the University of California. The views and opinions of authors expressed herein do not necessarily state or reflect those of the United States Government or the University of California, and shall not be used for advertising or product endorsement purposes.

This work was performed under the auspices of the U.S. Department of Energy by University of California, Lawrence Livermore National Laboratory under Contract W-7405-Eng-48. 


\title{
Special-Status Plant Species Surveys and Vegetation Mapping at Lawrence Livermore National Laboratory
}

\author{
Prepared for: \\ Lawrence Livermore National Laboratory \\ 7000 East Avenue \\ P.O. Box 808 \\ Livermore, CA 94550 \\ Contact: Michael van Hattem \\ 925/424-6795 \\ Prepared by: \\ Jones \& Stokes \\ $2600 \mathrm{~V}$ Street \\ Sacramento, CA 95818-1914 \\ Contact: Robert E. Preston, Ph.D. \\ 916/503-6681
}


Jones \& Stokes. 2002. Special-Status Plant Species Surveys and Vegetation Mapping at Lawrence Livermore National Laboratory. Prepared for Lawrence Livermore National Laboratory. September. (J\&S 02-136.) Sacramento, CA. 


\section{Contents}

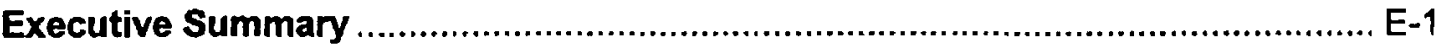

Section A. Special-Status Plant Surveys at Site $300 \ldots \ldots \ldots \ldots \ldots \ldots \ldots \ldots \ldots \ldots \ldots \ldots \ldots \ldots \ldots . . . . . . . .14$

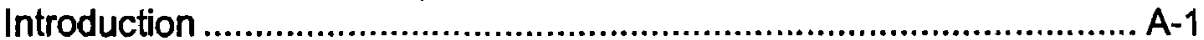

Project Description ............................................................................. A-1

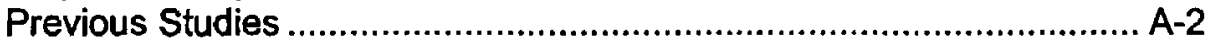

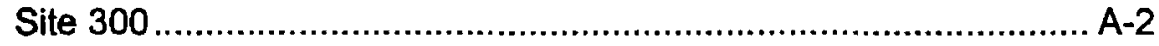

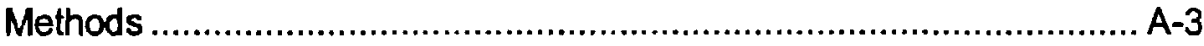

Prefield Review ........................................................................ A-3

Field Surveys .............................................................................. A-4

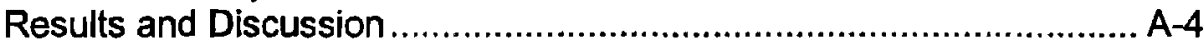

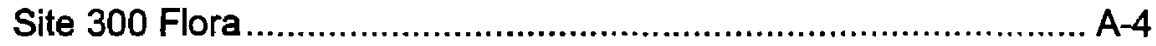

Special-Status Plant Species.......................................................... A-6

Additional Recommendations .................................................. A-16

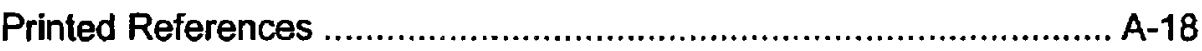

Personal Communications ......................................................... A-20

Appendix A-1. Annotated Checklist of the Vascular Plants of

Lawrence Llvermore Laboratory Site $\mathbf{3 0 0}$

Appendix A-2. California Native Specles Survey Forms

Section B. Lawrence Llvermore National Laboratory Livermore

Site Assessment ............................................................................ B-1

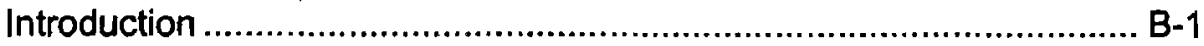

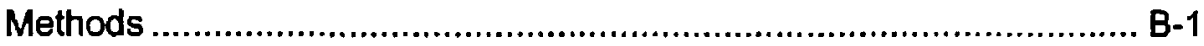

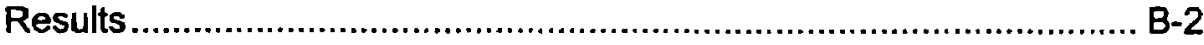

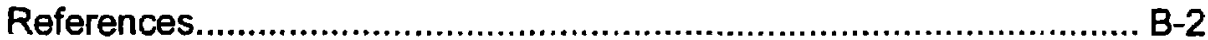

Section C. Vegetation Map and Natural Community Classification

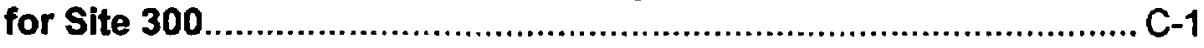

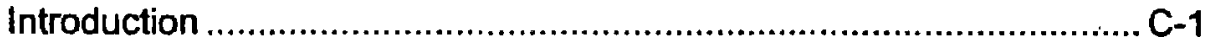

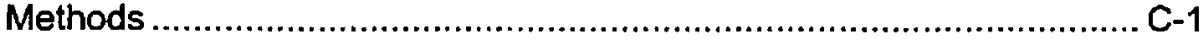

Community Type Classification ........................................................ C-2

Natural Community Types .......................................................... C-2

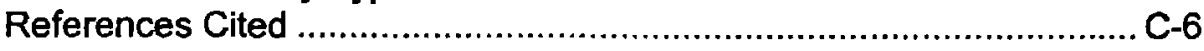




\section{Tables and Figures}

A-1. Special-Status Plant Species Occurring in Vicinity of Site 300 ...............A-4

A-2. 1997 Census of Blepharizonia plumosa at Site 300 ........................... A-8

B-1. Special-Status Plant Species Occurring in the Vicinity of

Livermore Site

B-2. Checklist of Plant Species Observed in Arroyo Seco, Livermore Site

C-1. A Habitat Classification for Site 300

C-2

\section{Figure}

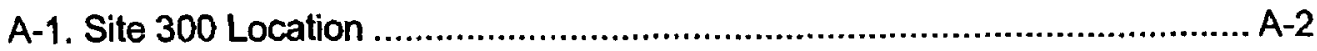

A-2. Locations of Special-Status Plants, 1997 ....................................... A-6

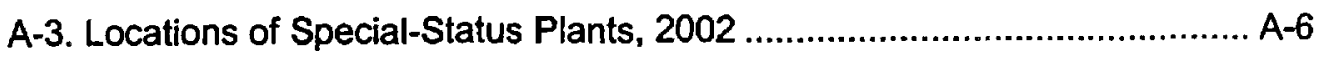

B-1. Lawrence Livermore National Laboratory ............................................ B-3 


\section{Executive Summary}

This report presents the results of Jones \& Stokes' special-status plant surveys and vegetation mapping for the University of California, Lawrence Livermore National Laboratory (LLNL). Special-status plant surveys were conducted at Site 300 in April to May 1997 and in March to April 2002. Eight special-status plants were identified at Site 300: large-flowered fiddleneck, big tarplant, diamond-petaled poppy, round-leaved filaree, gypsum-loving larkspur, California androsace, stinkbells, and hogwallow starfish. Maps identifying the locations of these species, a discussion of the occurrence of these species at Site 300, and a checklist of the flora of Site 300 are presented. A reconnaissance survey of the LLNL Livermore Site was conducted in June 2002. This survey concluded that no special-status plants occur at the Livermore Site. Vegetation mapping was conducted in $200 \mathrm{l}$ at Site 300 to update a previous vegetation study done in 1986. The purpose of the vegetation mapping was to update and to delineate more precisely the boundaries between vegetation types and to map vegetation types that previously were not mapped. The vegetation map is presented with a discussion of the vegetation classification used. 
-

$-$ 


\section{Section A \\ Special-Status Plant Surveys at Site $\mathbf{3 0 0}$}

\section{Introduction}

This section presents the results of Jones \& Stokes' special-status plant surveys for LLNL, Site 300. Special-status plants are species listed as threatened or endangered under the federal Endangered Species Act (ESA), species listed as threatened or endangered under the California Endangered Species Act, species listed as rare under the California Native Plant Protection Act, species that are proposed for listing or are candidates for listing under the federal and state ESAs, and species subject to review under the California Environmental Quality Act (CEQA), including species listed in the California Native Plant Society's (CNPS's) Inventory of Rare and Endangered Plants of California (California Native Pant Society 2001). The objectives of these surveys were to complete a sitewide floristic survey of Site 300 to determine the occurrence and distribution of specialstatus plants, and to update information obtained during previous surveys. The results of these surveys will be used by LLNL in siting future projects and to evaluate the impacts of current and future operations.

\section{Project Description}

Site 300 occupies approximately 2,800 hectares $(6,860$ acres) straddling the border between Alameda and San Joaquin Counties, approximately 24 kilometers (15 miles) southeast of the City of Livermore (Figure A-1). Site 300 is a U.S. Department of Energy experimental test site operated by the University of California and is used primarily for high explosives testing activities (U.S. Department of Energy and University of California 1992). Test facilities on the site include remote firing areas, storage magazines, and a chemistry processing area. Administrative facilities include a fire station, medical services, a cafeteria, maintenance and storage buildings, security facilities, offices, wastewater facilities, and roads that occur primarily in the southern half of the property. A controlled burning program has been carried out annually on Site 300 since 1960, primarily in the northern half of the site and perimeter areas. Numerous unpaved fire roads traverse the site. 


\section{Previous Studies}

\section{Site 300}

The vegetation types present at Site 300 were surveyed and mapped in 1986 (BioSystems 1986a). This survey consisted of intense sampling of 218 representative relevés. The study described four main vegetation types present. Most of the vegetation at Site 300 is annual grassland dominated by introduced grasses (Avena, Bromus sp.). Perennial grasslands are scattered around the site, but are most abundant in the northern half, where they appear to be associated with areas subject to annual controlled burning. The perennial grassland is dominated by native perennial grasses (Poa secunda, Nassella sp.). A small amount of oak woodland is present in the southern canyons of Site 300, mostly on north-facing slopes. The oak woodland consists of scattered blue oak (Quercus douglasii) and valley oak (Q. lobata) with an understory of annual grassland. Coastal scrub, present predominantly on steep, rocky slopes in the southwestern portion of the Site 300, is dominated by soft chaparral scrubs, including California sage (Artemisia californica), California buckwheat (Eriogonum fasciculatum), black sage (Salvia mellifera), and California matchweed (Gutierrezia californica). Other less common vegetation types include wetlands associated with seeps and springs along the intermittent streams that drain the site, vernal pools, and small stands of riparian scrub.

A rare plant survey was also conducted between March 30 and mid-May, 1986 (BioSystems 1986b). This survey consisted of a reconnaissance-level survey of the entire site. The survey focused on habitats with the best potential to support rare plant species, based on a list of target species developed from literature and database research. Data generated from the sitewide relevé sampling were also reviewed for the presence of rare plant species. Additionally, a census was performed on the large-flowered fiddleneck (Amsinckia grandiflora) population occurring at the Drop Tower site. No new populations of rare plants were observed. The survey identified a CNPS List 4 species, gypsum-loving larkspur (Delphinium gypsophilum var. gypsophilum), occurring on Site 300.

Rare plant surveys were conducted in 1991 in preparation for the environmental impact statement/environmental impact report (EIS/EIR)for the continued operation of LLNL (U.S. Department of Energy and University of California 1992). These surveys focused on potential habitat for large-flowered fiddleneck along the canyons in the southern portion of Site 300. During this survey, two populations of large-flowered fiddleneck were noted: the Drop Tower population and a second small population (also known as the "Draney Canyon" population) that had been found in 1989. Two populations of gypsum-loving larkspur were noted and mapped.

In 1996, Jones \& Stokes conducted a reconnaissance visit to Site 300 to conduct a habitat assessment for big tarplant (Blepharizonia plumosa), which had recently been recognized as a rare plant with potential to occur at Site 300 . During the site 


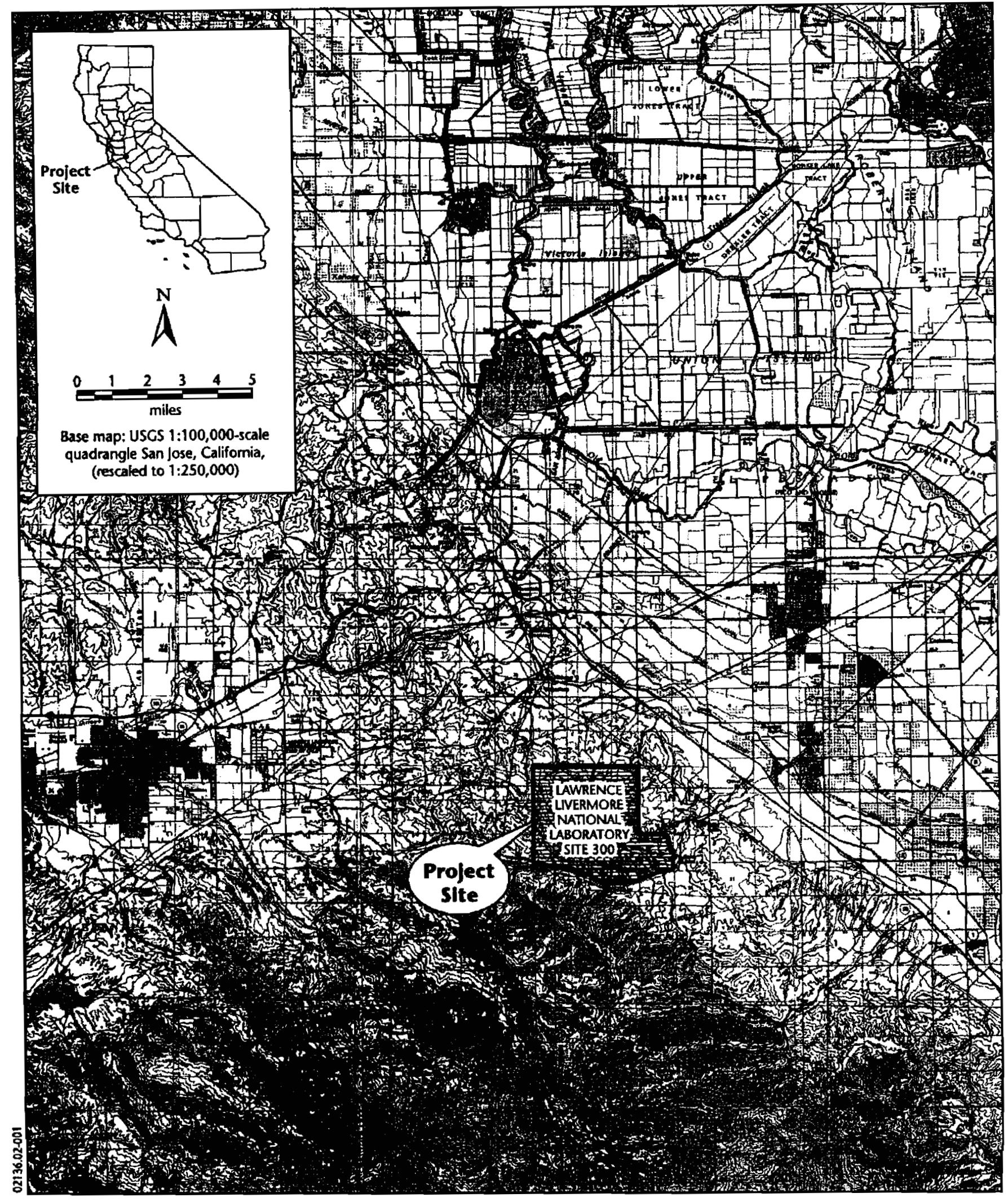

I5s Jones \& Stokes

Figure A-1

Site $\mathbf{3 0 0}$ Location, Lawrence Livermore National Laboratory, Alameda/San Joaquin County, California 
visit on September 27, 1996, and during a follow-up visit with LLNL staff on October 4, 1996, five big tarplant populations were discovered. Populations were found at the Building 834 complex; in Elk Ravine, northeast of Building 834; near the Building 812 complex; adjacent to Building 801 ; and near Building 850 . In addition, individual plants were observed at scattered locations along roads and in disturbed areas. The presence of this species, previously undocumented from Site 300 , demonstrated the need for a comprehensive sitewide rare plant survey.

Monitoring and management of rare plant populations at Site 300 has been taking place at Site 300 since the mid-1990s (Carlsen et al. 1998, 1999, 2001, 2002). These studies initially focused on large-flowered fiddleneck but have expanded to include the other rare plants subsequently identified at Site 300 . These studies have included research on restoration measures for large-flowered fiddleneck; research on the demography, population ecology, and response to fire by big tarplant; censusing the population of diamond-petaled poppy (Eschscholzia rhombipetala) and characterization of its habitat; and a focused field survey of stands of gypsum-loving larkspur.

\section{Methods}

Jones \& Stokes performed two rounds of surveys for special-status plants at Site 300. The first surveys were performed in late spring, 1997, and the second surveys were performed in early spring 2002 . Each round of surveys was preceded by a review of available information regarding known special-status plants occurring in the vicinity of Site 300 .

\section{Prefield Review}

Before conducting the field work in 1997, Jones \& Stokes botanists reviewed existing information on the potential occurrence of special-status plants at Site 300, including the previous Site 300 vegetation survey (BioSystems 1986a) and rare plant survey (BioSystems 1986b), conducted a search of the California Natural Diversity Database (CNDDB) in 1996, and reviewed a list of special-status plant species occurring in the vicinity of Site 300, compiled from previous reports (U.S. Department of Energy and University of California 1992) and resource agency letters (Aasen pers. comm., Medlin pers. comm.). Based on this information, we generated a list of special-status plant species potentially occurring on Site 300 (Table A-1). Table A-1 includes species not likely to be found at Site 300 because the habitat in which they occur is not present at Site 300; however, these species are included to demonstrate that all species occurring in the vicinity of Site 300 have been reviewed. Table A-1 includes species on CNPS List 4. Although species on List 4 are not currently considered to face the same level of threat or rarity faced by listed species or species eligible for listing, they have potential to do so in the foreseeable future. Table A-1 formed the basis for scheduling field surveys and selecting areas to be surveyed. 
We reviewed the list in 2002 and revised it to include new information recorded in the CNDDB (2002) or reported by CNPS (2001a, 2001b).

\section{Field Surveys}

To the extent possible, field surveys followed California Department of Fish and Game (DFG) guidelines (California Department of Fish and Game 1984, 2000). In 1997, we performed field surveys between April 30 and May 12 and on September 23. Because the contract to perform surveys was not awarded until late April, early spring surveys were not possible. During the April-May survey period, Jones \& Stokes personnel traversed the entire site by foot, sampling vegetation along meandering transects that paralleled roads and fire breaks. We identified all plants encountered along the transects to the extent possible; at a minimum, we identified every taxon to the extent necessary to determine whether it had special status. A single running checklist was accumulated over the survey period. During the September survey, we traveled the site by vehicle to survey areas where big tarplant rosettes had been seen during the spring survey and to search for any additional populations. Big tarplant has large, showy flowers and is easily observed from over 100 meters away. At each occurrence of special-status species, we mapped the extent of the population onto a 1:7200-scale topographic base map, visually estimating the extent of the population. We estimated the number of individuals and made observations on the habitat and associated species. A standard California Native Species Field Survey Form was filled out for each species (Appendix A-2). Approximately 203 person-hours were spent on the surveys.

In 2002, we performed field surveys between March 27 and April 3. Surveys were generally performed as in 1997 . However, the transects were intuitively controlled, that is the surveyors determined the location and direction of transects by visually assessing the terrain ahead for microhabitats with higher potential for the occurrence of special-status species, as indicated by the plant community present, topography, slope aspect, and the presence of features such as rock outcrops or wetlands. Each surveyor kept a running species list for each transect. Thirty-five transects were sampled over a period of approximately 223 person-hours. Specialstatus plants were documented in a similar manner as in 1997; however, mapping of each population was done by collecting point and polygon data using Global Positioning System (GPS) recorders.

\section{Results and Discussion}

\section{Site $\mathbf{3 0 0}$ Flora}

Jones \& Stokes recorded 281 plant species at Site 300 in 1997 and an additional 84 plant species in 2002. From these results and the results of previous surveys (BioSystems 1986), a checklist of plants at Site 300 was prepared that includes 406 plant species (see Appendix A-1). The flora at Site 300 appears to be fairly 
Table A-1. Special-Status Plant Species Recorded in the Vicinity of Lawrence Livermore National Laboratory, Site 300.

Page 1 of 7

\begin{tabular}{|c|c|c|c|}
\hline \multicolumn{4}{|c|}{ Listing Status* } \\
\hline Common and Scientific Name & Federal/State/CNPS & Habitat & Occurrence in Site 300 Vicinity \\
\hline \multicolumn{4}{|c|}{ 1) Species potentially occurring on Site 300 (potential habitat present) } \\
\hline $\begin{array}{l}\text { Large-flowered fiddleneck } \\
\text { Amsinckia grandiflora }\end{array}$ & $\mathrm{E} / \mathrm{E} / 1 \mathrm{~B}$ & $\begin{array}{l}\text { Valley grassland slopes below } 1,200 \\
\text { feet; blooms April-May }\end{array}$ & 1 extant occurrence at Site 300 \\
\hline $\begin{array}{l}\text { Big scale balsamroot } \\
\text { Balsamorhiza macrolepis }\end{array}$ & $-/-/ 1 \mathrm{~B}$ & $\begin{array}{l}\text { Fields and rocky hillsides, below } \\
2,000 \text { feet; grassland, foothill } \\
\text { woodland; blooms March-June }\end{array}$ & $\begin{array}{l}\text { Southeast of Livermore; not found at } \\
\text { Site } 300\end{array}$ \\
\hline $\begin{array}{l}\text { Big tarplant } \\
\text { Blepharizonia plumosa }\end{array}$ & $-1-11 B$ & $\begin{array}{l}\text { Annual grassland, on clay soils; } \\
\text { blooms July-October }\end{array}$ & Common and widespread at Site 300 \\
\hline $\begin{array}{l}\text { Mt. Diablo fairy lantern } \\
\text { Calochortus pulchellus }\end{array}$ & $-1-11 \mathrm{~B}$ & $\begin{array}{l}\text { Cismontane woodland; chaparral; } \\
\text { blooms April-June }\end{array}$ & $\begin{array}{l}\text { No nearby occurrences; not found at } \\
\text { Site } 300\end{array}$ \\
\hline $\begin{array}{l}\text { Hoover's cryptantha } \\
\text { Cryptantha hooveri }\end{array}$ & $-1-11 B$ & $\begin{array}{l}\text { Coarse sandy soil in grasslands; } \\
\text { blooms April-May }\end{array}$ & $\begin{array}{l}\text { No nearby occurrences, although Site } \\
300 \text { is in species' range; not found at } \\
\text { Site } 300\end{array}$ \\
\hline $\begin{array}{l}\text { Hospital Canyon larkspur } \\
\text { Delphinium californicum } \\
\text { var. interius }\end{array}$ & $-1-11 B$ & $\begin{array}{l}\text { Moist ravines and slopes in } \\
\text { woodlands; blooms March-May. }\end{array}$ & $\begin{array}{l}\text { Hospital Canyon; Cedar Mountain; not } \\
\text { found at Site } 300\end{array}$ \\
\hline $\begin{array}{l}\text { Mt. Diablo buckwheat } \\
\text { Eriogonum truncatum }\end{array}$ & $-1-11 A$ & $\begin{array}{l}\text { Coarse sandy soil in grasslands; } \\
\text { blooms April-September }\end{array}$ & Corral Hollow; not found at Site 300 \\
\hline $\begin{array}{l}\text { Round-leaved filaree } \\
\text { Erodium macrophyllum }\end{array}$ & $-1-12$ & $\begin{array}{l}\text { Grasslands, on friable clay soils; } \\
\text { blooms March-May }\end{array}$ & $\begin{array}{l}\text { Comal Hollow; Altamont Pass; } 1 \\
\text { occurrence at Site } 300\end{array}$ \\
\hline $\begin{array}{c}\text { Diamond-petaled Califomia poppy } \\
\text { Eschscholzia rhombipetala }\end{array}$ & $-1-11 B$ & $\begin{array}{l}\text { Clay soils in grasslands; blooms } \\
\text { March-April }\end{array}$ & 2 occurrences at Site 300 \\
\hline
\end{tabular}




\begin{tabular}{|c|c|c|c|}
\hline \multicolumn{4}{|c|}{ Listing Status* } \\
\hline Common and Scientific Name & Federal/State/CNPS & Habitat & Occurrence in Site 300 Vicinity \\
\hline $\begin{array}{l}\text { Diablo helianthella } \\
\text { Helianthella castanea }\end{array}$ & $-1-11 B$ & $\begin{array}{l}\text { Grassy slopes in oak woodland, } \\
\text { chaparral; blooms April-June }\end{array}$ & $\begin{array}{l}\text { East of Cedar Mountain; not found at } \\
\text { Site } 300\end{array}$ \\
\hline $\begin{array}{l}\text { Congdon's tarplant } \\
\text { Centromadia parryi var. } \\
\text { congdonii }\end{array}$ & $-1-11 \mathrm{~B}$ & $\begin{array}{l}\text { Annual grasslands; blooms June- } \\
\text { November }\end{array}$ & $\begin{array}{l}\text { West of Livermore; not found at Site } \\
300\end{array}$ \\
\hline $\begin{array}{l}\text { Showy madia } \\
\text { Madia radiata }\end{array}$ & $-/-/ 1 \mathrm{~B}$ & $\begin{array}{l}\text { Annual grassland, on open slopes } \\
\text { with clay soils; blooms March-May }\end{array}$ & $\begin{array}{l}\text { Corral Hollow; Hospital Canyon; not } \\
\text { found at Site } 300\end{array}$ \\
\hline $\begin{array}{l}\text { Hall's bush mallow } \\
\qquad \text { Malacothamnus hallii }\end{array}$ & $-1-/ 1 \mathrm{~B}$ & $\begin{array}{l}\text { Chaparral, coastal scrub; blooms } \\
\text { May-September }\end{array}$ & $\begin{array}{l}\text { East of Hospital Canyon; not found at } \\
\text { Site } 300\end{array}$ \\
\hline $\begin{array}{l}\text { Mt. Diablo cottonweed } \\
\text { Micropus amphibolus }\end{array}$ & $-1-13$ & $\begin{array}{l}\text { Rocky or gravelly soils in chaparral, } \\
\text { woodlands; April-May }\end{array}$ & $\begin{array}{l}\text { No nearby occurrences; not found at } \\
\text { Site } 300\end{array}$ \\
\hline $\begin{array}{l}\text { Showy Indian clover } \\
\text { Trifolium amoenum }\end{array}$ & $\mathrm{E} /-/ 1 \mathrm{~B}$ & $\begin{array}{l}\text { Grasslands in valleys and swales; } \\
\text { blooms April-June }\end{array}$ & $\begin{array}{l}\text { No nearby occurrences, although Site } \\
300 \text { is in species' range; not found at } \\
\text { Site } 300\end{array}$ \\
\hline $\begin{array}{l}\text { Caper-fruited tropidocarpum } \\
\text { Tropidocarpum capparideum }\end{array}$ & $-1-11 A$ & $\begin{array}{l}\text { Grasslands in alkaline hills below } \\
500 \text { feet; blooms March-April }\end{array}$ & $\begin{array}{l}\text { Livermore; Midway; Mountain House; } \\
\text { Byron; not found at Site } 300\end{array}$ \\
\hline \multicolumn{4}{|c|}{ 2) Species unlikely to occur on Site 300 (potential babitat not present) } \\
\hline $\begin{array}{l}\text { Sharsmith's onion } \\
\text { Allium sharsmithii }\end{array}$ & $-11 \mathrm{~B}$ & $\begin{array}{l}\text { Rocky serpentine slopes, in } \\
\text { chaparral or cypress woodland; } \\
\text { blooms March-May }\end{array}$ & Cedar Mountain; not found at Site 300 \\
\hline $\begin{array}{l}\text { Ferris' milk-vetch } \\
\qquad \text { Astragalus tener var. ferrisiae }\end{array}$ & $-1-11 B$ & $\begin{array}{l}\text { Subalkaline flats and floodlands, } \\
\text { usually on adobe soil }\end{array}$ & Mountain House; not found at Site 300 \\
\hline
\end{tabular}




\begin{tabular}{|c|c|c|c|}
\hline \multirow[b]{2}{*}{ Common and Scientific Name } & \multicolumn{3}{|l|}{ Listing Status* } \\
\hline & Federal/State/CNPS & Habitat & Occurrence in Site 300 Vicinity \\
\hline $\begin{array}{l}\text { Alkali milkvetch } \\
\quad \text { Astragalus tener var. tener }\end{array}$ & $-1-11 B$ & $\begin{array}{l}\text { Subalkaline flats and areas around } \\
\text { vernal pools; blooms March-June }\end{array}$ & $\begin{array}{l}\text { Livermore Valley; Byron; not found at } \\
\text { Site } 300\end{array}$ \\
\hline $\begin{array}{l}\text { Heartscale } \\
\qquad \text { Atriplex cordulata }\end{array}$ & $-1-11 \mathrm{~B}$ & $\begin{array}{l}\text { Alkali grassland, alkali meadow, } \\
\text { alkali scrub; blooms May-October }\end{array}$ & $\begin{array}{l}\text { Reported occurrences in Site } 300 \\
\text { vicinity are erroneous; not found at } \\
\text { Site } 300\end{array}$ \\
\hline $\begin{array}{l}\text { Brittlescale } \\
\quad \text { Atriplex depressa }\end{array}$ & $-1-/ 1 \mathrm{~B}$ & $\begin{array}{l}\text { Alkali grassland, alkali meadow, } \\
\text { alkali scrub; blooms June-October }\end{array}$ & $\begin{array}{l}\text { Livermore; Altamont Pass; Byron Hot } \\
\text { Springs; Kellogg Creek watershed; not } \\
\text { found at Site } 300\end{array}$ \\
\hline $\begin{array}{l}\text { San Joaquin saltbush } \\
\text { Atriplex joaquiniana }\end{array}$ & $-1-/ 1 \mathrm{~B}$ & $\begin{array}{l}\text { Alkaline meadows, chenopod scrub; } \\
\text { blooms April-September }\end{array}$ & $\begin{array}{l}\text { Livermore; Altamont Pass; Byron Hot } \\
\text { Springs; Kellogg Creek watershed; not } \\
\text { found at Site } 300\end{array}$ \\
\hline $\begin{array}{l}\text { Mount Hamilton coreopsis } \\
\text { Coreopsis hamiltonii }\end{array}$ & $-\dashv 1 B$ & $\begin{array}{l}\text { Steep shale talus slopes; blooms } \\
\text { March-May }\end{array}$ & $\begin{array}{l}\text { Cedar Mountain; Mount Oso; not } \\
\text { found at Site } 300\end{array}$ \\
\hline $\begin{array}{l}\text { Hispid bird's-beak } \\
\text { Cordylanthus mollis subsp. } \\
\text { hispidus }\end{array}$ & $-1 / 1 B$ & $\begin{array}{l}\text { Alkaline meadows; blooms June- } \\
\text { September }\end{array}$ & Livermore; not found at Site 300 \\
\hline $\begin{array}{l}\text { Palmate bird's-beak } \\
\text { Cordylanthus palmatus }\end{array}$ & $\mathrm{E} / \mathrm{E} / 1 \mathrm{~B}$ & $\begin{array}{l}\text { Alkaline grasslands, chenopod } \\
\text { scrub; blooms May-October }\end{array}$ & Livermore; not found at Site 300 \\
\hline $\begin{array}{l}\text { Mount Hamilton thistle } \\
\text { Cirsium fontinale var. } \\
\text { campylon }\end{array}$ & $-1-11 \mathrm{~B}$ & $\begin{array}{l}\text { Serpentine seeps and streams; } \\
\text { blooms April-October }\end{array}$ & Cedar Mountain; not found at Site 300 \\
\hline $\begin{array}{l}\text { Livermore tarplant } \\
\text { Deinandra bacigalupii }\end{array}$ & $-t-/ 1 \mathrm{~B}$ & $\begin{array}{l}\text { Alkali meadow; blooms June- } \\
\text { October }\end{array}$ & Livermore; not found at Site 300 \\
\hline
\end{tabular}




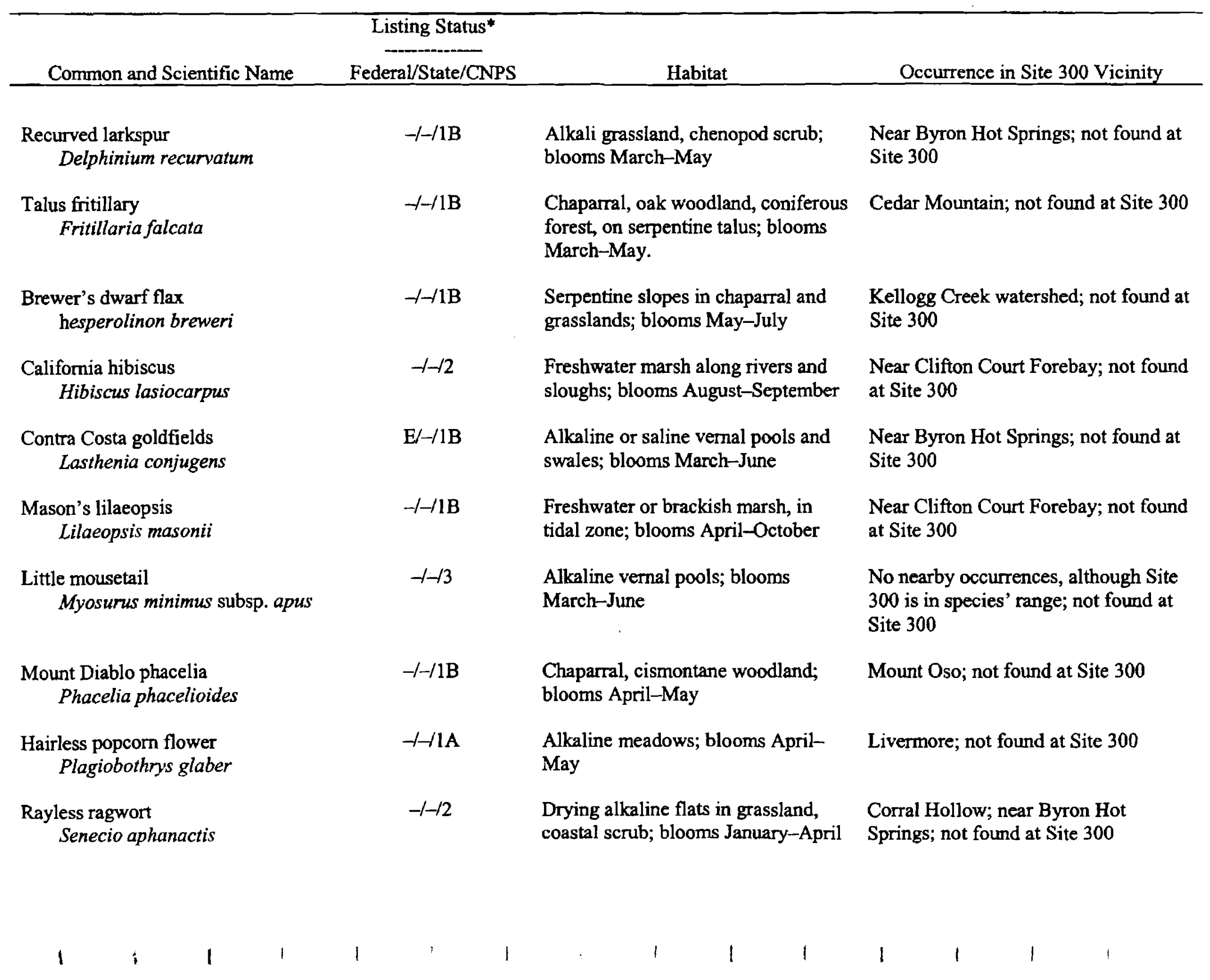




\begin{tabular}{|c|c|c|c|}
\hline \multicolumn{4}{|c|}{ Listing Status* } \\
\hline Common and Scientific Name & Federal/State/CNPS & Habitat & Occurrence in Site 300 Vicinity \\
\hline \multicolumn{4}{|c|}{ 3) Species not currently considered to be threatened or endangered but with potential to become so in foreseeable future } \\
\hline $\begin{array}{l}\text { Santa Clara thorn-mint } \\
\text { Acanthomintha lanceolata }\end{array}$ & $-1-14$ & $\begin{array}{l}\text { Chaparral, coastal scrub, cismontane } \\
\text { woodland, often on serpentine; } \\
\text { blooms March-June. }\end{array}$ & Corral Hollow; not found at Site 300 \\
\hline $\begin{array}{l}\text { California androsace } \\
\text { Androsace elongata subsp. } \\
\text { acuta }\end{array}$ & $-1-14$ & $\begin{array}{l}\text { Moss-covered rock outcrops and } \\
\text { open areas in adjacent grassland. }\end{array}$ & $\begin{array}{l}\text { Widespread and common at Site } 300 \text {, } \\
\text { although restricted to specific } \\
\text { microsites }\end{array}$ \\
\hline $\begin{array}{l}\text { Crownscale } \\
\quad \text { Atriplex coronata var. coronata }\end{array}$ & $-1-14$ & $\begin{array}{l}\text { Alkali grassland, alkali meadow, } \\
\text { alkali scrub; blooms May-October }\end{array}$ & $\begin{array}{l}\text { Livermore; Altamont Pass; near } \\
\text { Byron; habitat/species not found at } \\
\text { Site } 300\end{array}$ \\
\hline $\begin{array}{l}\text { Brewer's clarkia } \\
\text { Clarkia breweri }\end{array}$ & $-1-14$ & $\begin{array}{l}\text { Chaparral, coastal scrub, cismontane } \\
\text { woodland, often on serpentine; } \\
\text { blooms April-May }\end{array}$ & $\begin{array}{l}\text { Cedar Mountain; Del Puerto Canyon; } \\
\text { not found at Site } 300\end{array}$ \\
\hline $\begin{array}{l}\text { Santa Clara red ribbons } \\
\text { Clarkia concinna var. automixa }\end{array}$ & $-1-14$ & $\begin{array}{l}\text { Mesic, shaded oak woodlands; } \\
\text { blooms April-July }\end{array}$ & Cedar Mountain; not found at Site 300 \\
\hline $\begin{array}{l}\text { Gypsum-loving larkspur } \\
\text { Delphinium gypsophilum } \\
\text { subsp. gypsophilum }\end{array}$ & $-1-14$ & $\begin{array}{l}\text { Grasslands, atriplex scrab; blooms } \\
\text { April-May }\end{array}$ & $\begin{array}{l}\text { Midway; Del Puerto Canyon; several } \\
\text { occurrences at Site } 300\end{array}$ \\
\hline $\begin{array}{l}\text { Jepson's woolly sunflower } \\
\text { Eriophyllum jepsonii }\end{array}$ & $-1-14$ & $\begin{array}{l}\text { Chaparral, coastal scrub, cismontane } \\
\text { woodland; }\end{array}$ & $\begin{array}{l}\text { Corral Hollow; Del Puerto Canyon; } \\
\text { not found at Site } 300\end{array}$ \\
\hline $\begin{array}{l}\text { Stinkbells } \\
\quad \text { Fritillaria agrestis }\end{array}$ & $-1-14$ & $\begin{array}{l}\text { Adobe soils in grassland or foothill } \\
\text { woodland; blooms March-April }\end{array}$ & $\begin{array}{l}\text { Livermore; Corral Hollow; Kellogg } \\
\text { Creek watershed; several occurrences } \\
\text { at Site } 300\end{array}$ \\
\hline
\end{tabular}




\begin{tabular}{|c|c|c|c|}
\hline \multicolumn{4}{|c|}{ Listing Status* } \\
\hline Common and Scientific Name & Federal/State/CNPS & Habitat & Occurrence in Site 300 Vicinity \\
\hline $\begin{array}{l}\text { Serpentine bedstraw } \\
\text { Galium andrewsii subsp. } \\
\text { gatense }\end{array}$ & $-1-14$ & $\begin{array}{l}\text { Chaparral, cismontane woodland, } \\
\text { lower montane coniferous forest; } \\
\text { blooms April-July }\end{array}$ & $\begin{array}{l}\text { Del Puerto Canyon; not found at Site } \\
300\end{array}$ \\
\hline $\begin{array}{l}\text { Hogwallow starfish } \\
\text { Hesperevax caulescens }\end{array}$ & $-1-14$ & $\begin{array}{l}\text { Grasslands, in mesic areas with clay } \\
\text { soils; blooms March-June }\end{array}$ & 1 occurrence at Site 300 \\
\hline $\begin{array}{l}\text { Serpentine linanthus } \\
\text { Linanthus ambiguus }\end{array}$ & $-1-14$ & $\begin{array}{l}\text { Cismontane woodland, coastal } \\
\text { scrub, grasslands, usually on } \\
\text { serpentine; blooms March-June }\end{array}$ & $\begin{array}{l}\text { Livermore; Cedar Mountain; Del } \\
\text { Puerto Canyon; not found at Site } 300\end{array}$ \\
\hline $\begin{array}{l}\text { Sylvan microseris } \\
\text { Microseris sylvatica }\end{array}$ & $-1-14$ & $\begin{array}{l}\text { Grassland, chaparral, cismontane } \\
\text { woodland, Great Basin scrub, } \\
\text { pinyon-juniper woodland; blooms } \\
\text { March-June }\end{array}$ & $\begin{array}{l}\text { Del Puerto Canyon; not found at Site } \\
300\end{array}$ \\
\hline $\begin{array}{l}\text { Cotula navarretia } \\
\quad \text { Navarretia cotulifolia }\end{array}$ & $-\dashv-14$ & $\begin{array}{l}\text { Grassland, chaparral, cismontane } \\
\text { woodland, on adobe soils; blooms } \\
\text { May-June }\end{array}$ & Livermore; not found at Site 300 \\
\hline \multicolumn{4}{|l|}{ *Status explanations: } \\
\hline $\begin{array}{l}\text { Federal } \\
\qquad \begin{aligned}- & =\text { no status } \\
E & =\text { Listed as "endanger }\end{aligned}\end{array}$ & Inder the federal Endar & gered Species Act. & \\
\hline
\end{tabular}




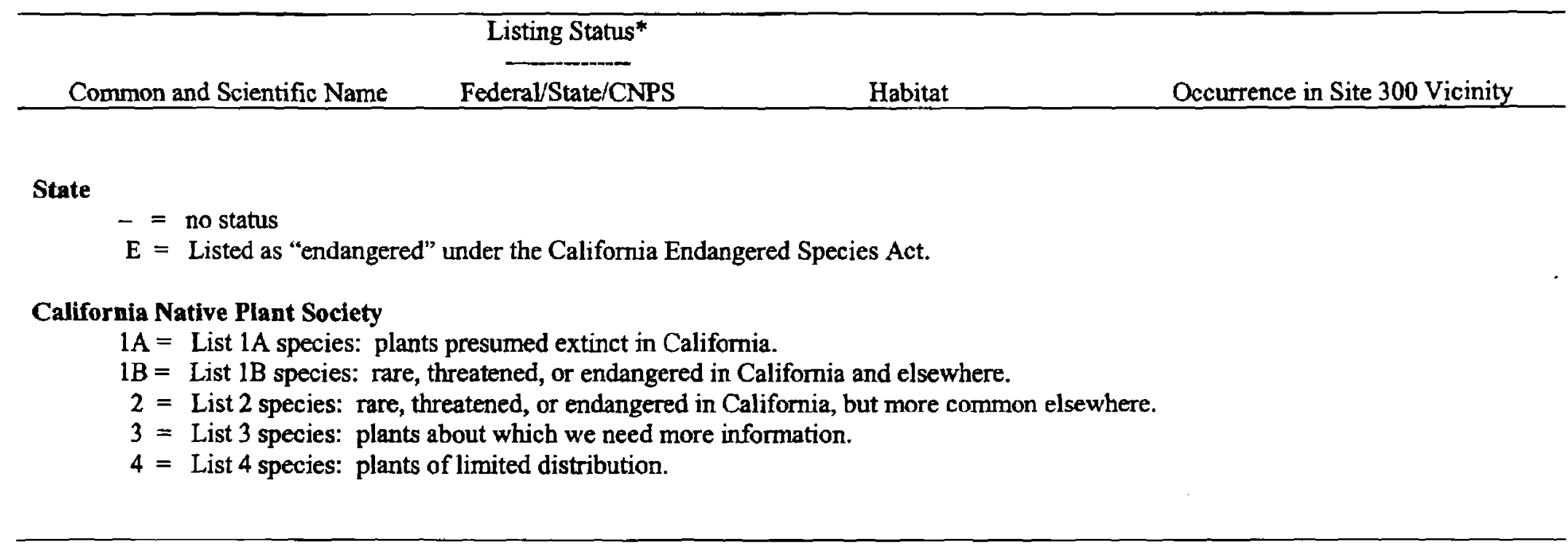


species-rich, although comparable data from other grassland sites is not generally available. At the Carnegie State Vehicle Recreation Area, on the south side of Corral Hollow, 352 plants were found in a 1,320-hectare site (Jones \& Stokes 2000). In contrast, only 209 plants were found in a 4,000-hectare study area in the central interior South Coast Ranges (Jones \& Stokes 2001), an area much more arid than that in which Site 300 occurs. In a grassland study area in the Sierra Nevada foothills, 287 plants were found on a site similar in size to Site 300 (Jokerst 1983).

The lists of plants reported by BioSystems (1986b) and compiled during this survey are largely congruent. In the Site 300 checklist, 261 plants are reported both by BioSystems and Jones \& Stokes. Sixty-four plants are reported by BioSystems alone, and 81 plants are reported by Jones \& Stokes alone. A substantial number of the plants uniquely reported by BioSystems or Jones \& Stokes may be due to disagreements on species identities. For example, BioSystems (1986a) reported "Boisduvallia glabra [sic]" (synonym of Epilobium pygmaeum) from vernal pools on Site 300 , whereas Jones \& Stokes observed only E. cleistogamum in the vernal pools.

The differences observed between surveys conducted in different years illustrates the importance of conducting multi-year surveys when developing a local flora. Year-to-year variation in environmental parameters, particularly the amount and timing of rainfall, may have a substantial effect on whether or not species are evident. A species dependent on above-normal rainfall for germination might be present in the seed bank but it would not be evident during most years. In addition, local floras change over time, with species dispersing into an area and becoming established and others becoming locally extinct. For example, stinkweed (Dittrichia graveolens), which appears to have been introduced into the south San Francisco Bay area about 20 years ago (Preston 1997) and has since spread outwards along roadsides into the Sacramento-San Joaquin delta and the Central Valley, is now established at Site 300 . Other species at Site 300 , such as diamondpetaled poppy and large-flowered fiddleneck, are in danger of extinction both locally and globally.

A second aspect in developing a local flora is seasonal variation within a year. Ideally, a floristic survey is carried out during the full course of the growing season (which, in central California, can be 365 days long). In practice, most floristic surveys are done during the period when the majority of species would be evident or when particular target species would be evident. The Site 300 surveys were scheduled to coincide with the period when special-status species would be evident; the survey window set by this parameter limits the amount of information that can be gathered about the flora as a whole, and the size of the survey window is further limited by the information available about the potential target species. BioSystems (1996b) terminated their rare plant survey in May, and many of the species observed by Jones \& Stokes but not BioSystems were species that bloom mid-summer or later.

The differences in the lists developed during the current and previous surveys reflect several factors, including environmental variation, the timing of the surveys, and the general principal that the number of species observed increases with the time expended searching and the size of the area surveyed. Of the species 
blooming in early spring, Jones \& Stokes uniquely observed about an equal number of plants, as did BioSystems. This results suggests that at Site 300, these "unique" species are either very uncommon, highly localized, or may not be present every year, due to drought or some other factor unfavorable to their germination or growth. Certainly, additional surveys are likely to detect species that have not yet been recorded at Site 300 . The question remains: were these surveys adequate to detect all special-status species and their occurrences at Site 300? The fact that both early- and late-blooming species were detected and mapped at Site 300 indicates that the surveys covered the period when specialstatus plants would be evident and identifiable. On the other hand, the fact that "unique" species were detected during each survey indicates that there could be other uncommon, highly localized populations that were not detected, including special-status species.

\section{Special-Status Plant Species}

Fifty special-status species have been recorded in the general vicinity (within 1520 miles) of Site 300 (Table A-1). This is not surprising, as the Mount Diablo and Mount Hamilton Ranges are well-known centers of endemism in California (Raven and Axelrod 1978). Potential habitat for 28 of these species occurs on Site 300. As noted above, large-flowered fiddleneck, gypsum-loving larkspur, and big tarplant were previously recorded from Site 300 . Historic collections of several special-status species are known from sites close to Site 300: showy madia (Corral Hollow), caper-fruited tropidocarpum (near Midway), diamond-petaled poppy (Corral Hollow), Mount Diablo buckwheat (Corral Hollow), big tarplant (Midway, Tesla/Corral Hollow Road summit), and round-leaved filaree (Erodium macrophyllum) (Corral Hollow, Altamont Pass) (California Natural Diversity Data Base 2002).

Jones \& Stokes observed eight special-status plants on Site 300: large-flowered fiddleneck, big tarplant, diamond-petaled poppy, round-leaved filaree, gypsumloving larkspur, California androsace, stinkbells, and hogwallow starfish (Figures A-2 and A-3). California Native Species survey forms completed for each occurrence are appended to this report (Appendix A-2).

\section{Large-Flowered Fiddleneck}

\section{Findings}

We did not observe any new populations of large-flowered fiddleneck. We visited the Drop Tower population and the adjacent experimental population to observe the plants' phenology, but did not otherwise disturb them. The plants were observed in full bloom during our 2002 survey. The other two fiddleneck species at Site 300 that have large flowers, Eastwood's fiddleneck (Amsinckia eastwoodiae) and devil's lettuce (A. tessellata), were also in bloom during the surveys but could readily be distinguished from large-flowered fiddleneck by the nutlet morphology. We searched for, but were unable to locate, the second, smaller 

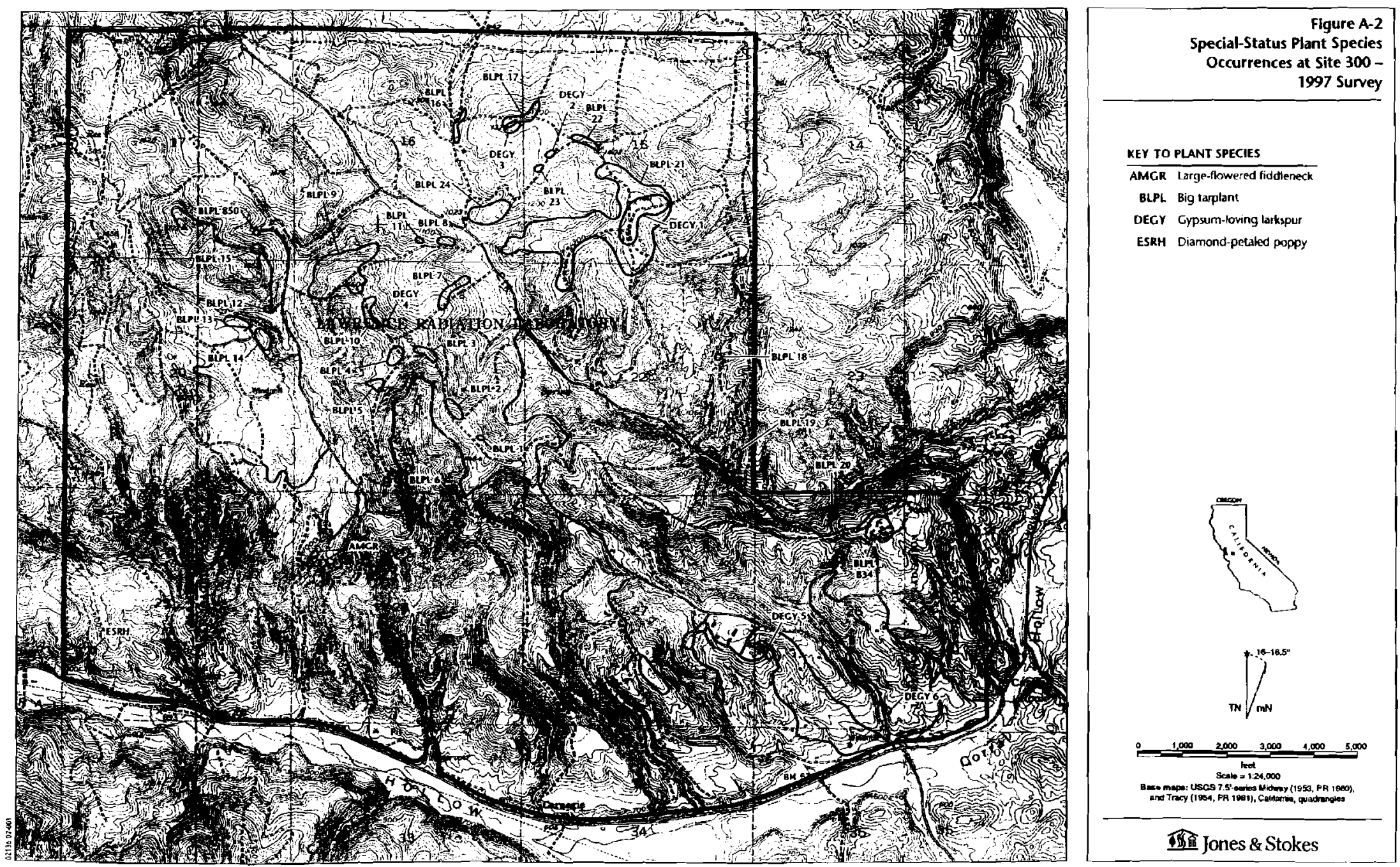


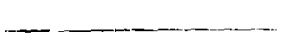

(...- 

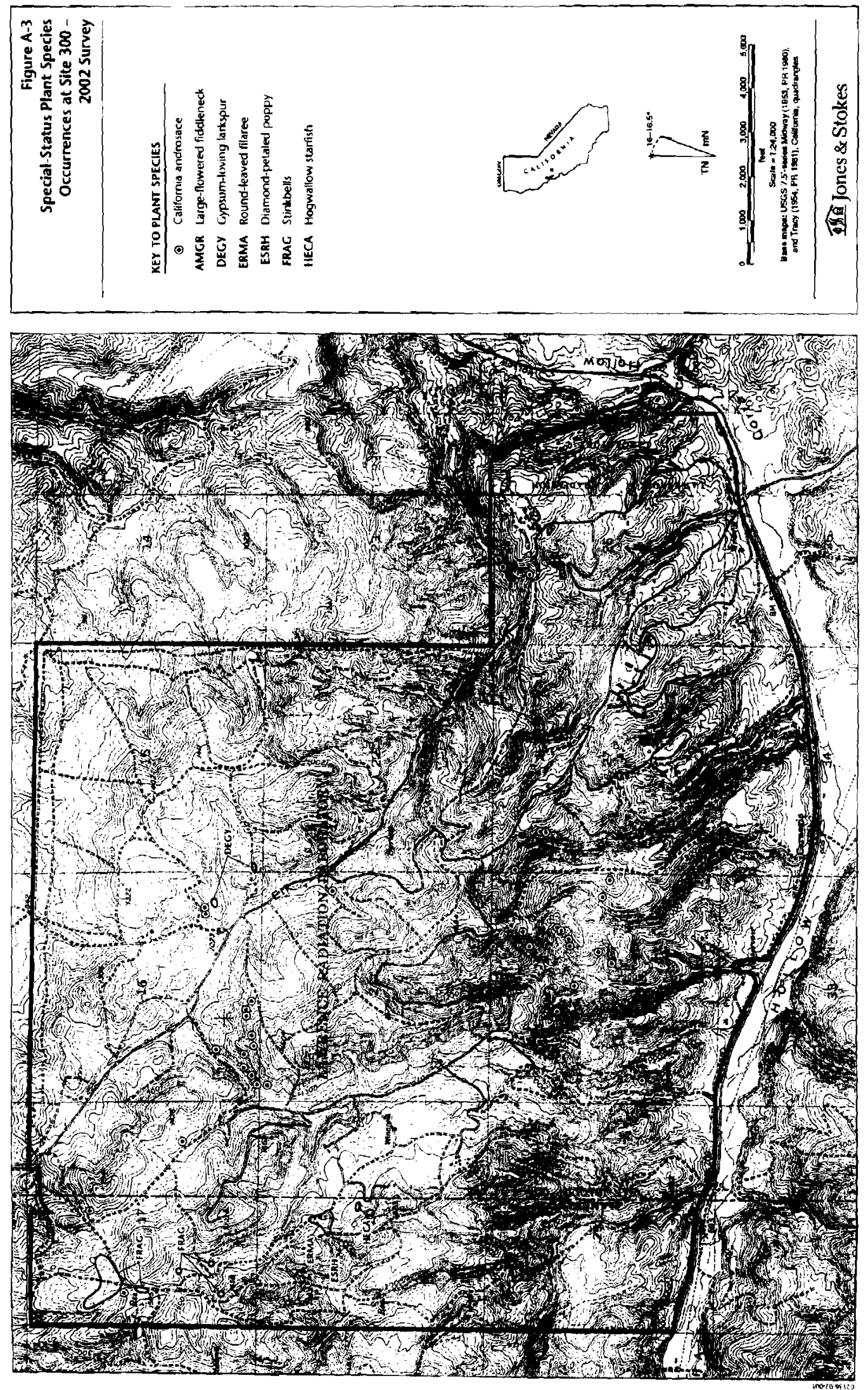

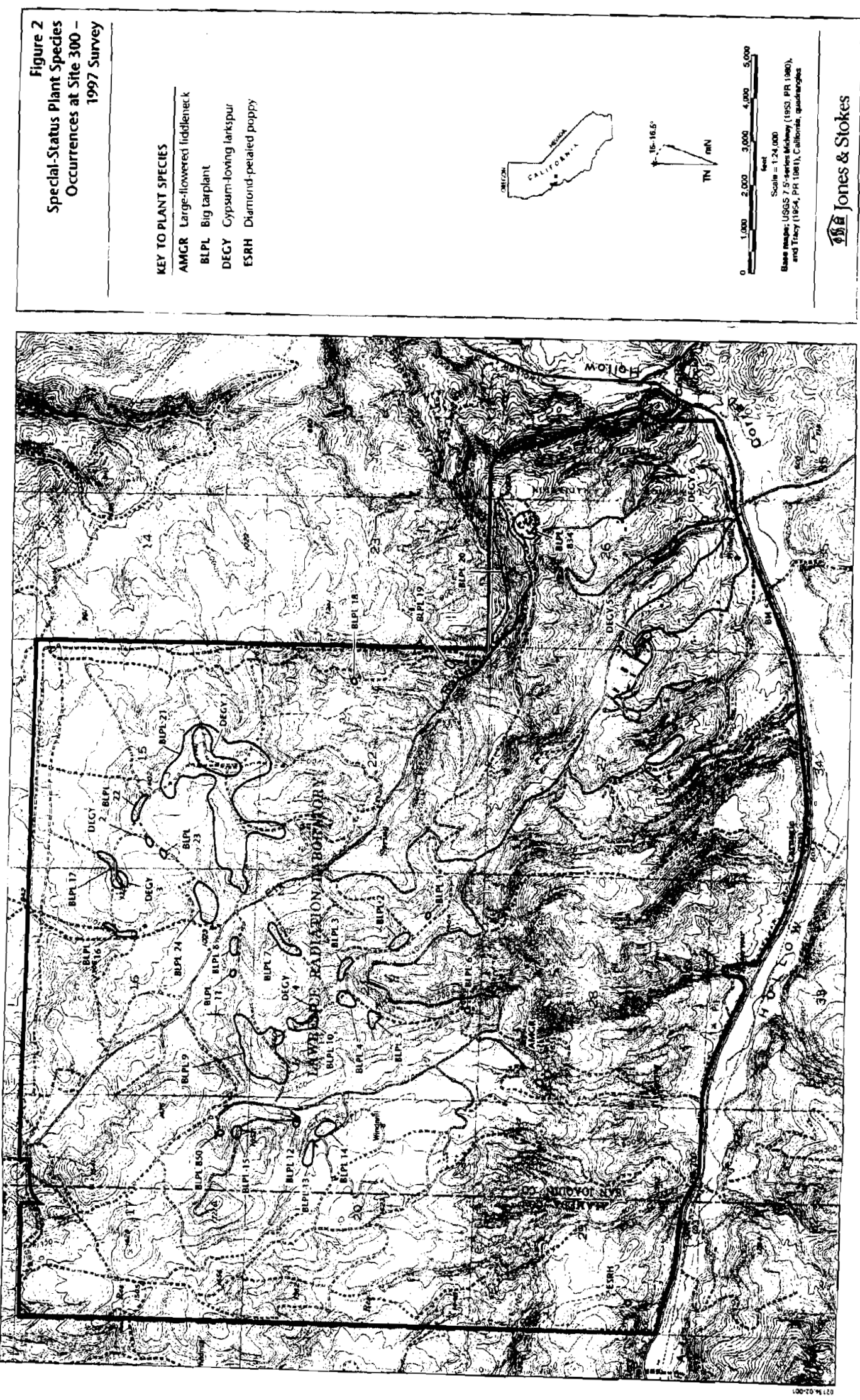
Table 2. 1997 Census of Blepharizonia plumosa localities at Site 300.

\begin{tabular}{|c|c|c|c|}
\hline Location & $\begin{array}{c}\text { Estimated } \\
\text { Number of Plants }\end{array}$ & $\begin{array}{l}\text { Aerial Extent of Population } \\
\text { (Hectares) }\end{array}$ & $\begin{array}{c}\text { Plant Density } \\
\text { (Plants/Hectare) }\end{array}$ \\
\hline 1 & 20 & 0.06 & 333 \\
\hline 2 & 500 & 1.82 & 275 \\
\hline 3 & $8,900^{a}$ & 0.89 & 10,000 \\
\hline 4 & 200 & 1.30 & 154 \\
\hline 5 & $5,900^{\circ}$ & 0.59 & 10,000 \\
\hline 6 & 500 & 0.30 & 1,667 \\
\hline 7 & 100 & 1.05 & 95 \\
\hline 8 & 250 & 0.57 & 438 \\
\hline 9 & $52,850^{a}$ & 10.57 & 5,000 \\
\hline 10 & $5,050^{\circ}$ & 1.01 & 5,000 \\
\hline 11 & 50 & 0.34 & 147 \\
\hline 12 & 300 & 0.40 & 750 \\
\hline 13 & $5,250^{\circ}$ & 1.05 & 5,000 \\
\hline 14 & $3,600^{*}$ & 1.80 & 2,000 \\
\hline 15 & 100 & 0.46 & 217 \\
\hline 16 & 150 & 0.82 & 183 \\
\hline 17 & 500 & 0.69 & 725 \\
\hline 18 & 150 & 0.08 & 1,875 \\
\hline 19 & 250 & 0.16 & 1,562 \\
\hline 20 & $12,060^{a}$ & 12.06 & 1,000 \\
\hline 21 & $34,640^{\prime}$ & 34.64 & 1,000 \\
\hline 22 & $8,900^{\circ}$ & 0.89 & 10,000 \\
\hline 23 & 200 & 0.20 & 1,000 \\
\hline 24 & $4,648^{b}$ & 2.14 & 2,172 \\
\hline B834 & $300^{c}$ & 4.15 & 29 \\
\hline B850 & $100^{c}$ & 0.08 & 500 \\
\hline Totals & 145,468 & 78.15 & \\
\hline
\end{tabular}

"Number of individuals based on density estimate multiplied by aerial extent of population. All other estimates based on direct counts.

'Number of individuals partially based on direct count and partially based on density estimatc.

'Estimated in October, 1996. 
population ("Draney Canyon population"). This population appears to have been eliminated by an erosion event (Carlsen et al. 1998).

\section{Discussion}

With the completion of Jones \& Stokes' sitewide survey, all portions of Site 300 have been thoroughly surveyed for large-flowered fiddleneck. No additional populations have been located on the site. Based on the results of this and previous surveys, no further surveys appear to be warranted for large-flowered fiddleneck. Because the Drop Tower population and the adjacent experimental population are managed for their protection, no adverse impacts of operations at Site 300 on largeflowered fiddleneck are anticipated.

\section{Big Tarplant}

\section{Findings}

We mapped big tarplant at 26 localities on Site 300 in 1997 (Figure A-2). The number of plants at each locality varied from 20 to estimates of more than 50,000 (Table A-2). Most of the localities occupied less than 2 hectares, but two localities occupied more than 10 hectares, and the largest occupied more than 34 hectares. The distribution of plants at each locality varied; in some locations plants occurred in small patches scattered over a large area, while at other locations plant density was high and relatively uniform over a large area. Whether these localities represent different populations or subpopulations of one or more populations cannot be determined without further ecological and genetic investigations. Our estimate of 145,468 plants at Site 300 was conservative; the actual number may have been larger. In addition, several hundred to several thousand plants occurring sporadically along roadsides and in disturbed areas were observed but not included in the mapping and census.

\section{Discussion}

Big tarplant is not listed by the U.S. Fish and Wildlife Service (USFWS) or DFG. The rarity of the species was only recently recognized, and big tarplant was not included in CNPS's Inventory until the Fifth edition (Skinner and Pavlik 1994). It is considered to be a List IB species by CNPS (California Native Plant Society $2001 b)$. List $1 B$ species meet the definition of rare or endangered species under Section 15380 (d) of the CEQA guidelines and are typically addressed during CEQA reviews.

Big tarplant was described in 1873 by Dr. Albert Kellogg (Kellogg 1873). Two Blepharizonia species are currently recognized, B. plumosa and B. laxa (Baldwin et al. 2001). Blepharizonia plumosa has the more limited range, occurring only in Contra Costa, San Joaquin, and Stanislaus Counties (California Native Plant Society 200lb). Blepharizonia laxa, which ranges from Contra Costa County 
south to Kern County, also occurs at Site 300 but at fewer locations and in smaller numbers. Until recently, $B$. plumosa was known primarily from herbarium specimens collected at 11 locations. Of the specimens housed at the Jepson Herbarium and University of California Herbarium at U.C. Berkeley and at the California Academy of Sciences, most of the collections were made in or before 1937. Collections were made twice in 1975 , from near Tesla Summit and the mouth of Del Puerto Canyon, and in 1978 near Byron. In 1979, a population was discovered at Contra Loma Regional Park, south of Antioch (Knight pers. comm.). The status of this population is unknown (Edwards pers. comm.), and Lake (1993) notes that surveys conducted by the East Bay Regional Park District in 1991 were unable to locate the species.

In 1994, several more populations were discovered in Contra Costa County. Four small populations were discovered on private property southwest of Brentwood (California Natural Diversity Database 2002). Another population was found at Chaparral Springs, a new addition to Mount Diablo State Park (Ertter pers. comm.).

After our discovery of big tarplant at Site 300 in 1996, we searched for more populations in the vicinity of Site 300 , including visits to several historical localities. We discovered two new localities along Corral Hollow, including a population on a hillside south of the confluence of Elk Ravine and Corral Hollow and another population on a roadside bank about 0.3 kilometers east of the Corral Hollow /Tesla Road summit. We also relocated two historic populations. The first was on the south side of Tesla Road, about 1 kilometer east of the summit. This is CNDDB occurrence number 6, which is based on a specimen collected in 1933 by David Keck. According to Edwards (pers. comm.), this population was visited at an unspecified later date. Edwards gave the location as "near the small seep along Tesla Road, east of the summit." However, we found the population near the small seep to be $B$. laxa and that the population of $B$. plumosa was about 0.2 kilometer north of the seep. Therefore, it is uncertain whether the actual $B$. plumosa locality had been revisited since the original collection.

Another historic CNDDB occurrence (number 5) located was a 1908 collection by McMurphy from "along railroad tracks, 6.5 miles west of Tracy." Three different sets of tracks are present west of Tracy, and uncertain of which tracks were the ones referred to, the CNDDB mapped the location as 2 miles east of Midway on the Southern Pacific tracks (California Natural Diversity Database 2002). We visited the locality specified by the CNDDB and found no Blepharizonia plants. However, we returned to Midway, which is approximately 6.5 miles west of Tracy, and found B. plumosa occurring in the fields west of Midway Road. It seems more likely that this is the correct location for this occurrence, as both the Southern Pacific and Western Pacific tracks pass within 0.5 mile of this population.

We visited Contra Loma Regional Park to search for the population reported there. We were unable to locate any Blepharizonia plants at that location, but we did collect $B$. laxa less than 1 kilometer to the south, at Black Diamond Mines Regional Park.

In 1998, two more populations of $B$. plumosa were located during surveys at the proposed expansion to the Carnegie State Vehicle Recreation Area, adjacent to 
Table A-2. 1997 Census of Blepharizonia plumosa Localities at Site 300.

\begin{tabular}{|c|c|c|c|}
\hline Location & $\begin{array}{c}\text { Estimated Number } \\
\text { of Plants }\end{array}$ & $\begin{array}{c}\text { Aerial Extent of } \\
\text { Population (Hectares) }\end{array}$ & $\begin{array}{c}\text { Plant Density } \\
\text { (Plants/Hectare) }\end{array}$ \\
\hline 1 & 20 & 0.06 & 333 \\
\hline 2 & 500 & 1.82 & 275 \\
\hline 3 & $8,900^{2}$ & 0.89 & 10,000 \\
\hline 4 & 200 & 1.30 & 154 \\
\hline 5 & $5,900^{2}$ & 0.59 & 10,000 \\
\hline 6 & 500 & 0.30 & 1,667 \\
\hline 7 & 100 & 1.05 & 95 \\
\hline 8 & 250 & 0.57 & 438 \\
\hline 9 & $52,850^{2}$ & 10.57 & 5,000 \\
\hline 10 & $5,050^{a}$ & 1.01 & 5,000 \\
\hline 11 & .50 & 0.34 & 147 \\
\hline 12 & 300 & 0.40 & 750 \\
\hline 13 & $5,250^{2}$ & 1.05 & 5,000 \\
\hline 14 & $3,600^{2}$ & 1.80 & 2,000 \\
\hline 15 & 100 & 0.46 & 217 \\
\hline 16 & 150 & 0.82 & 183 \\
\hline 17 & 500 & 0.69 & 725 \\
\hline 18 & 150 & 0.08 & 1,875 \\
\hline 19 & 250 & 0.16 & 1,562 \\
\hline 20 & $12,060^{2}$ & 12.06 & 1,000 \\
\hline 21 & $34,640^{2}$ & 34.64 & 1,000 \\
\hline 22 & $8,900^{2}$ & 0.89 & 10,000 \\
\hline 23 & 200 & 0.20 & 1,000 \\
\hline 24 & $4,648^{b}$ & 2.14 & 2,172 \\
\hline B834 & $300^{c}$ & 4.15 & 29 \\
\hline B850 & $100^{c}$ & 0.08 & 500 \\
\hline Totals & 145,468 & 78.15 & \\
\hline \multicolumn{4}{|c|}{$\begin{array}{l}\text { Number of individuals based on density estimate multiplied by aerial extent of population. All other estimates } \\
\text { based on direct counts. } \\
\text { c Number of individuals partially based on direct count and partially based on density estimate. } \\
\text { Estimated in October, } 1996 \text {. }\end{array}$} \\
\hline
\end{tabular}


Site 300 (Jones \& Stokes 2000). That same year, seven more populations were discovered on private property proposed for a golf course and housing development, south of Antioch (California Natural Diversity Database 2002).

The recent discovery of new big tarplant occurrences, including the occurrences at LLNL Site 300 (the CNDDB regards the stands at Site 300 as separate occurrences), raises the known number of occurrences to 39 (California Natural Diversity Database 2002; Preston, unpublished data). Twelve of the CNDDB occurrences are located at Site 300 . Although locally common in the vicinity of Site 300 , the limited species distribution, small size of most of the existing occurrences, and threatened loss of habitat demonstrate that this taxon is quite rare and merits protection.

Big tarplant can be found at many locations on Site 300 . In 1997, most of the stands were in the northem half of Site 300 . However, monitoring of big tarplant at Site 300, initiated by LLNL ecologists in 1996, has found that stand location and size varies from year to year (Carlsen 2002). Although the cause of this variation is not clear, soil moisture availability is likely to be an important factor influencing big tarplant population dynamics. Big tarplant typically occurs on clay to clay-loam soils, which retain soil moisture longer than other soil types. In 1997, the locations having the highest densities and occupying the greatest area were on north-facing slopes, generally on the upper slope and ridgetop. North slopes receive less insolation than other slope aspects, which allows longer soil moisture retention. These locations often fall within the areas that are annually burned. Burning removes annual grasses that compete for available soil moisture and have been shown to accelerate soil moisture loss. These observations are generalities, however, and other factors are likely to play a role in the population dynamics.

The abundance of big tarplant on Site 300, particularly in burned areas, and its common occurrence in disturbed places suggest that site management practices have not adversely affected the populations at Site 300 . Some past activities, such as construction of fire roads and the test facilities in the northem half of Site 300, have eliminated small portions of big tarplant stands. The controlled burning does not appear to have an adverse long-term effect on the populations, as high plant densities were observed in 1997 in areas that are annually burned. However, intense fire does cause mortality. During our vegetation mapping in 2001, we observed numerous dead rosettes in an area that had been subjected to an intense burn. Monitoring of the populations has found that burns do cause mortality of big tarplant, but the effect of burns on the populations varies from year to year and site to site (Carlsen et al. 2002).

We recommend that LLNL continue its ecological studies of big tarplant to determine the best management strategy for the species. Documenting whether or not controlled burns are beneficial to big tarplant should be an important goal. The rarity of the species could potentially make it eligible for listing as endangered or threatened under the federal ESA. Currently, no threats are apparent that would indicate the need for listing in the near future.

Construction of new roads or facilities at Site 300 would have an adverse impact on big tarplant if done within the existing population(s) through direct removal of 
plants, excavation or burial of the seed bank, or habitat conversion (i.e., replacement of grassland by buildings and paved areas).

We recommend avoiding the existing stands to the extent feasible. We recognize that disturbance may have counteracting effects on big tarplant. Aside from the immediate effects on plants that are removed during ground-disturbing activities (such as maintaining fire trails), disturbed areas appear to serve as refugia and provide dispersal corridors for big tarplant at Site 300. More information is needed about the role of disturbance in the species' ecology.

LLNL's ecological studies could provide information on whether re-establishment or enhancement is feasible, if such measures become necessary.

\section{Diamond-Petaled Poppy}

\section{Flndings}

In 1997, we located a single population of diamond-petaled poppy, consisting of about 10 individuals, at the southwest corner of the site (Figure A-2). The population occupied less than 20 square meters. The population occurs on a northfacing slope at the narrow ecotone between annual grassland and the eroding bank face. Associated plant species included Poa secunda, Bromus madritensis subsp. rubens, Avena barbata, Stylomecon heterophylla, and Microseris douglasii.

In 2002, we located a second population of diamond-petaled poppy in the central western portion of Site 300 (Figure A-3). This population consisted of about 300 plants in an area of about 1,500 square meters. The population occurs on a westfacing bank in grassland dominated by Avena barbata, Bromus hordeaceus, and Poa secunda, in association with Stylomecon heterophyllum, Erodium cicutarium, Phlox gracilis, and Amsinckia lycopsoides. This population is more than 50 meters west of the nearest fire road and would not appear to be affected by any LLNL activities.

\section{Discussion}

Diamond-petaled poppy is not listed by USFWS or DFG. However, USFWS has designated the diamond-petaled poppy as a target for long-term conservation (U.S. Fish and Wildlife Service 1997), and its extreme rarity suggests that it should be considered for listing as endangered. Because the species had not been observed since 1950, the CNPS Inventory had placed the species on List 1A, presumed extinct (Skinner and Pavlik 1994). It is currently placed on List 1B (Califormia Native Plant Society 2001b).

Diamond-petaled poppy had been known to occur primarily in the eastern foothills of the Mount Hamilton and Diablo Ranges from Alameda County to Stanislaus County, with a disjunct occurrence in the Carrizo Plains in San Luis Obispo County (Ernst 1964). The species was reported from San Luis Obispo County in 
1988 , but the identification of plants from this location is disputed (California Natural Diversity Database 2002). The species was collected in 1993 from the Carrizo Plains by David Keil and again in 1995 by Curtis Clark (Clark 2000). The species was last reported from Corral Hollow by Peter Raven, who collected the species there in 1949 (California Natural Diversity Database 2002).

USFWS (1997) has recommended three Priority 1 tasks to be implemented for diamond-petaled poppy at Site 300. Priority 1 tasks are defined as actions "that must be taken to prevent extinction or prevent the species from declining irreversibly in the foreseeable future." These tasks involve censusing and monitoring the population at Site 300 and collecting seeds for banking; developing and implementing a management plan for the population; and propagating diamond-petaled poppy in the greenhouse for reintroduction into historic habitat locations.

Monitoring of this population by LLNL ecologists shows that the population size varies from year to year (Carlsen et al. 2001, 2002). In addition to being difficult to detect, Clark (pers. comm.) suggests that the plants may only appear in years with conditions favorable to them. What these conditions are is unknown, but monitoring of the population by LLNL ecologists suggests that composition of the plant community, geographic location, annual rainfall pattern, and competitor interactions may play a role (Carlsen et al. 2002).

\section{Round-Leaved Filaree}

\section{Findings}

In 2002, we encountered a single population of round-leaved filaree in the central western portion of Site 300 , approximately 160 meters northeast of the diamondpetaled poppy population also discovered in 2002 (Figure A-3). The population consisted of about 200 individuals in an area of about 14,000 square meters. The population occurs on an east-facing slope in association with Avena barbata, Erodium cicutarium, Monolopia major, Phacelia ciliata, Lepidium nitidum, Amsinckia lycopsoides, Trifolium willdenovii, Triteleia laxa, and Achyrachaena mollis. All but two of the plants were observed in fire trails.

\section{Discussion}

Round-leaved filaree is not listed by USFWS or DFG. It is considered to be a List 2 species by CNPS (California Native Plant Society 2001). List 2 species also meet the definition of rare or endangered species under Section 15380 (d) of the CEQA guidelines, but they are more common outside of Califomia.

The CNDDB (California Natural Diversity Database 2002) reports 74 occurrences of round-leaved filaree, many of which are based on historical collections. Except for one, all occurrences are believed to be extant, although only seventeen 
occurrences have been documented in the previous 10 years (California Natural Diversity Database 2002).

Round-leaved filaree ranges from northern California, south into northern Mexico, and east to southern Utah (Taylor 1993). In California, it is known from scattered occurrences in the Great Valley, southern North Coast Ranges, San Francisco Bay Area, South Coast Ranges, Channel Islands, Transverse Ranges, and Peninsular Ranges (Taylor 1993, California Natural Diversity Database 2002). It most often occurs in foothill locations at elevations between 60 and 600 meters (200 and 2,000 ) feet, but is has been collected from locations as low as 10 meters ( 30 feet) and as high as 1,220 meters $(4,000$ feet $)$.

Very little is known about the ecological requirements of round-leaved filaree. The CNDDB records indicate that it generally occurs in grasslands on friable clay soils (California Natural Diversity Database 2002, California Native Plant Society 2001). Ian Gillespie, a graduate student at the University of California, Riverside, is currently researching the ecology of round-leaved filaree (Gillespie 2001).

The presence of round-leaved filaree primarily in the fire trails suggests that this disturbance has provided a benefit to the population at Site 300. The nature of this benefit is not clear but could range from uncovering buried, dormant seeds to providing a microsite free from competing nonnative grasses. The fire trails could also have an adverse effect if vehicle traffic on the trails destroys the plants before they can set seed. Lacking more information on the species ecology, we have no recommendations other than to avoid driving on the fire trails at this location between October 15 and May 15 and to consider initiating a monitoring program to determine the ecological requirements of the species and what effect maintenance of fire trails has on the population.

\section{Gypsum-Loving Larkspur}

\section{Findings}

In 1997, we located six stands of gypsum-loving larkspur (Figure A-2). Most of the stands occur on upper slopes (ridges or saddles) in perennial grassland. Associated species include Nassella pulchra, Poa secunda, Erodium cicutarium, Marah fabaceus, and Blepharizonia plumosa. Stand 1, near the microwave antennas, consisted of around 200 individuals. Stands 2 and 3, north of the 801 complex, had around 20 to 25 individuals each. Three individuals (Stand 4) were located on the ridge southwest of M-83. About 500 individuals were present in Stand 5, at roadside, east of Building 810 . This stand had a high plant density and was in annual grassland (brome grasses dominant) on a roadcut, which was atypical of the other localities on Site 300 . Stand 6, which was east of Route 2, north of the entrance station, had about 25 individuals. Stand 6 was one of the two populations reported in the $1992 \mathrm{EIR}$. We attempted to locate the second population reported in the $1992 \mathrm{EIR}$, south of the 827 complex, with no success, although suitable habitat is present. 
In 2002, we encountered gypsum-loving larkspur at two locations (Figure A-3). However, because the plants were at a very early stage of flowering, we did not attempt to census the stands or to delineate their extent.

\section{Discussion}

Gypsum-loving larkspur is not listed by USFWS or DFG. It is placed on List 4 by CNPS (2001). List 4 species are not considered to be rare or endangered but are uncommon enough to warrant monitoring. Impacts on List 4 species generally are not significant under the criteria used for analyzing impacts under the National Environmental Policy Act (NEPA) or CEQA. However, local public ordinances or resource agencies may define List 4 species as important biological resources, setting a threshold of significance that encompasses impacts on these species.

Gypsum-loving larkspur occurs in the foothills bordering the western edge and southern end of the San Joaquin Valley (Lewis and Epling 1954). The Site 300 occurrence, therefore, is at the extreme northern end of the species' range. Our observations indicate that the Site 300 stands are generally associated with perennial grassland where needlegrass (Nassella sp.) is present.

The 1986 rare plant survey (BioSystems 1986b) reported that gypsum-loving larkspur was found throughout the site on north-facing grassland habitats. The 1986 vegetation survey (BioSystems 1986a) reported gypsum-loving larkspur from 16 of 218 vegetation plots, including plots located in oak woodland. These observations suggest that BioSystems did not differentiate between the two whiteflowered larkspur taxa that occur on Site 300. A second pale-flowered larkspur, Delphinium hesperium ssp. pallescens, is common on Site 300 and occurs in annual grassland and oak woodland, typically on north-facing slopes. Monitoring of gypsum-loving larkspur by LLNL ecologists in the spring of 2000 confirmed that many of the stands reported at Site 300 are actually Delphinium hesperium ssp. pallescens (Carlsen et al. 2001).

Because gypsum-loving larkspur was in late flower and early fruit during our 1997 survey, it was evident and identifiable throughout Site 300. Although additional individuals could occur at scattered locations (e.g., Stand 4 and the two locations observed in 2002), additional extensive surveys for this species do not appear warranted. We recommend that these stands continue to be monitored periodically, due to the potential for the taxon's listing at some future time.

Past impacts on gypsum-loving larkspur at Site 300 have been the construction of fire roads through the populations and the construction of the microwave antennas in Stand 1. Fire roads on Site 300 often run on ridgetops, which appears to be where gypsum-loving larkspur mostly occurs. The timing of controlled burning may also affect the plants. A grass fire, sparked by a test shot on May 8, 1997, burned through Stands 1, 2, and 3. Most of the plants were developing fruits, and heat from the fire may have killed the developing seeds. We recommend that fire roads through the existing population(s) be maintained in their present positions and that no new fire roads be constructed through them. We also recommend that 
controlled burning not be conducted until after June 1 in the areas supporting gypsum-loving larkspur.

\section{Californla Androsace}

\section{Findings}

In 2002, we encountered California androsace at 37 locations scattered across Site 300 (Figure A-3). The plants occur on moss- or lichen-covered banks and rock outcrops on north-facing slopes, in association with Poa secunda, Trifolium willdenovii, Erodium cicutarium, and an assortment of annual grasses and forbs, including Athysanus pusillus, Crassula connata, Plantago erecta, Senecio vulgaris, and Claytonia parviflora.

\section{Discussion}

California androsace is not listed by USFWS or DFG. It is placed on List 4 by CNPS (2001b).

California androsace is primarily found in the dry, interior parts of California, from the San Francisco Bay area and San Joaquin Valley, south through the interior South Coast Ranges and into southern California (Cholewa and Henderson 1993). It is known from at least 55 collections, including scattered occurrences from the Sacramento Valley and from Siskiyou County (CalFlora 2000). California androsace was previously reported from Site 300 in the 1986 rare plant survey (BioSystems 1986b). At that time, California androsace was not well known and was not yet treated as a special-status species.

The Jepson Manual (Cholewa and Henderson 1993) treatment of Androsace indicates that California androsace occurs on dry, grassy slopes, although it is also reported to occur in various habitats ranging from grasslands to chaparral and coastal scrub to oak woodlands (California Native Plant Society 2001b). At Site 300 , it occurs in a relatively localized microhabitat within the grassland matrix, typically where vegetation cover is low and mesic conditions are present. At Site 300 , this microhabitat is generally found on and adjacent to moss-covered soil or rock outcrops on north-facing slopes.

Because California androsace occurs on rock outcrops and relatively steep slopes, the occurrences on Site 300 appear to have been relatively unaffected by construction of Site 300 facilities and fire trails. Burns are not likely to have a substantial adverse affect on the occurrences, because the plants bloom and set seed in early spring, before most fires occur, and because the low vegetation cover where the plants occur would support only a low-intensity fire that would be unlikely to destroy the seed bank.

Because California androsace is reasonably abundant and not threatened at this time, intensive monitoring of the species is not currently warranted. Periodic, 
limited monitoring of the locations where it has been identified would provide current information on abundance and distribution should the conservation status of the species change.

\section{Hogwallow Starfish}

\section{Findings}

In 2002, we encountered hogwallow starfish at a single location west of Building 851 (Figure A-3). It occurs in friable clay soils in perennial grassland, on a gentle, east-facing slope with Poa secunda, Amsinckia eastwoodiae, Achyrachaena mollis, Lasthenia minor, and Microsteris gracilis.

\section{Discussion}

Hogwallow starfish is not listed by USFWS or DFG. It is placed on List 4 by CNPS (2001b).

Hogwallow starfish is primarily found in the north and central portion of the Great Valley and the southem Sierra Nevada foothills, with reported occurrences in the Peninsular Ranges of San Diego County (Morefield 1993; CalFlora 2000). It is seldom collected, and only about 26 occurrences are known (CalFlora 2000). Hogwallow starfish was previously reported from Site 300 in the 1986 rare plant survey (BioSystems 1986b). At that time, it was not yet treated as a special-status species.

Hogwallow starfish occurs in moist areas on clay soils in grasslands and in the drying bottoms of vernal pools ("hogwallow" is an old term for vernal pool) (Morefield 1993; California Native Plant Society 2001b).

The hogwallow starfish occurrence at Site 300 is at a remote location and does not appear to have been affected by construction of Site 300 facilities. A fire trail cuts through the habitat and is likely to have removed that portion of the population. Burns are not likely to have a substantial adverse affect on the occurrence because the plants bloom and set seed in early spring, before most fires occur, and because the low vegetation cover where the plants occur would support only a low-intensity fire that would be unlikely to destroy the seed bank.

Hogwallow starfish is not threatened at this time, and although relatively few populations have been documented, it is believed to be relatively abundant statewide. The recognition of this plant as a special-status species will stimulate efforts to document known populations and to locate and document new occurrences. Intensive monitoring of the population at Site 300 is not currently warranted. Periodic, limited monitoring of the population would provide current information on abundance should the conservation status of the species change. 


\section{Stinkbells}

\section{Findings}

In 2002, we encountered stinkbells in five stands in the northwest comer of Site 300 (Figure A-3). These stands occur in areas of native grassland in association with Poa secunda, Nassella pulchra, Allium serra, Dichelostemma capitata, Chlorogalum pomeridianum, Viola pedunculata, and Sanicula bipinnata. The soils are heavy clay. The three smaller stands each had less than a dozen plants present. The stand just east of the large vernal pool had about 80 plants present. In the large stand, several hundred plants were present.

\section{Discussion}

Stinkbells is not listed by USFWS or DFG. It is placed on List 4 by CNPS (200lb).

Stinkbells is found at scattered locations in the Great Valley and Sierra Nevada foothills from Placer County to Fresno County and in the Coast Ranges from Mendocino County to San Luis Obispo County (Ness 1993; CalFlora 2000). Once known from only a few locations, the recognition of this species as rare prompted the discovery of a substantial number of new occurrences, so that this species is no longer considered rare. Stinkbells was previously located at Site 300 during the 1986 rare plant survey (BioSystems 1986b), although it was misidentified as Fritillaria biflora. Stinkbells have flowers that are greenish-white to yellow and that have an unpleasant odor (reminiscent of dead fish), whereas F. biflora have brown to yellowish-green flowers and lack an unpleasant odor (Ness 1993).

The stinkbells occurrences at Site 300 are in a remote location and have not been affected by construction of Site 300 facilities. A fire trail cuts through the habitat and is likely to have removed a portion of the largest stand. The stands are outside of the area that receives regular burns. However, burns would not likely have a substantial adverse affect on the occurrences because the plants bloom and set seed in early spring, before most fires occur, and because the lower vegetation cover where the plants occur would support only a low-intensity fire that would be unlikely to destroy the seed bank.

Stinkbells is not threatened at this time and is believed to be relatively abundant statewide. Intensive monitoring of the population at Site 300 is not currently warranted. Periodic, limited monitoring of the population would provide current information on abundance should the conservation status of the species change.

\section{Additional Recommendations}

Floristic surveys at Site 300 have demonstrated that eight special-status plants are present and that habitat for these species is scattered across the entire site. Each sitewide survey detected previously undocumented occurrences of special-status 
plants at Site 300, and it is likely that additional, undetected occurrences of specialstatus plants are present at Site 300 . Although transect surveys are an efficient method for identifying potential habitat and locating special-status species, 100 percent coverage of a site as large as Site 300 is not practical. In addition, some species only occur in substantial numbers in years with above-average rainfall, such as showy madia, which is known to have occurred historically in Corral Hollow near the site of Carnegie (California Natural Diversity Database 2002). However, it is highly unlikely that any large populations of special-status plants remain undetected at Site 300; any remaining undetected populations are likely to be small and in remote, less accessible areas, similar to the populations of largeflowered fiddleneck and diamond-petaled poppy. We believe that the existing surveys are adequate for most planning purposes at Site 300. Although additional occurrences of the special-status species identified at Site 300 or additional specialstatus species could be present at Site 300, additional sitewide special-status species surveys would not be the most efficient method for locating these occurrences. Instead, species-specific surveys that focus on microhabitats suitable for the species identified in Table A-1 (in general, areas with low cover of introduced annual grasses) would be most likely to detect these occurrences. Because of year-to-year variation in site conditions, which results in plants being evident some years but not in others, and because plants may disperse from one area to another, we recommend that site-specific surveys be conducted when any future activities that involve substantial ground disturbance, such as construction of new facilities, are planned. We recommend continued monitoring of the specialstatus plant populations present, in particular, large-flowered fiddleneck, diamondpetaled poppy, big tarplant, and round-leaved filaree. We also recommend that studies focus on the effects that burning the grasslands at Site $\mathbf{3 0 0}$ has on specialstatus plants. 


\section{Printed References}

Baldwin, B. G., R. E. Preston, B. L. Wessa, and M. Wetherwax. 2001. A biosystematic and phylogenetic assessment of sympatric taxa in Blepharizonia (Compositae-Madiinae). Systematic Botany 26: 184-194.

BioSystems Analysis, Inc. 1986a. Vegetation of Site 300, Lawrence Livermore National Laboratory, San Joaquin County, California. July 18, 1986. Santa Cruz, CA. Prepared for Science Applications International Corporation, Pleasanton, CA.

BioSystems Analysis, Inc. 1986b. A rare plant survey of Site 300, Lawrence Livermore National Laboratory, San Joaquin County, California. November 1986. Santa Cruz, CA. Prepared for Science Applications International Corporation, Pleasanton, CA.

CalFlora: Information on California plants for education, research and conservation. [web application]. 2000. Berkeley, California: The CalFlora Database [a non-profit organization]. Available: http://www.calflora.org/.

California Department of Fish and Game. 1984. Guidelines for assessing effects of proposed developments on rare and endangered plants and plant communities. Sacramento, CA.

California Department of Fish and Game. 2000. Guidelines for assessing effects of proposed developments on rare and endangered plants and plant communities. May 4, 1984, revised May 8, 2000. Sacramento, CA.

California Native Plant Society. 2001a. Electronic inventory of rare and endangered vascular plants of California, Version 1.5.1 (Data updated October 10, 2001). Sacramento, CA.

California Native Plant Society. 2001b. Inventory of rare and endangered plants of California (sixth edition). Rare Plant Scientific Advisory Committee, David P. Tibor, Convening Editor. California Native Plant Society, Sacramento, CA.

California Natural Diversity Database. 1996. RareFind (November 1, 1996 update). California Department of Fish and Game. Sacramento, CA.

Califomia Natural Diversity Database. 2002. RareFind 2, Version 2.1.2 (March 1, 2002 update). California Department of Fish and Game, Sacramento, CA.

Carlsen, T., E. Bissell, and B. Pavlik. 1998. Restoration of the large-flowered fiddleneck (Amsinckia grandiflora) at Lawrence Livermore National Laboratory Site 300, Project Progress Report: Fiscal Year 1998 (October 1997-September 1998). Lawrence Livermore National Laboratory, Livermore, CA. (UCRL-AR-131846). 
Carlsen, T., E. Espeland, and B. Pavlik. 1999. Restoration of the large-flowered fiddleneck (Amsinckia grandiflora) at Lawrence Livermore National Laboratory Site 300, Project Progress Report: Fiscal Year 1999 (October 1998-September 1998). Lawrence Livermore National Laboratory, Livermore, CA. (UCRL-AR-135516).

Carlsen, T., E. Espeland and A. Smith. 2001. Rare plant restoration and monitoring at Lawrence Livermore National Laboratory Site 300, Project Progress Report: Fiscal Year 2000 (October 1999-September 2000). Lawrence Livermore National Laboratory, Livermore, CA. (UCRL-AR-142408).

Carlsen, T., E. Espeland, and A. Smith. 2002. Rare plant restoration and monitoring at Lawrence Livermore National Laboratory Site 300, Project Progress Report: Fiscal Year 2001 (October 2000-September 2001). Lawrence Livermore National Laboratory, Livermore, CA. (UCRL-AR-142408-01).

Cholewa, A. F., and D. M. Henderson, 1993. Primulaceae. Pages 905-909 in J. C. Hickman (ed.), The Jepson manual: higher plants of California. Berkeley, CA: University of California Press.

Clark, C. 2000. The genus Eschscholzia: California poppies and their relatives. [Web Site]. Available at http://www.intranet.csupomona.edu/ jcclark/poppy/.

Emst, W. R. 1964. The Genus Eschscholzia in the south Coast Ranges of California. Madroño 17:281-294.

Gillespie, I. G. 2001. [Home page]. Available at http://student.uct.edu/ gillei01/.

Jokerst, J. D. 1983. The vascular plant flora of Table Mountain, Butte County, California. Madroño 30(Supplement): 1-18.

Jones \& Stokes. 2000. California Department of Parks and Recreation, Carnegie State Vehicle Recreation Area, General Plan Amendment, Environmental Impact Report. Draft. February. (J\&S 98-043). Sacramento, CA. Prepared for California Department of Parks and Recreation, Twin Cities District, Livermore, CA, and the Off-Highway Motor Vehicle Recreation Division, Sacramento, CA.

Jones \& Stokes. 2001. Results of the special-status plant and wildlife surveys conducted along the proposed Path 15 transmission line project in Fresno and Merced Counties. Sacramento, CA. Prepared for Pacific Gas and Electric Company, San Francisco, CA.

Kellogg, A. 1873. Description of new plants from the Pacific States. Proceedings of the California Academy of Sciences (First Series) 5(1):44-56.

Lake, D. 1993. Unusual and significant plants of Alameda and Contra Costa Counties. Califomia Native Plant Society, East Bay Chapter. 
Lewis, H. and C. Epling. 1954. A taxonomic study of California delphiniums. Brittonia 8:1-22.

Morefield, J. D. 1993. Hesperevax. Page 284 in J. C. Hickman (ed.), The Jepson manual: higher plants of California. Berkeley, CA: University of Califormia Press.

Ness, B. D. 1993. Fritillaria. Pages 1194-1196 in J. C. Hickman (ed.), The Jepson manual: higher plants of California. Berkeley, CA: University of California Press.

Preston, R. E. 1997. Dittrichia graveolens (Asteraceae), new to the California weed flora. Madroño 44(2): 200-203.

Raven, P. H., and D. I. Axelrod. 1978. Origin and relationships of the California flora. University of California Publications in Botany. Volume 72. University of California Press, Berkeley, CA.

Skinner, M. W., and B. M. Pavlik. 1994. Inventory of rare and endangered vascular plants of California, Fifth edition. California Native Plant Society Special Publication Number 1, Sacramento, CA.

Taylor, M. S. 1993. Erodium. Pages 672-673 in J. C. Hickman (ed.), The Jepson manual: higher plants of California. Berkeley, CA: University of California Press.

U.S. Department of Energy and University of California. 1992. Final Environmental Impact Statement and Environmental Impact Report for Continued Operation of Lawrence Livermore National Laboratory and Sandia National Laboratories, Livermore. DOE EIS/0157.

U.S. Fish and Wildlife Service. 1997. Draft recovery plan for upland species of the San Joaquin Valley, California. Region 1, Portland, OR.

\section{Personal Communications}

Aasen, Ken. Acting Regional Manager. California Department of Fish and Game, Sacramento, CA. October 12, 1995 - letter to Kenneth C. Zahn, Environmental Evaluations Group, LLNL.

Clark, Curtis. Professor. Biological Sciences Department, California State Polytechnic University, Pomona, CA. May 30, 1997 - E-mail.

Edwards, Stephen. Director. East Bay Regional Park District Botanical Garden, Tilden Park, Berkeley. October 3, 1996 - telephone conversation.

Ertter, Barbara. Collections Manager. University of California and Jepson Herbaria, Berkeley. October 3, 1996 - telephone conversation. 
Knight, Walter. Rohnert Park. October 3, 1996 - telephone conversation.

Medlin, Joel. Field Supervisor. U.S. Fish and Wildlife Service, Sacramento, CA. September 22, 1995 - letter to Kenneth Zahn, Environmental Evaluations Group, LLNL. 
Appendix A-1

Annotated Checklist of the Vascular Plants of Lawrence Livermore Laboratory Site $\mathbf{3 0 0}$ 


\section{Annotated Checklist of the Vascular Plants of Lawrence Livermore Laboratory Site $\mathbf{3 0 0}$}

This list was compiled from Jones \& Stokes (J\&S) site surveys performed in May and September, 1997, and March and April, 2002. It also incorporates species reported by BioSystems (BS) (1986). Nomenclature follows The Jepson Manual (Hickman 1993), except where noted. Synonyms [in brackets] are provided for plant names used in BioSystems' checklist that have been superceded. Common names generally are taken from The Jepson Manual or CalFlora (2000). Introduced species are preceded with an asterisk.

\section{Pterophyta (Ferns)}

\section{Pteridaceae (Brake Family)}

Pellaea andromedifolia (Kaulf.) Fee. At base of rocks in coastal scrub. Local, uncommon. Coffee fern. (BS, J\&S)

Pellaea mucronata (D. Eaton) D. Eaton. Bird's-foot fern. Rock outcrops in blue oak woodland. Uncommon. (J\&S)

Pentagramma triangularis (Kaulf.) G. Yatskievych, M. D. Wyndham, \& E. Wollenweber. Gold-back fern. Rock outcrops in blue oak woodland. Locally common. [Pityrogramma triangularis Kaulf.] (BS, J\&S)

\section{Coniferophyta (Conifers)}

\section{Cupressaceae (Cypress Family)}

Juniperus californica Hook. California juniper. Juniper woodland and scrub, juniper-oak woodland, and scattered in grasslands. Widespread, common. (BS, J\&S) 


\section{Anthophyta--Dicotyledones}

\section{Amaranthaceae (Amaranth Family)}

*Amaranthus albus L. Tumbleweed. Wetlands. Uncommon. (J\&S)

Amaranthus blitoides Wats. Prostrate amaranth. (BS)

Amaranthus californicus (Moq.) Wats. California amaranth. Wetlands.

Uncommon. (J\&S)

\section{Anacardiaceae (Sumac Family)}

Toxicodendron diversilobum (T. \& G.) Greene. Poison-oak. Poison-oak scrub. Local, in one stand on the west side of Site 300. (BS, J\&S)

\section{Apiaceae (Carrot Family)}

Apiastrum angustifolium Nutt. Wild celery. Blue oak woodland. Local, uncommon. (BS, J\&S)

Bowlesia incana Ruiz Lopez \& Pav. Bowlesia. At base of rocks in grasslands. Local, uncommon. (BS, J\&S)

Lomatium caruifolium (Hook. \& Arn.) Coult. \& Rose. Caraway-leaved lomatium. Grasslands. Widespread but uncommon. (BS, J\&S)

Lomatium utriculatum (T. \& G.) Coult. \& Rose. Common lomatium. Grasslands. Widespread but uncommon. (BS, J\&S)

Sanicula bipinnata Hook. \& Am. Poison sanicle. Blue oak woodland, coastal scrub. Widespread, common. (BS, J\&S)

Sanicula bipinnatifida Hook. Purple sanicle. Grasslands. Local, uncommon. (BS, J\&S)

Sanicula crassicaulis DC. Pacific sanicle. Elderberry scrub. Local, uncommon. (J\&S)

*Torilis nodosa (L.) Gaertner. Knotted hedge parsley. (BS)

Yabea microcarpa (Hook. \& Am.) Koso-Polj. California hedge-parsley. Blue oak woodland. Local, uncommon. (BS, J\&S) 


\section{Asclepiadaceae (Milkweed Family)}

Asclepias fascicularis Decne. Narrow-leaf milkweed. Grassland. Uncommon. (BS, J\&S)

\section{Asteraceae (Sunflower Family)}

Achillea millefolium L. Common yarrow. Grasslands, coastal scrub, blue oak woodland. Widespread, common. [var. californica (Pollard) Keck] (BS, $\mathrm{J} \& \mathrm{~S})$

Achyrachaena mollis Schauer. Blow-wives. Grasslands, vernal pool. Widespread but uncommon. (BS, J\&S)

Agoseris grandiflora (Nutt.) Greene. Large-flowered agoseris. Grassland. Local, uncommon. (BS, J\&S)

Agoseris heterophylla (Nutt.) Greene. Annual agoseris. Grasslands. Widespread but uncommon. (BS, J\&S)

Ancistrocarphus filagineus Gray. Woolly fishhooks. Bare soil in grasslands, coastal scrub. Local, uncommon. [Stylocline filaginea (Gray) Gray] (BS, $\mathrm{J} \& \mathrm{~S})$

Artemisia californica Less. California sage. Coastal scrub. Widespread, common. (BS, J\&S)

Baccharis pilularis DC. Coyote brush. Blue oak woodland, along drainage. Local, uncommon. [var. consanguinea (DC.) Kuntze] (BS, J\&S)

Baccharis salicifolius (Ruiz Lopez \& Pav.) Pers. Mule fat. Along stream channels. Local, uncommon. [B. viminea DC.] (BS, J\&S)

Blepharizonia laxa Greene. Viscid big tarplant. Grasslands, ruderal. Uncommon. [B. plumosa ssp. viscida Keck; see Baldwin et al. 2001 for nomenclature] (J\&S)

Blepharizonia plumosa (Kell.) Greene. Big tarplant. Grasslands, ruderal. Widespread, common (see Figure 2). List $1 B$ in CNPS Inventory. (J\&S)

*Carduus pycnocephalus L. Italian thistle. Grasslands. Widespread but uncommon. (BS, J\&S)

*Carduus tenuiflorus Curtis. Slender-flowered thistle. Wetlands, blue oak woodland. Common. (J\&S) 
Centromadia fitchii (Gray) Greene. Fitch's spikeweed. Ruderal. Local, uncommon. [Hemizonia fitchii Gray; see Baldwin 1999 for revised nomenclature] (J\&S)

Centromadia pungens (Hook. \& Arn.) Greene subsp. pungens. Common spikeweed. Grasslands, ruderal. Local, uncommon. [Hemizonia pungens (Hook. \& Arn.) T. \& G; see Baldwin 1999 for revised nomenclature] (J\&S)

*Centaurea melitensis L. Tocalote. Grasslands. Local, uncommon. (BS, J\&S)

${ }^{*}$ Centaurea solstitialis $\mathrm{L}$. Yellow star-thistle. Grasslands. Uncommon. (BS, $\mathrm{J} \& \mathrm{~S})$

* Chamomilla suaveolens (Greene) Rydb. Pineapple weed. Ruderal. Local, uncommon. (BS, J\&S) [Matricaria matricarioides (Less.) Porter]

*Cirsium occidentale (Nutt.) Jeps. ssp. venustum (Greene) Jeps. Venus thistle. Grassiands. Local, uncommon. [C. proteanum J. Howell] (BS, J\&S)

*Cirsium vulgare (Savi) Ten. Bull thistle. Freshwater seeps. Local, uncommon. (BS, J\&S)

Conyza canadensis (L.) Cronq. Horseweed. Wetlands, ruderal. Uncommon. (BS, J\&S)

Coreopsis calliopsidea (DC.) Gray. Leafy-stemmed coreopsis. (BS)

* Cynara cardunculus L. Artichoke thistle. Grasslands. Local, uncommon. (J\&S)

Deinandra kelloggii (Greene) Greene. Kellogg's tarplant. Grasslands, coastal scrub, ruderal. Common. [Hemizonia kelloggii Greene; see Baldwin 1999 for revised nomenclature] (BS, J\&S)

Deinandra lobbii (Greene) Greene. Lobb's tarplant. Coastal scrub. Common. [Hemizonia lobbii Greene; see Baldwin 1999 for revised nomenclature] (BS, J\&S)

*Dittrichia graveolens (L.) Greuter. Stinkweed. Ruderal. Local, uncommon. [not in The Jepson Manual; see Preston (1997)] (J\&S)

Ericameria linearifolia (DC.) Urb. \& J. Wussow. Interior goldenbush. Coastal scrub. Local, uncommon. (BS, J\&S)

Erigeron reductus (Cronq.) G. Nesom var. angustatus (Gray) G. Nesom. California rayless daisy. [E. inomatus Gray var. angustatus Gray] (BS)

Filago californica Nutt. California filago. Thin soils, coastal scrub. Widespread but uncommon. (BS, J\&S) 
*Filago gallica L. Narrow-leaved filago. Grasslands. Local, uncommon. [Logfia gallica Coss. \& Germ.] (BS, J\&S)

Gnaphalium californicum DC. California cudweed. Grasslands. Local, uncommon. (J\&S)

*Gnaphalium luteo-album L. Weedy cudweed. Along stream channel. Local, uncommon. (J\&S)

Gnaphalium palustre Nutt. Marsh cudweed. Vemal pool, freshwater seep. Local, uncommon. (BS, J\&S)

Grindelia camporum Greene. Great Valley gumplant. Grasslands, coastal scrub, blue oak woodland; Widespread, common. (BS, J\&S)

Gutierrezia californica (DC.) T. \& G. California matchweed. Coastal scrub, grasslands. Widespread, common. [G. bracteata Abrams] (BS, J\&S)

Helianthus annuus L. Common sunflower. Wetlands. Uncommon. (J\&S)

Hesperevax caulescens (Benth.) Gray. Hogwallow starfish. Grasslands, with moist, clay soils. One population (See Figure 2). CNPS List 4. [Evax caulescens Benth.] (BS, J\&S)

Hesperevax sparsiflora (Gray) Greene. Erect evax. [Evax sparsiflora Gray] (BS)

Heterotheca grandiflora Nutt. Telegraph weed. Rock outcrops in grassland. Uncommon. (J\&S)

Heterotheca sessiflora (Nutt.) Shinn. ssp. echioides (Benth.) Semple. Goldenaster. Grasslands. Uncommon. [H. echioides Benth.] (BS, J\&S)

Holocarpha obconica (Clausen \& Keck) Keck. San Joaquin tarplant. Grasslands, coastal scrub. Common. (BS, J\&S)

*Hypochaeris glabra L. Smooth cat's-ear. Grasslands. Widespread but uncommon. (BS, J\&S)

*Hypochaeris radicata L. Rough cat's-ear. Blue oak woodland, grasslands. Local, uncommon. (BS, J\&S)

*Lactuca serriola L. Prickly lettuce. Grassland. Common. (BS, J\&S)

Lagophylla ramosissima Nutt. Common hareleaf. Grassland, Common. (J\&S)

Lasthenia gracilis (DC.) Greene. California goldfields. Thin soil in grasslands, coastal scrub. Widespread but uncommon. [L. chrysostoma (Fisch. \& Mey.) Greene; recently segregated from $L$. californica Lindley by Chan (2001)] (BS, J\&S) 
Lasthenia microglossa (A. DC.) Greene. Small-rayed goldfields. Moist areas in grasslands. Widespread, common (BS, J\&S)

Lasthenia minor (A. DC.) Ornduff. Woolly goldfields. Grasslands. Widespread but uncommon. (BS, J\&S)

Layia gaillardioides (Hook. \& Am.) DC. Woodland layia. Grasslands. Widespread but uncommon. (BS, J\&S)

Layia platyglossa (Fisch. \& Mey.) Gray. Tidytips. Grasslands. Local, uncommon. (BS, J\&S)

Madia gracilis (Smith) Keck. Slender tarweed. (BS)

Malacothrix coulteri Gray. Snake's-head. Grasslands. Widespread but uncommon. (BS, J\&S)

Micropus californicus Fisch. \& Mey. Slender cottonweed. Grasslands. Local, uncommon. (BS, J\&S)

Microseris acuminata E. Greene. Needle microseris. Grasslands. Local, uncommon. (J\&S)

Microseris douglasii (DC.) Schultz-Bip subsp. douglasii. Douglas' microseris. Grasslands. Local, uncommon. (J\&S)

Microseris douglasii (DC.) Schultz-Bip subsp. tenella (Gray) Chambers. Small microseris. Grasslands. Local, uncommon. (BS, J\&S)

Monolopia major DC. Cupped monolopia. Grasslands. Widespread, common. (BS, J\&S)

Pentachaeta alsinoides Greene. Pentachaeta. Grassland. Local, uncommon. (BS, J\&S)

*Picris echioides L. Bristly ox-tongue. Freshwater seep. Local, uncommon. (BS, J\&S)

Psilocarphus brevissimus Nutt. Woolly marbles. (BS)

Psilocarphus tenellus Nutt. Slender woolly marbles. (BS)

Rafinesquia californica Nutt. California chicory. (BS)

Senecio breweri Davy. Brewer's butterweed. Blue oak woodland. Local, uncommon. (BS, J\&S)

*Senecio vulgaris L. Common groundsel. Grasslands, coastal scrub. Widespread, common. (BS, J\&S) 
*Silybum marianum (L.) Gaertner. Milk thistle. In stream channels.

Widespread but uncommon. (BS, J\&S)

Solidago canadensis $\mathrm{L}$. Canada goldenrod. (BS)

*Sonchus asper (L.) Hill. Prickly sow-thistle. Freshwater seeps. Uncommon. (BS, J\&S)

*Sonchus oleraceus L. Common sow-thistle. Ruderal. Widespread but uncommon. (BS, J\&S)

Stebbinsoseris heterocarpa (Nutt.) Chambers. Derived microseris. Grasslands. Uncommon. (J\&S)

Stephanomeria virgata Benth. var. pleurocarpa (Greene) Gottlieb. Tall stephanomeria. Grasslands. Uncommon. (J\&S)

Stylocline gnaphaloides Nutt. Everlasting nest straw. Rock outcrops in coastal scrub. Local, uncommon. (BS, J\&S)

*Taraxacum officinale Wigg. Common dandelion. (BS)

Uropappus lindleyi (DC.) Nutt. Silver puffs. Grasslands, coastal scrub. Widespread but uncommon. [Microseris lindleyi (DC.) Gray] (BS, J\&S)

Xanthium strumarium L. Common cocklebur. Freshwater seeps, along stream channels. Uncommon. [var. canadense (Miller) T. \& G.] (BS, J\&S)

\section{Boraginaceae (Borage Family)}

Amsinckia eastwoodiae J. F. Macbr. Eastwood's fiddleneck. Moist areas in grasslands. Widespread but uncommon. (J\&S)

Amsinckia grandiflora Gray. Large-flowered fiddleneck. Blue oak woodland. Restricted to a single population (see Figure 2). Federally-listed as endangered. (BS, J\&S).

Amsinckia lycopsoides Lehm. Tarweed fiddleneck. Grasslands, blue oak woodland. Widespread, common. (J\&S)

Amsinckia menzlesii (Lehm.) Nels. \& Macbr. var. intermedia (Fisch. \& Mey.) Ganders. Common fiddleneck. Grasslands, coastal scrub, blue oak woodland. Widespread, common. (BS, J\&S)

Amsinckia menziesii (Lehm.) Nels. \& Macbr. var. menziesii. Menzies' fiddleneck. Grasslands. Widespread but uncommon. (BS, J\&S) 
Amsinckia tessellata Gray var. tessellata. Devil's lettuce. Grasslands, oak woodland, coastal scrub. Widespread, common. (BS, J\&S)

Amsinckia vernicosa Hook. \& Am. Green fiddleneck. Clay barrens. Uncommon. (BS)

Cryptantha flaccida (Lehm.) Greene. Weak-stemmed cryptantha. Rock outcrops in grassland. Uncommon. (BS, J\&S)

Cryptantha intermedia (Gray) Greene. Common cryptantha. Rock outcrops in grassland. Uncommon. (BS, J\&S)

Cryptantha microstachys (Gray) Greene. Tejon cryptantha. (BS)

Heliotropium curassavicum L. Salt heliotrope. Freshwater seeps. Uncommon. [var. oculatum (Heller) Jtn.] (BS, J\&S)

Pectocarya penicillata (Hook. \& Am.) A. DC. Winged pectocarya. Coastal scrub. Widespread but uncommon. (BS, J\&S)

Plagiobothrys bracteatus (T. J. Howell) Jtn. Bracted popcom flower. Vernal pool. Local, uncommon. (J\&S)

Plagiobothrys canescens Benth. Soft popcom flower. Grasslands. Widespread, common. (BS, J\&S)

Plagiobothrys stipitatus (Greene) Jtn. var. micranthus (Piper) Jtn. Smallflowered popcorn flower. Vernal pool. Local, uncommon. (BS, J\&S)

Plagiobothrys tenellus (Nutt.) Gray. Grasslands. Local, uncommon. (BS, J\&S)

\section{Brassicaceae (Mustard Family)}

Athysanus pusillus (Hook.) Greene. Petty athysanus. Rock outcrops in grassland. Widespread but uncommon. (BS, J\&S)

${ }^{*}$ Brassica nigra (L.) Czernov. Black mustard. Grasslands. Uncommon. (BS, $\mathrm{J} \& S)$

*Capsella bursa-pastoris (L.) Medik. Shepherd's purse. Blue oak woodland. Widespread, common. (BS, J\&S)

*Cardaria pubescens (C. Meyer) Jarmol. White-top. (BS)

*Descurainia sophia (L.) Webb. Tansy mustard. Grasslands. Local, uncommon. (BS, J\&S) 
Erysimum capitatum (Dougl.) Greene. Western wallflower. (BS)

Guillenia flavescens (Hook.) Greene. Yellow-flowered guillenia. Grasslands. Local, uncommon. Flower color varies from pale yellow to lilac within Site 300. Hoover (1936) treated the lilac- to purple-flowered forms as Streptanthus lilacinus. [Caulanthus flavescens (Hook.) Pays.] (BS, J\&S)

Guillenia lasiophylla (Hook. \& Am). Greene. California mustard. Grasslands. Widespread, common. [Caulanthus lasiophyllus (Hook \& Arn.) Greene] (BS, J\&S)

*Hirschfeldia incana (L.) Lagr.-Foss. Mediterranean mustard. Grasslands, coastal scrub, ruderal. Widespread, common. [Brassica geniculata (Desf.) Ball] (BS, J\&S)

Lepidium nitidum (Nutt.) T. \& G. Shining peppergrass. Grasslands. Widespread, common. [var. insigne Greene] (BS, J\&S)

Nasturtium officinale $\mathrm{R}$. Br. Watercress. Freshwater seeps. Local, uncommon. [Rorippa nasturtium-aquaticum (L.) Hayek; see Al-Shehbaz \& Price (1998) for nomenclature] (BS, J\&S)

*Sinapis arvensis L. Charlock. Grasslands. Uncommon. (J\&S)

*Sisymbrium altissimum L. Tumble mustard. (BS)

*Sisymbrium officinale L. Hedge mustard. (BS)

* Sisymbrium orientale L. Oriental mustard. Outcrops in coastal scrub, grasslands. Locally common. (J\&S)

Tropidocarpum gracile Hook. Dobie pod. Grasslands. Widespread but uncommon. (J\&S)

Thysanocarpus curvipes Hook. var. curvipes. Lacepod. Blue oak woodland, grasslands. Widespread, common. (BS, J\&S)

Thysanocarpus curvipes Hook. var. elegans (Fisch. \& Mey.) Rob. Fringepod. Grasslands. Local, uncommon [T. elegans Fisch. \& Mey.] (BS, J\&S)

\section{Callitrichaceae (Water Starwort Family)}

Callitriche marginata Torr. California water-starwort. Vernal pool. Local, uncommon. (J\&S)

Callitriche verna L. Vernal water-starwort. (BS) 


\section{Campanulaceae (Bluebell Family)}

Downingia insignis Greene. Cupped downingia. Vernal pool. Local, uncommon. (BS, J\&S)

\section{Caprifoliaceae (Honeysuckle Family)}

Lonicera interrupta Benth. Chaparral honeysuckle. Along stream, in blue oak woodland. Local, uncommon. (BS, J\&S)

Sambucus mexicana C. Presl. Blue elderberry. Elderberry scrub, scattered along stream channels, or at base of rock outcrops. Local, uncommon. (BS, $\mathrm{J} \& \mathrm{~S})$

\section{Caryophyllaceae (Pink Family)}

${ }^{*}$ Cerastium glomeratum Thuill. Mouse-ear chickweed. Grasslands, coastal scrub. Local, uncommon. (BS, J\&S)

${ }^{*}$ Herniaria hirsuta L. ssp. cinerea (DC.) Cout. Gray herniaria. Coastal scrub. Widespread but uncommon. (BS, J\&S)

Loeflingia squarrosa Nutt. California loeflingia. (BS)

Minuartia californica (Gray) Mattf. California sandwort. Thin soils in coastal scrub. Local, uncommon (BS, J\&S)

Minuartia douglasii (T. \& G.) Mattf. Douglas' sandwort. (BS)

Sagina apetala Ard. Dwarf pearlwort. Rock outcrop in grasslands. Local, uncommon. (J\&S)

Sagina decumbens (Elliot) T. \& G. var. occidentalis (Wats.) G. Crow. Western pearlwort. (BS)

Silene antirrhina L. Snapdragon catchfly. Grasslands, coastal scrub. Uncommon. (BS, J\&S)

*Silene gallica L. Common catchfly. Grasslands, coastal scrub. Widespread but uncommon. (BS, J\&S)

Spergularia marina (L.) Griseb. Saltmarsh sand-spurry. (BS) 
*Stellaria media (L.) Villars. Common chickweed. Grasslands, blue oak woodland, coastal scrub. Widespread but uncommon. (BS, J\&S)

Stellaria nitens Nutt. Shining chickweed. Rock outcrops in grassland, coastal scrub. Widespread but uncommon. (BS, J\&S)

\section{Chenopodiaceae (Goosefoot Family)}

Atriplex patula L. Spear oracle. (BS)

*Atriplex rosea L. Tumbling oracle. Ruderal. Uncommon. (J\&S)

*Atriplex semibaccaua R. Br. Australian saltbush. Ruderal, grasslands. Local, uncommon. (BS, J\&S)

Atriplex serenana Nels. Bractscale. Ruderal. Uncommon. (J\&S)

*Chenopodium album L. Pigweed. Ruderal. Uncommon. (J\&S)

Chenopodlum californicum (Wats.) Wats. California goosefoot. Grasslands; uncommon. (BS, J\&S)

*Chenopodium murale L. Nettle-leaved goosefoot. Rock outcrops in grasslands. Uncommon. (J\&S)

Chenopodium rubrum L. Red goosefoot. (BS)

${ }^{*}$ Chenopodium vulvaria $\mathrm{L}$. Stinking goosefoot. (BS)

Monolepis nuttalliana (Schultes) Greene. Poverty weed. (BS)

*Salsola tragus L. Russian thistle. Grasslands, ruderal. Widespread, common. [S. kali L.] (BS, J\&S)

\section{Convolvulaceae (Morning-glory Family)}

*Convolvulus arvensis L. Field bindweed. Grasslands. Uncommon. (J\&S) 


\section{Crassulaceae (Stonecrop Family)}

Crassula connata (Ruiz Lopez \& Pav.) Berger. Pygmyweed. Rock outcrops in grasslands, coastal scrub. Widespread, common. [C. erecta (Hook. \& Arn.) Berger] (BS, J\&S)

\section{Cucurbitaceae (Gourd Family)}

Marah fabaceus (Naudin) Greene. California manroot. Grasslands.

Widespread, common. [var. agrestis (Greene) K. M. Stocking] (BS, J\&S)

\section{Euphorbiaceae (Spurge Family)}

Chamaesyce ocellata (Durand \& Hilg.) Millsp. Valley spurge. Grasslands. Uncommon. (J\&S)

Croton setigerus Hook. Turkey mullein. Grasslands, ruderal. Common. [Eremocarpus setigerus (Hook.) Benth.; see Webster (1992) for nomenclature] (BS, J\&S)

Euphorbia spathulata Lam. Reticulate-seeded spurge. Blue oak woodland. Local, uncommon. (BS, J\&S)

\section{Fabaceae (Pea Family)}

Astragalus asymmetricus E. Sheldon. Rattleweed. Grasslands. Widespread but uncommon. (BS, J\&S)

Astragalus didymocarpus Hook. \& Arn. Two-seeded milkvetch. Grassland, coastal scrub. Widespread but uncommon. (BS, J\&S)

Astragalus gambelianus E. Sheldon. Grasslands. Widespread but uncommon. (J\&S)

Lotus humistratus Greene. Hairy lotus. Grasslands, coastal scrub. Widespread but uncommon. (BS, J\&S)

Lotus wrangellianus Fisch. \& Mey. Chile lotus. Grasslands. Widespread, common. [L. subpinnatus Lagasca] (BS, J\&S) 
Lupinus albifrons Benth. Bush lupine. Blue oak woodland, coastal scrub. Widespread, common,. often dominant in small stands. (BS, J\&S)

Lupinus benthamii Heller. Spider lupine. Grasslands. Uncommon. (BS, J\&S)

Lupinus bicolor Lindley. Miniature lupine. Grasslands, coastal scrub, oak woodland. Widespread, common. [var. umbellatus (Greene) D. Dunn] (BS, $\mathrm{J} \& S)$

Lupinus microcarpus Sims var. densiflorus (Benth.) Jeps. Chick lupine. Grasslands, blue oak woodland. Widespread, common. [L. densiflorus Benth. var. aureus (Kell.) Munz and var. lacteus (Kell.) C.P. Smith] (BS, $\mathrm{J} \& S$ )

Lupinus microcarpus Sims var. microcarpus. Chick lupine. [L. densiflorus Benth. var. palustris (Kell.) C.P. Smith] (BS)

Lupinus succulentus Koch. Arroyo lupine. Grasslands. Widespread, common. (BS, J\&S)

*Medicago polymorpha L. California bur-clover. Grasslands. Widespread, common. (BS, J\&S)

*Melilotus alba Medik. White sweet-clover. Ruderal. Uncommon. (BS, J\&S)

*Melilotus indica (L.) All. Indian sweet-clover. Ruderal. Widespread but uncommon. (BS, J\&S)

Trifolium albopurpureum T. \& G. var. albopurpureum. Common Indian clover. Grasslands. Widespread but uncommon. (BS, J\&S)

Trifolium albopurpureum T. \& G. var. dichotomum (Hook. \& Am.) Isely. Branched Indian clover. [T. dichotomum Hook. \& Arn.] (BS)

Trifolium ciliolatum Benth. Tree clover. Grasslands. Local, uncommon. (J\&S)

Trifolium depauperatum Desv. var. amplectans (T. \& G.) L.F. McDermott. Pale sac clover. [T. amplectans T. \& G.] (BS)

Trifolium depauperatum Desv. var. truncatum (E. Greene) Isely. Narrowleaved sac clover. Grasslands. Local, uncommon. (J\&S)

Trifolium gracilentum T. \& G. Pinpoint clover. Grasslands, coastal scrub. Widespread, common. (BS, J\&S)

*Trifolium hirum All. Rose clover. Grasslands, ruderal. Local, uncommon. (J\&S)

Trifolium microcephalum Pursh. Small-headed clover. Grasslands. Local, uncommon. (J\&S) 
Trifolium microdon Hook. \& Arn. Valparaiso clover. (BS)

Trifolium oliganthum Steudel. Few-flowered clover. Coastal scrub. (BS)

Trifolium willdenovii Sprengel. Tomcat clover. Grasslands; coastal scrub, oak woodland. Widespread, common. [T. tridentatum Lindley] (BS, J\&S)

*Vicia sativa L. Common vetch, Grassland. Uncommon. (J\&S)

*Vicia tetrasperma (L.) Schreber. Slender vetch. (BS)

*Vicia villosa Roth ssp. varia (Host) Corbiere. Winter vetch. (BS)

*Vicia villosa Roth ssp. villosa. Hairy vetch. Grassland. Uncommon. (J\&S)

\section{Fagaceae (Beech Family)}

Quercus douglasii Hook \& Arn. Blue oak. Blue oak woodland, juniper oak woodland. Widespread, common. (BS, J\&S)

Quercus lobata Nee. Valley oak. Valley oak woodland, blue oak woodland. Local, uncommon. (BS, J\&S)

\section{Geraniaceae (Geranium Family)}

*Erodium botrys (Cav.) Bertol. Big heronbill. Grassland, coastal scrub.

Widespread, common. (BS, J\&S)

*Erodium brachycarpum (Godron) Thell. Heronbill. Grasslands. Widespread, uncommon. (BS, J\&S)

*Erodium cicutarium (L.) LHer. Red-stemmed filaree. Grasslands, coastal scrub, oak woodland. Widespread, common. (BS, J\&S)

Erodium macrophyllum Hook. \& Am. Round-leaved filaree. Grassland, on friable clay soil. Restricted to a single population (see Figure 2). CNPS List 2. (J\&S)

*Erodium moschatum (L.) L'Her. White-stemmed filaree. Grasslands. Local, uncommon. (BS, J\&S)

* Geranium dissectum L. Cut-leaf geranium. Grasslands. Uncommon. (J\&S) 
* Geranium molle L. Dove's-foot geranium. (BS)

\section{Grossulariaceae (Gooseberry Family)}

Ribes quercetorum Greene. Oak gooseberry. Elderberry scrub. Local, uncommon. (J\&S)

Ribes malvaceum Smith. Chaparral current. Elderberry scrub. local, uncommon. (BS, J\&S)

\section{Hippocastanaceae (Buckeye Family)}

Aesculus californicus (Spach) Nutt. California buckeye. Bluc oak woodland. Local, uncommon. (BS, J\&S)

\section{Hydrophyllaceae (Waterleaf Family)}

Emmenanthe penduliflora Benth. var. penduliflora. Whispering bells. Coastal scrub. Local, uncommon. (J\&S)

Eriodictyon californicum (Hook. \& Am.) Torr. Yerba santa. Coastal scrub. Local, uncommon. (BS, J\&S)

Nemophila menziesü Hook. \& Am. Baby blue-eyes. Grasslands. Local, uncommon. (BS, J\&S)

Nemophila pedunculata Dougl. Spreading nemophila. (BS)

Phacelia ciliata Benth. Great Valley phacelia. Grasslands. Widespread, common. (BS, J\&S)

Phacelia distans Benth. Common phacelia. Rock outcrops in grasslands, coastal scrub. Widespread, common. (BS, J\&S)

Phacelia douglesiï (Benth.) Torr. Douglas' phacelia. Coastal scrub. Local, uncommon. (BS, J\&S)

Phacelia imbricata Greene. Imbricate phacelia. Rock outcrops in grasslands, coastal scrub. Local, uncommon. (BS, J\&S)

Phacelia tanacetifolia Benth. Tansy phacelia. Rock outcrops in grasslands, coastal scrub. Widespread, common. (BS, J\&S) 
Pholistoma membranaceum (Benth.) Constance. White fiesta-flower. Blue oak woodland, base of rock outcrops in grasslands. Local, uncommon. (BS, J\&S)

\section{Lamiaceae (Mint Family)}

*Lamium amplexicaule L. Henbit. (BS)

*Marrubium vulgare L. Horehound. Coastal scrub, freshwater seep, nderal. Widespread but uncommon. (BS, J\&S)

*Mentha pulegium L. Pennyroyal. Freshwater seep. Local, uncommon. (J\&S)

Pogogyne serpylloides (Torr.) Gray. Thyme-like pogogyne. Elderberry scrub. Local, uncommon. (BS, J\&S)

Salvia columbariae Benth. Chia. Coastal scrub. Locally common. (BS, J\&S)

Salvia mellifera Greene. Black sage. Coastal scrub. Local, uncommon. (BS, $\mathrm{J} \& S)$

Stachys albens Gray. White hedgenettle. Freshwater seep. Local, uncommon. (BS, J\&S)

Trichostema lanceolatum Benth. Vinegar curls. Grasslands. Common. (BS, $\mathrm{J} \& \mathrm{~S})$

\section{Linaceae (Flax Family)}

Hesperolinon californicum (Benth.) Small. California dwarf flax. Grasslands. Uncommon. (BS, J\&S)

*Linum usitatissimum L. Common flax. Grassland, ruderal. Uncommon. $(\mathrm{J} \& \mathrm{~S})$

\section{Loasaceae (Loasa Family)}

Mentzelia affinis Greene. Hydra stick-leaf. Rock outcrops. Local, uncommon. (BS, J\&S) 
Mentzelia dispersa Wats. Small-flowered mentzelia. Rock outcrops in grasslands, coastal scrub. Local, uncommon. (J\&S)

\section{Malvaceae (Mallow Family)}

Eremalche parryi (Greene) Greene. Parry's mallow. Grasslands, on lower canyon slope. Local, uncommon. (BS, J\&S)

* Malva parviflora L. Cheeseweed. Blue oak woodland. Uncommon. (BS, J\&S)

Malvella leprosa (Ortega) Krapov. Alkali mallow. Freshwater seep, grasslands, ruderal. Uncommon. (BS, J\&S)

\section{Oleaceae (Olive Family)}

Forestiera pubescens Nutt. Desert olive. Along stream. Single stand on west side of Site 300. [F. neomexicana Gray] (BS, J\&S)

\section{Onagraceae (Evening Primrose Family)}

Camissonia boothil (Dougl.) Raven ssp. decorticans (Hook. \& Arn.) Raven. Shredding evening primrose. Coastal scrub. Local, uncommon. (BS, J\&S)

Camissonia contorta (Dougl.) Raven. Plains evening primrose. Coastal scrub. Local, uncommon. [Camissonia cruciata, an unpublished name based on Oenothera cruciata (Wats.) Munz] (BS, J\&S)

Camissonia graclliflora (Hook. \& Arn.) Raven. Slender-flowered primrose. Open area in grasslands. Local, uncommon. (BS, J\&S)

Camissonia hirtella (Greene) Raven. Hairy sun-cups. Coastal scrub. Widespread but uncommon. (BS, J\&S)

Camissonia intermedia Raven. Intermediate sun-cups. Coastal scrub. Local, uncommon. (J\&S)

Clarkia affinis H. Lewis \& M. Lewis. Clarkia. Blue oak woodland, grasslands. Common. (BS, J\&S)

Clarkia purpurea (Curtis) Nels. \& Macbr. ssp. purpurea. Purple clarkia. Grasslands. Uncommon. (BS, J\&S) 
Clarkia temblorensis Vasek. Temblor clarkia. Blue oak woodland. Uncommon. (BS, J\&S)

Clarkia unguiculata Lindley. Elegant clarkia. Blue oak woodland. Uncommon. (BS, J\&S)

Epilobium brachycarpum C. Presl. Panicled willow-herb. Grasslands. Uncommon. (BS, J\&S) [E. paniculatum T.\& G.]

Epilobium canum (Greene) Raven. California fuschia. Coastal scrub. Local, uncommon. [ssp. mexicana (C. Presl) Raven] (BS, J\&S)

Epilobium cleistogamum (Curran) P. Hoch \& Raven. Cleistogamous spike primrose. Vernal pool. Local, uncommon. (J\&S)

Epilobium pygmaeum (Speg.) P. Hoch \& Raven. Smooth spike-primrose. Vernal pool. (BS)

\section{Orobanchaceae (Broomrape Family)}

Orobanche californica Cham. \& Schldl. ssp. jepsonï (Munz) Heckard. Jepson's broom-rape. Coastal scrub. Local, uncommon. (BS, J\&S)

Orobanche uniflora L. Naked broom-rape. Grassland, parasitic on Saxifraga californica. Local, uncommon. [var. minuta (Suksd.) D. B. Achey] (BS, $\mathrm{J} \& \mathrm{~S})$

\section{Papaveraceae (Poppy Family)}

Eschscholzia californica Cham. California poppy. Grasslands. Widespread, common. (BS, J\&S)

Eschscholzia rhombipetala Greene. Diamond-petaled poppy. Grasslands. Restricted to two small occurrences (see Figure 2). CNPS List 1B. (J\&S)

Papaver californicum A. Gray. Fire poppy. Grasslands. Local, uncommon. (J\&S)

Platystemon californicus Benth. Cream cups. Grasslands. Widespread, common. (BS, J\&S)

Stylomecon heterophylla (Benth.) G. C. Taylor. Wind poppy. Moist areas in grasslands. Widespread, common. (BS, J\&S) 


\section{Plantaginaceae (Plantain Family)}

Plantago elongata Pursh. Annual coast plantain. [Plantago bigelovii Gray] (BS)

Plantago erecta E. Morris. California plantain. Grasslands, coastal scrub. Widespread, common. (BS, J\&S)

Plantago lanceolata L. English plantain. (BS)

\section{Platanaceae (Sycamore Family)}

Platanus racemosa Nutt. Western sycamore. (BS)

\section{Polemoniaceae (Phlox Family)}

Allophyllum divericatum (Nutt.) A.D. Grant \& V. Grant. Straggling gilia. (BS)

Eriastrum pluriflorum (Heller) Mason. Many-flowered eriastrum. Grasslands. Local, uncommon. (BS, J\&S)

Gilia capitata Sims ssp. staminea (Greene) V. Grant. Blue field gilia. Rock outcrops in coastal scrub. Widespread, common. (BS, J\&S)

Gilia clivorum (Jeps.) V. Grant. Many-stemmed gilia. Grasslands, coastal scrub. Widespread but uncommon. (J\&S)

Gilia tricolor Benth. Bird's-eye gilia. Grasslands. Widespread, common. (BS, J\&S)

Linanthus bicolor (Nutt.) Greene. Bicolored linanthus. Coastal scrub. Widespread, common (BS, J\&S)

Linanthus dichotomus Benth. Evening snow. Coastal scrub. (BS)

Navarretia nigelliformis Greene. Adobe navarretia. Grasslands. Uncommon. (BS, J\&S)

Navarretia pubescens (Benth.) Hook. \& Am. Downy navarretia. Grasslands. Uncommon. (J\&S)

Phlox gracilis Hook. Slender phlox. Moist areas in grasslands. Widespread, common. (BS, J\&S) 


\section{Polygonaceae (Buckwheat Family)}

Eriogonum angulosum Benth. Angle-stemmed buckwheat. Open areas in grasslands, coastal scrub. Widespread, common. (BS, J\&S)

Eriogonum fasciculatum Benth. var. polifolium (A. DC.) T. \& G. California buckwheat. Coastal scrub. Widespread, common. (BS, J\&S)

Eriogonum gracile Benth. Slender woolly wild buckwheat. Grasslands. Uncommon. (J\&S)

Eriogonum nudum Benth. var. pauciflorum Benth. Naked-stemmed buckwheat. Grassland. coastal scrub. Widespread, common. According to Professor James Reveal (pers. comm.), var. pauciflorum is a southern California entity, and the Eriogonum nudum from the Coast Ranges between Mount Diablo and Santa Barbara County may be an undescribed taxon. He suggested that we treat our material as var. pauciflorum until he is able to determine whether it is sufficiently distinct to warrant describing it as a new variety. (BS, J\&S)

Eriogonum wrightii Benth. var. subscaposum Wats. Wright's buckwheat. Coastal scrub. Local, uncommon. (J\&S)

Eriogonum wrightii Benth. var. trachygonum (Benth,) Jeps. Wright's buckwheat. (BS)

*Polygonum arenastrum Boreau. Common knotweed. (BS)

Pterostegia drymarioides Fisch. \& Mey. Pterostegia. At base of rock outcrops and under shrubs, in blue oak woodland, coastal scrub, and grasslands. Widespread, common. (BS, J\&S)

${ }^{*}$ Rumex conglomeratus Murray. Whorled dock. (BS)

*Rumex crispus L. Curly dock. Freshwater seep. Local, uncommon. (BS, $\mathrm{J} \& \mathrm{~S})$

Rumex salicifolius J. A. Weinm. var. denticulatus Torr. Willow dock. Freshwater seep. Local, uncommon. (BS, J\&:S)

\section{Portulacaceae (Purslane Family)}

Calandrinia ciliata (Ruiz Lopez \& Pav.) DC. Red maids. Grasslands, ruderal. Widespread, common. (BS, J\&S) 
Claytonia exigua T. \&. G. Common montia. Rock outcrops. Local, uncommon. [C. spathulata Dougl. var. exigua (T. \& G.) Robinson and var. tenuifolia (T. \& G.) Munz] (BS, J\&S)

Claytonia parviflora Hook. var. parviflora. Narrow-leaved miner's lettuce.

Blue oak woodland. Widespread but uncommon. (BS, J\&S)

Claytonia perfoliata Willd. Miner's lettuce. Blue oak woodland, coastal scrub. Widespread, common. (BS, J\&S)

Claytonia rubra (Howell) Tidestrom. Red miner's lettuce. Grasslands. Uncommon. (J\&S)

\section{Primulaceae (Primrose Family)}

Androsace elongata L. ssp. acuta (Greene) G. Robb. California androsace. Moss-covered rock outcrops and open areas in adjacent grassland. Widespread and common, but restricted to highly localized microhabitat sites (see Figure 2). CNPS List 4. (BS, J\&S)

Dodecatheon hendersonii Gray. Mosquito bills. Grasslands. Locally common. (BS, J\&S)

\section{Ranunculaceae (Buttercup Family)}

Delphinium gypsophilum Ewan ssp. gypsophilum. Gypsum-loving larkspur. Grasslands. Restricted to several occurrences along the east side of Site 300 (see Figure 2). CNPS List 4. (BS; J\&S)

Delphinium hesperium Gray. Western larkspur. (BS)

Delphinium hesperium Gray ssp. pallescens (Ewan) H. Lewis \& Epling. Pale western larkspur. Blue oak woodland, grasslands. Common. (J\&S)

Delphinium parryi Gray. Parry's larkspur. Blue oak woodland, grasslands. Common. (J\&S)

Delphinium patens Benth. Coastal scrub, oak woodland. Spreading larkspur. Widespread, common. (BS, J\&S)

Ranunculus canus Benth. Sacramento Valley buttercup. Grasslands. Local, uncormmon. [var. laetus (Greene) Benson] (BS, J\&S)

Ranunculus hebecarpus Hook. \& Arn. Pubescent-fruited buttercup. (BS) 
*Ranunculus muricatus L. Prickle-fruited buttercup. Wetlands. Uncommon. (J\&S)

Ranunculus sceleratus L. Celery-leaved buttercup. (BS)

\section{Rosaceae (Rose Family)}

Aphanes occidentalis (Nutt.) Rydb.. Western ladies'-mantle. Grasslands, oak woodland. Widespread but uncommon. (BS, J\&S)

Heteromeles arbutifolia (Lindley) Roemer. Toyon. Blue oak woodland. Local, uncommon. (BS, J\&S)

Prunus virginiana L. var. demissa (Nutt.) Torr. Westem choke-cherry. Elderberry scrub. Local, uncommon. (BS, J\&S)

Rubus leucodermis Torr. \& Gray. Blackcap raspberry. (BS)

Rubus ursinus Cham. \& Schldl. California blackberry. Elderberry scrub. Local, uncommon. (J\&S)

\section{Rubiaceae (Madder Family)}

Galium aparine $\mathrm{L}$. Common bedstraw. Blue oak woodland, grasslands. Widespread but uncommon. (BS, J\&S)

* Galium parisiense L. Wall bedstraw. Ruderal, grasslands. Widespread but uncommon. (J\&S)

Galium porrigens Dempster var. tenue (Dempster) Dempster. Climbing bedstraw. Blue oak woodland. Local, uncommon. (BS, J\&S)

\section{Salicaceae (Willow Family)}

Populus fremontii Wats. Fremont cottonwood. Fremont cottonwood riparian forest, valley oak woodland. Local, uncommon. (BS, J\&S)

Salix laevigata Bebb. Red willow. Great Valley willow scrub, Fremont cottonwood riparian forest. Local, uncommon. (BS, J\&S) 
Salix lesiolepis Benth. Arroyo willow. Great Valley willow scrub. Local, uncommon. (J\&S)

\section{Saxifragaceae (Saxifrage Family)}

Lithophragma affine Gray. Woodland star. (BS)

Lithophragma parviflorum (Hook.) Torrey \& A. Gray var. parviflorum. Moist areas in grasslands. Widespread, common. (J\&S)

Saxifraga callfornica Greene. California saxifrage. Moist areas in grasslands. Widespread, common. (BS, J\&S)

\section{Scrophulariaceae (Figwort Family)}

Castilleja attenuata (Gray) Chuang \& Heckard. Valley tassels. Grasslands. Local, uncommon. [Orthocarpus attenuatus Gray] (BS, J\&S)

Castilleja exerta (Heller) Chuang \& Heckard. Purple owl's-clover. Grasslands, coastal scrub, blue oak woodland. Widespread, common. [Orthocarpus purpurascens Benth.] (BS, J\&S)

Castilleja foliolosa Hook. \& Am. Ash-grey Indian paintbrush. Coastal scrub. Local, uncommon. (BS, J\&S)

Collinsia heterophylla Buist. Chinese houses. Blue oak woodland. Locally common. (BS, J\&S)

Collinsia sparsiflora Fisch. \& Mey. Few-flowered blue-eyed Mary. (BS)

Collinsia sparsiflora Fisch. \& Mey. var. collina (Jeps.) V. Newsom. Remoteflowered blue-eyed Mary. Rock outcrops and open, moist areas in grasslands. Widespread, common. (BS, J\&S)

Linaria canadensis (L.) Dum.-Cours. Blue toadflax. [L. texana Scheele] (BS)

Mimulus aurantiacus Curtis. Bush monkey flower. Elderberry scrub. Local, uncommon. (BS, J\&S)

Mimulus guttatus DC. Seep-spring monkey flower. Freshwater seep, vernal pool. Uncommon. [M. nasutus Greene] (BS, J\&S)

Mimulus latidens (Gray) Greene. Broad-toothed monkey flower. (BS) 
Scrophularia californica Cham. \& Schldl. California figwort. Rock outcrops in blue oak woodland, elderberry scrub. Local, uncommon. (BS, J\&S)

Veronica peregrina L. ssp. xalapensis (Kunth) Pennel. Purslane speedwell. Vernal pool. Local, uncommon. (BS, J\&S)

\section{Solanaceae (Nightshade Family)}

Datura wrightii Regel. Jimson weed. Ruderal, Great Valley willow scrub. Uncommon. (J\&S)

*Nicotiana acuminata Hook. var. multiflora (Philippi) Reiche. Many-flowered tobacco. Freshwater seep. Uncommon. (J\&S)

*Nicotiana glauca Graham. Tree tobacco. Along streams, Local, uncommon. (BS, J\&S)

Nicotiana quadrivalvis Pursh. Indian tobacco. [N. bigelovii (Torr.) Wats.] (BS)

Solanum americanum Miller. Small-flowered nightshade. Ruderal. Uncommon. [S. nodiflorum Jacq.] (BS, J\&S)

Solanum umbelliferum Eschsch. Blue witch. Grasslands. Uncommon. (BS, $J \& S)$

\section{Urticaceae (Nettle Family)}

Hesperocnide tenella Torr. Western nettle. Rock outcrops in grasslands, coastal scrub. Local, uncommon. (BS, J\&S)

Urtica dioica L. subsp. holosericea (Nutt.) Thorne. Hoary nettle. Freshwater seep. Local, uncommon. (BS, J\&S)

* Urtica urens L. Dwarf nettle. Ruderal, blue oak woodland. Local, uncommon. (BS, J\&S)

\section{Valerianaceae (Valerian Family)}

Plectritis brachystemon Fischer \& C. Meyer. Short-spurred plectritis. Moist areas in grasslands. Local, uncommon. (J\&S) 
Plectritis clliosa (Greene) Jeps. subsp. insignis (Susksd.) D. Morey. Longspurred plectritis. Blue oak woodland, grasslands. Widespread but uncommon. (BS, J\&S)

Plectritis congesta (Lindley) A. DC. Pink plectritis. (BS)

Plectritis macrocera Torrey \& A. Gray. White plectritis. Grasslands. Local, uncommon. (J\&S)

\section{Verbenaceae (Vervain Family)}

Verbena bracteata Lagasca \& J.D. Rodriguez. Prostrate vervain. Vemal pool. Local, uncommon. (J\&S)

\section{Violaceae (Violet Family)}

Vola pedunculata T. \&. G. Johnny jump-up. Grasslands. Local, uncommon. (J\&S)

Viola purpurea Kell. ssp. quercetorum (M. Baker \& J. Clausen) R. J. Little. Foothill violet. [V. quercetorum M. Baker \& J. Clausen] (BS)

\section{Viscaceae (Mistletoe Family)}

Phoradendron villosum (Nutt.) Nutt. Oak mistletoe. Blue oak woodland. Local, uncommon. (BS, J\&S)

\section{Vitaceae (Grape Family)}

Vitus californica Benth. California wild grape. Along stream in blue oak woodland. Local, uncommon. (J\&S) 


\section{Anthophyta--Monocotyledones}

\section{Cyperaceae (Sedge Family)}

Cyperus eragrostis Lam. Umbrella sedge. Vernal pool. Local, uncommon. (BS, J\&S)

Eleocharis macrostachya Britton. Creeping spikerush. Vernal pool. Local, uncommon. [E. palustris (L.) Roemer \& Schultes] (BS, J\&S)

Scirpus acutus Bigelow. Hard-stem bulrush. (BS)

Scirpus fluviatilis (Torr.) Gray. River bulrush. (BS)

\section{Iridaceae (Iris Family)}

Sisyrinchium bellum Wats. Blue-eyed grass. Grasslands. Local, uncommon. (J\&S)

\section{Juncaceae (Rush Family)}

Juncus balticus Willd. Baltic rush. Freshwater seep. Local, uncommon. (BS, $\mathrm{J} \& \mathrm{~S})$

Juncus bufonius L. Toad rush. Freshwater seep. Local, uncommon. (BS, J\&S)

Juncus occidentalis (Cov.) Wieg. Western rush. [Juncus tenuis Willd. var. congestus Engelm.] (BS)

Juncus oxymeris Engelm. Pointed rush. (BS)

Juncus patens E. Meyer. Spreading rush. Freshwater seep. Local, uncommon. (BS, J\&S)

Juncus xiphioides E. Meyer. Iris-leaved rush. Freshwater seep. Local, uncommon. (J\&S) 


\section{Juncaginaceae (Arrowgrass Family)}

Lilaea scilloides (Poiret) Hauman. Flowering quillwort. Vernal pool. Local, uncommon. (BS, J\&S)

\section{Lemnaceae (Duckweed Family)}

Lemna miniscula Herter. Least duckweed. [L. minuta Kunth] (BS)

\section{Liliaceae (Lily Family)}

Allium crispum Greene. Crinkled onion. Grasslands. Local, uncommon. (BS, $\mathrm{J} \& \mathrm{~S})$

Allium serra D. McNeal \& F. Ownbey. Serrated onion. Grasslands, blue oak woodland. Widespread, common. [A. serratum Wats.] (BS, J\&S)

Brodiaea elegans Hoover. Harvest brodiaea. Grasslands. Common. (BS, J\&S)

Calochortus clavatus Wats. ssp. pallidus (Hoov.) Munz. Mariposa lily. Grasslands. Uncommon. (BS, J\&S)

Calochortus venustus Benth. Mariposa lily. Grasslands. Uncommon. (BS, J\&S)

Chlorogalum pomerideanum (DC.) Kunth. Soap plant. Grasslands. Widespread, common (BS, J\&S)

Dichelostemma capitata Alph. Wood. Blue dicks. Grasslands, blue oak woodland. Widespread, common. Rolf Berg (1996) argues that this species should be treated as Dipterostemon capitatus (Benth.) Rydb. on the basis of its distinctive embryogenesis. [D. pulchellum (Salisb.) Heller] (BS, J\&S)

Fritillaria agrestis Greene. Stinkbells. Grasslands. Local, uncommon (see Figure 2). CNPS list 4. (BS, J\&S)

Trtteleia hyacinthina (Lindley) Greene. White hyacinth. Grasslands. Uncommon. (BS, J\&S)

Triteleia laxa Benth. Ithuriel's spear. Grasslands, blue oak woodland, coastal scrub. Widespread, common. (BS, J\&S) 


\section{Poaceae (Grass Family)}

Alopecurus carolinianus Walter. Carolina foxtail. Vemal pool. Local, uncommon. (J\&S)

Alopecurus saccatus Vasey. Pacific foxtail. Vernal pool. Local, uncommon. [A. howellii Vasey] (BS, J\&S)

* Avena barbata Link. Slender wild oat. Grasslands, coastal scrub, blue oak woodland. Widespread, common. (BS, J\&S)

*Avena fatua L. Wild oat. Grasslands. Widespread but uncommon. (BS, J\&S)

*Bromus arenarius Labill. Australian brome. Grasslands. Uncommon. (BS, J\&S)

Bromus carinatus Hook. \& Arn. California brome. Blue oak woodland, grasslands. Local, uncommon. [B. marginatus Steudel] (BS, J\&S)

*Bromus diandrus Roth. Ripgut brome. Grasslands, coastal scrub, blue oak woodland. Widespread, common. (BS, J\&S)

*Bromus hordeaceus L. Soft chess. Grasslands, coastal scrub, blue oak woodland. Widespread, common. [B. mollis L., B. molliformis Godron] (BS, J\&S)

*Bromus japonicus Murr. Japanese brome. (BS)

*Bromus madritensis L. subsp. madritensis. Foxtail chess. Grasslands, blue oak woodland. Widespread but uncommon. (BS, J\&S)

*Bromus madritensis L. subsp. rubens (L.) Husnot. Red brome. Grasslands, coastal scrub, blue oak woodland. Widespread, common. [B. rubens L.] (BS, J\&S)

${ }^{*}$ Bromus sterilis L. Poverty brome. (BS)

*Bromus tectorum L. Cheat grass. Grasslands. Uncommon. (BS, J\&S)

*Crypsis schoenoides (L.) Lam. Swamp timothy. Vernal pool. Local, uncommon. (J\&S)

*Cynodon dactylon (L.) Pers. Bermuda grass. Freshwater seep, ruderal. Local, uncommon. (J\&S)

Deschampsia danthonioides (Trin.) Benth. Annual hairgrass. Vernal pool. Local, uncommon. (BS, J\&S) 
Distichlis spicata (L.) Greene. Saltgrass. Grasslands, Freshwater seep. Local, uncommon. [var. stricta (Torr.) Beetle] (BS, J\&S)

Elymus elymoides (Raf.) Swezey. Squirreltail. [Sitanion hystrix (Nutt.) J. G. Smith] (BS)

Elymus glaucus Buckley. Blue wildrye. Oak woodlands. Local, uncommon. (BS, J\&S)

Elymus multisetus (J. G. Smith) Davy. Big squirreltail. Grasslands, blue oak woodland. Common. [Sitanion jubatum J. G. Smith] (BS, J\&S)

*Gestridium ventricosum (Gouan) Schinz \& Thell. Nitgrass. Grasslands. Local, uncommon. (J\&S)

Hordeum depressum (Scribner \& J. G. Smith) Rydb. Low barley. Swale in grasslands. Local, uncommon. (BS, J\&S)

*Hordeum marinum Hudson ssp. gussoneanum (Parl.) Thell. Mediterranean barley. Vernal pool. Local, uncommon. [H. geniculatum All.] (BS, J\&S)

*Hordeum murinum L. ssp. leporinum (Link) Arcang. Foxtail barley. Grasslands. Widespread, common. [H. leporinum Link] (BS, J\&S)

Koeleria macrantha (Ledeb.) J. A. Schultes. Prairie junegrass. Grasslands. Local, uncommon. [K. cristata (L.) Pers., $K$. nitida Nutt.] (BS, J\&S)

*Koeleria phleoides (Villars) Pers. Bristly junegrass. Open, thin-soiled areas in grasslands, coastal scrub. Local, uncommon. [K. gerardii (Villars) Shinners] (BS, J\&S)

*Lamarckia aurea (L.) Moench. Goldentop. Coastal scrub. Widespread but uncommon. (BS, J\&S)

Leymus triticoides (Buckley) Pilger. Creeping wildrye. Grasslands, freshwater seep. Common. [Elymus triticoides Buckley] (BS, J\&S)

*Lolium multiflorum Lam. Italian ryegrass. Grasslands, vernal pool. Common. (BS, J\&S)

*Lolium perenne L. Perennial ryegrass. Swale in grasslands. Local, uncommon. (J\&S)

Melica californica Scribner. California melic. Rock outcrops in grasslands, blue oak woodland. Local, uncommon (BS, J\&S)

Nassella cernua (Stebbins \& Love) Barkworth. Nodding needlegrass. Grasslands. Common. [Stipa cernua Stebbins \& Love] (BS, J\&S) 
Nassella pulchra (A. Hitchc.) Barkworth. Purple needlegrass. Grasslands. Common. [Stipa pulchra A. Hitchc.] (BS, J\&S)

* Phalaris paradoxa L. Paradox canary grass. Swale in grasslands; Local, uncommon. (J\&S)

*Poa annua L. Annual bluegrass. Grasslands. Local, uncommon. (BS, J\&S)

*Poa bulbosa L. Bulbous bluegrass. Grasslands. Local, uncommon. (BS, J\&S)

Poa secunda J. S. Presl. One-sided bluegrass. Grasslands. Widespread, common. [P. scabrella (Thurb.) Vasey] (BS, J\&S)

*Polypogon interruptus Kunth. Ditch beard grass. Freshwater seep. Local, uncommon. (BS, J\&S)

*Polypogon monspeliensis (L.) Desf. Annual rabbit's-foot grass. Freshwater seep, vernal pool. Local, uncommon. (BS, J\&S)

*Schismus arabicus Nees. Arabian grass. Rock outcrops in grasslands, ruderal. Widespread but uncommon. (BS, J\&S)

*Schismus barbatus (L.) Thell. Mediterranean grass. Coastal scrub. Widespread but uncommon. (J\&S)

*Taeniatherum caput-medusae (L.) Nevski. Medusa-head. (BS)

*Vulpia bromoides (L.) S. F. Gray. Foxtail fescue. Grasslands. Uncommon. (J\&S)

Vulpia microstachys (Nutt.) Benth. var. ciliata (Beal) Leonard \& Gould. Ciliate fescue. Blue oak woodland, grasslands. Widespread but uncommon. (J\&S)

Vulpia microstachys (Nutt.) Benth. var. confusa (Piper) Leonard \& Gould. Hairy-leaved fescue. Grasslands. Widespread but uncommon. (BS, I\&S)

Vulpia microstachys (Nutt.) Benth. var. pauciflora (Beal) Leonard \& Gould. Few-flowered fescue. Grasslands. Widespread but uncommon. (BS, J\&S)

*Vulpia myuros (L.) C. Gmelin. Rattail fescue. Grasslands. Widespread but uncommon. (BS, J\&S)

Vulpia octoflora (Walter) Rydb. var. hirtella (Piper) Henrard. Eight-weeks fescue. Coastal scrub. Local, uncommon. (BS, J\&S) 


\section{Potamogetonaceae (Potamogeton Family)}

*Potamogeton crispus L. Crispate-leaved pondweed. (BS)

\section{Typhaceae (Cattail Family)}

Typha angustifolia L. Narrow-leaved cattail. Cattail wetland, freshwater seep. Local, uncommon. (BS, J\&S)

Typha domingensis Pers. Southern cattail. (BS)

Typhe latifolia L. Broad-leaved cattail. Cattail wetland, freshwater seep. Local, uncommon. (BS, J\&S)

\section{Excluded Species}

BioSystems' survey included a number of taxa from Site 300 that appear to be erroneously reported. These taxa include:

Alyssum alyssoides (L.). This species does not occur in central western California; possibly a misidentification of erect-fruited Lepidium nitidum $\mathrm{T}$. $\&$ G.

Fritillaria bicolor Lindley. Misidentification of Fritillaria agrestis Greene.

Gilia capitata Sims ssp. abrotanifolia (Greene) V. Grant. This is a southern California subspecies; probably a misidentification of ssp. staminea:

Hordeum pusillum Nutt. This is a synonym of $H$. intercedens Nevski, a southern California species; possibly a misidentification of $H$. depressum.

Lagophylla glandulosa Gray. This is a late summer- to fall-blooming species that does not occur in central western California; probably a misidentification of Lagophylla ramosissima.

Plagiobothrys hystriculus (Piper) Jtn. This species, which is presumed to be extinct, is endemic to Solano County; possibly a misidentification of Plagiobothrys acanthocarpus (Piper) Jtn.

Plagiobothrys tener (Greene) Jtn. This species does not occur in central western California; possibly a misidentification of Plagiobothrys trachycarpus (Gray) Jtn. or a typographic error for $P$. tenellus (Nutt.) Gray.

Plantago eriopoda Torr. This species does not occur in central western California; possibly a misidentification of Plantago lanceolata. 
Poa palustris $\mathrm{L}$. This is a montane species that does not occur in central western California; possibly a misidentification of Poa pratensis $\mathrm{L}$.

Ribes divericatum Dougl. This species is coastal and does not occur in the interior foothills; probably a misidentification of $R$. quercetorum Greene.

Thelypodium lemmonii Greene. This species occurs in the central to southern South Coast Ranges but not as far north as Alameda County. Probably a misidentification of Guillenia flavescens.

Triteleia elegans. This is not a valid name; probably a typographic error for Brodiaea elegans.

\section{References}

Al-Shehbaz, I. A., and R. A. Price. 1998. Delimitation of the genus Nasturtium (Brassicaceae). Novon 8: 124-126.

Baldwin, B. G. 1999. New combinations and new genera in the North American tarweeds. Novon 9: 462-471.

Baldwin, B. G., R. E. Preston, B. L. Wessa, and M. Wetherwax. 2001. A biosystematic and phylogenetic assessment of sympatric taxa in Blepharizonia (Compositae-Madiinae). Systematic Botany 26: 184-194.

Berg, R. Y. 1996. Development of ovule, embryo sac and endosperm in Dipterostemon and Dichelotemma (Alliaceae) relative to taxonomy. American Journal of Botany 83: 790-801.

BioSystems Analysis, Inc. 1986b. A tare plant survey of Site 300, Lawtence Livermore National Laboratory, San Joaquin County, California. November 1986. Santa Cruz, CA. Prepared for Science Applications International Corporation, Pleasanton, CA.

CalFlora: Information on California plants for education, research and conservation. [web application]. 2000. Berkeley, California: The CalFlora Database [a non-profit organization]. Available: http://www.calflora.org/.

Chan, R. 2001. Taxonomic changes and a new species in Lasthenia Sect. Amphiachaena (Compositae: Heliantheae sensu lato). Madroño 48(3): 205-210.

Hickman, J. C. (ed.). 1993. The Jepson manual. University of California Press, Berkeley, CA.

Hoover, R. F, 1936. New California plants. Leaflets of Westem Botany 1:225232. 
Preston, R. E. 1997. Dittrichia graveolens (Asteraceae), new to the California weed flora. Madroño 44: 200-203.

Reveal, James. Professor. University of Maryland, College Park. October 15, 1997 - E-mail.

Webster, G. L. 1992. Realignment in American Croton. Novon 2: 269-273. 
- 


\section{Appendix A-2 \\ California Native Species Survey Forms}




\section{California Native Species Field Survey Form}

Mall to:

Natural Diversity Data Base

- Califomia Dept. of Fish and Game

14.16 Ninth Street, 12th Floor Sacramento, CA 95814

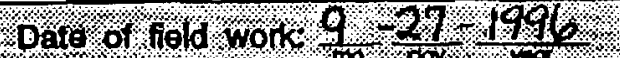

\begin{tabular}{|lc|}
\hline Source Code & For office use only \\
Elm Code & Quad Code \\
Copy to & Occ \# \\
\hline
\end{tabular}

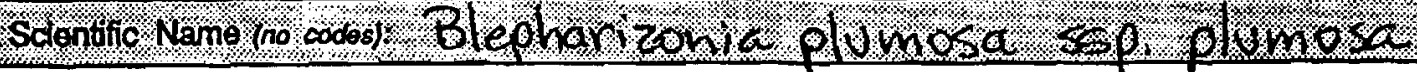

Species Found? $M(1)$

yes no

Total \# Individuals:

If not, why?

Subsequent visit? [ ]yes Mno

Compared to your last visit: [ ]more [ ]same I ffewer

Is thls an existing NDDB occurrence?

Collection? If yes:

$\tau^{2} \overline{\text { number }}$ Musoumherbarium

\section{Plant Information:}

7 Phenology:

\% vegetative $\frac{100}{\% \text { flowering }}$

\% fruiting

Location: (Please also attach or draw map on back.)

$T^{2}$

Lawrence Livermore National Laboratory, Site 300 see attuclued map + descriptions

county: San Joaquin

Quad Name: Midway
Landowner/Mgr: Elevation:
Reporter: Robert E. Preston

Address: 1705 Albion Pl., Davis, CA 95616

Phone: (916) 737-3000 (office) 753-6478(hw)

Other knowledgeable individuals (name/address/phone):

Tina Carlsen (510) $422-7103$

Environmental Restoration Division

Law rence Livemone National Lalsoratory

\section{Animal Information:}

Age Siructure:

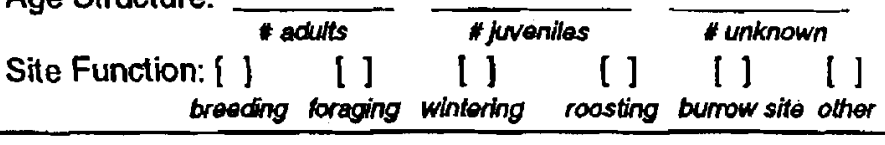

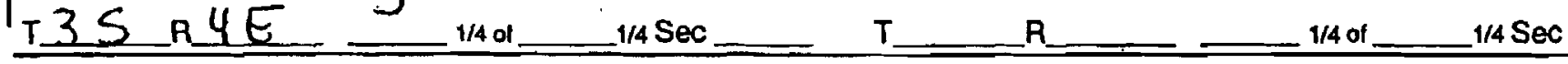

Habitat Doscription: (Planl communities, dominants, associales, substrate/soils, aspectslopo)

observed primarily in controlled Gurn areas - annual grassland on day to day loam soils, usually on slopes - see attached description. Also ocaus on roadsider.

Other rare spp.?

Sitt Information: Current/surrounding land use: Energy + weapons reasearch facilities with 1 much open space/ungrazed annwial grassland. Some areas burned visible disturbances, possible threats: a nnually for five suppression. minor habitat loss 7 possible from proposed projects. often found in disturbed sites! loverall site quality: [ ]Excellent WGood I ]Fair I ]Poor comments:

Doteminiation: (Check one or more, fill in the blanks)

Koyed in a sile reference:

Compared with specimen housed at:

Compared with photo/ctawing in:

By another person (name):

other: personal familicrit

Photographs: (Check one or more)
PlanVanimal
Habltat
Olagnostic Feature
Other
May wo obtein duplicales at our expense? I lyes $\overline{I \text { Jno }}$


Blepharizonia plumosa ssp. plumosa observations at LLNL Site 300:

1) Building 834 complex, on slopes adjacent to buildings and at roadsides; T. 3 S., R. $4 \underset{\mathrm{W}}{E}$, nw $1 / 4$ of ne $1 / 4$ Section 26 , elev. 1,040 ft. Nonnative annual grassland (unburned), with $A$ vena sp., Gutierrezia californica, Eriogomum angulosum, Bromus diandrus, Holocarpha obconica. Soil mapped as Alo-Vaquero complex, 8 to 30 percent slopes (clay soil). A few hundred plants. May be affected by vegetation management for fire control. Voucher: R. E. Preston 1006, 04 Oct 1996 (DAV).

2) On north-facing slope of Elk Ravine, ca. 1,000 ft wnw of Building 834 complex; T. 3 S., R. 4

$E$. $n$ 1/2 of nw $1 / 4$ Section 26 , elev. 740-900 ft. Nonnative annual grassland (annually burned), with Bromus hordeaceus, Bromus diandrus, Amsinckia intermedia, Bromus madritensis ssp. rubens, Leymus triticoides, Grindelia camporum. Clay or clay loam soil, mapped as WisflatArburua-San Timoteo complex, 50 to 75 percent slopes. Between 500 and 1,500 plants.

Proposed drainage culvert may cross east end of the population.

3) On slopes of small canyon, south of Building 812 complex; T. 3 S., R. 4 ., sw $1 / 4$ of nw $1 / 4$ and ne $1 / 4$ of sw $1 / 4$ Section 22, elev. 1,000 ft. Soil mapped as Wisflat-Arburua-San Timoteo complex, 30 to 50 percent slopes. Several hundred plants.

4) On west-facing slopes adjacent to Building $801 ;$ T. 3 S., R. 4 ., se $1 / 4$ of se $1 / 4$ Section 16 and sw $1 / 4$ of sw $1 / 4$ Section 15 , elev. 1,150 ft. Non-native annual grassland (annually burned). Clay soil, mapped as Wisflat-Arburua-San Timoteo complex, 30 to 50 percent slopes, south of Bldg 801 , and Alo-Vaquero complex, 8 to 30 percent slopes, north of Bldg 801. Several hundred plants. Building construction may affect less than a dozen plants. Voucher: R.E. Preston 1002, 27 Sep 1996 (DAV).

5) On north-facing slope, in and along dirt road and lower slope, ca. $100 \mathrm{ft}$ southeast of Building 850; T. 3 S., R. 4 ., se $1 / 4$ of se $1 / 4$ Section 17, elev. 1,300 feet. Disturbed annual grassland (annually burned). Rocky clay loam soil, mapped as Wisflat-Arburua-San Timoteo complex, 30 to 50 percent slopes. Approximately 100 plants. May be affected by future construction of drainage ditch around site.

6) Plants also occur along roadsides and in disturbed areas around the LLNL site; T. 3 S., R 4 ., Sections 15, 16, 21, 22, 26, and 27 (dots marked on attached map). Blepharizonia plumosa ssp. viscida also collected on site in Section 21.

Additional populations are highly likely to occur on the Site 300 , in particular, the north $1 / 2$ of Section 21. 
(1)

to

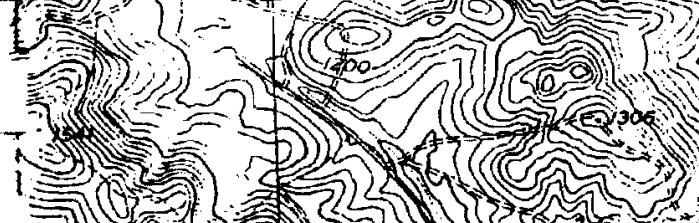

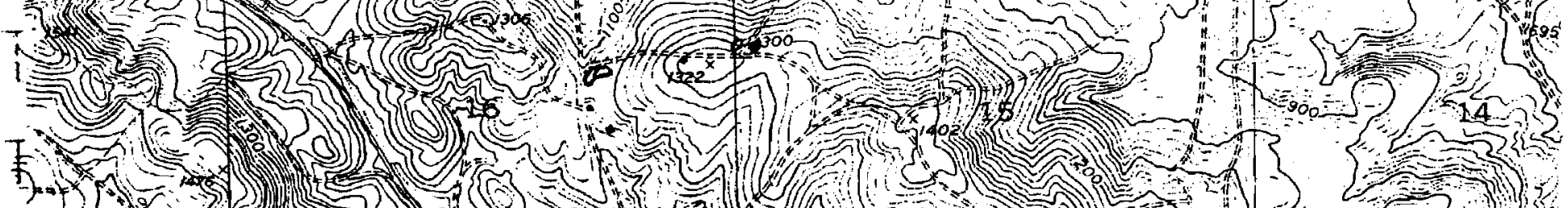

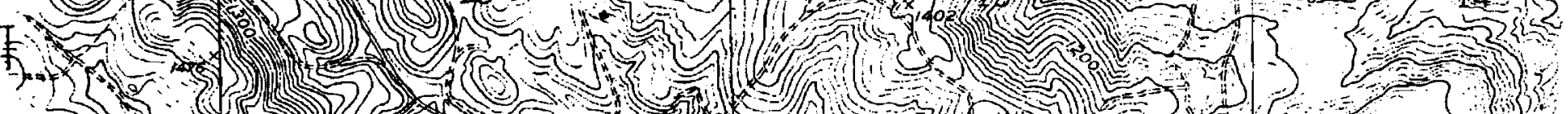

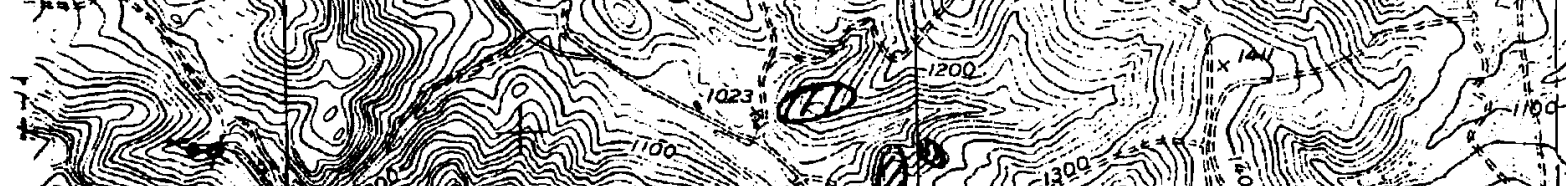
It (5) 1. D.

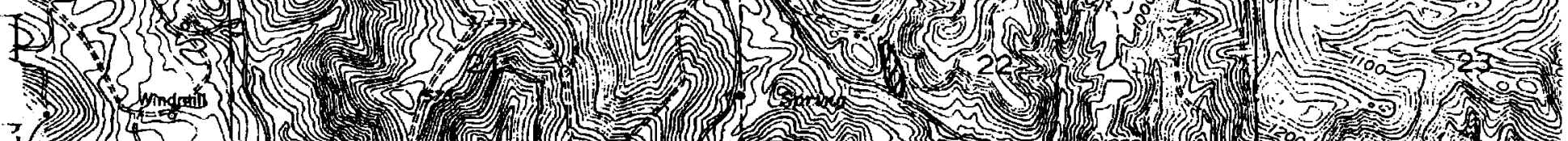

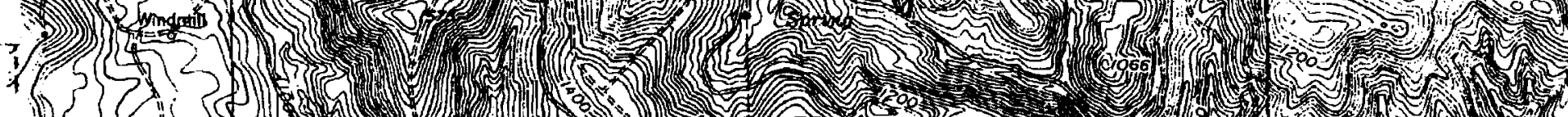

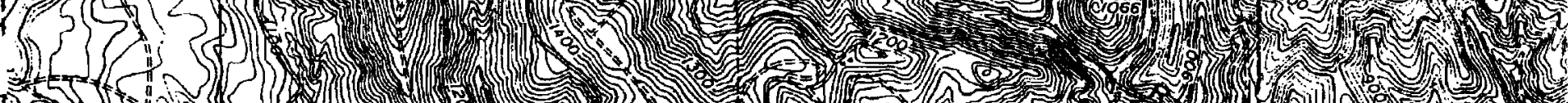
N. H

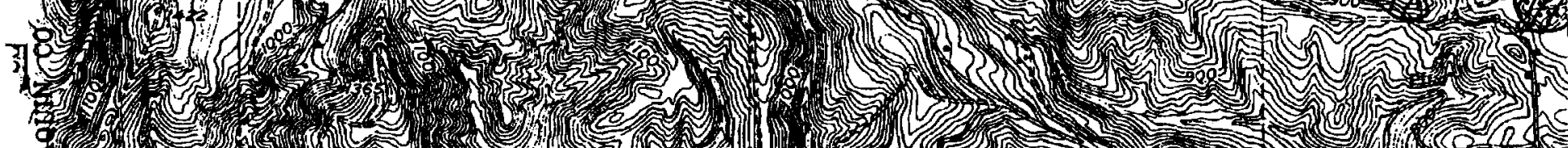

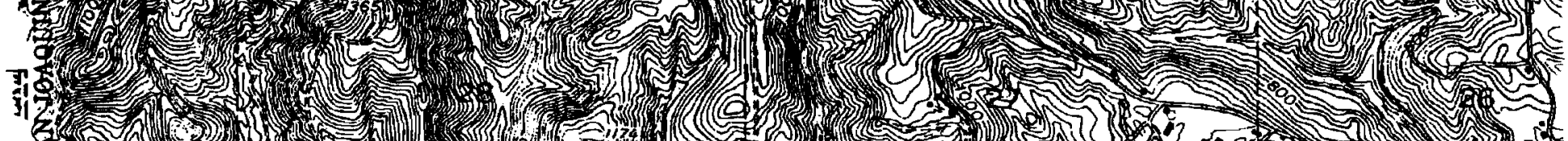
J) SL

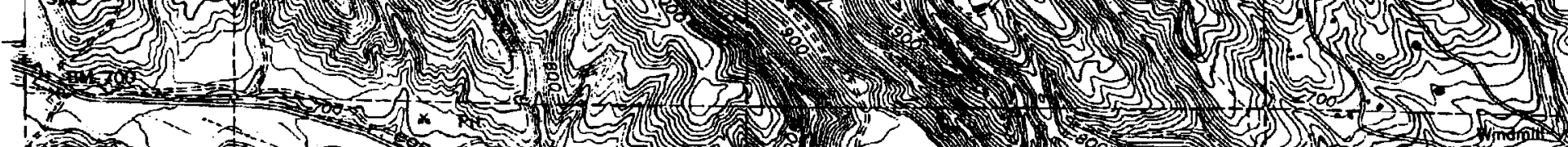
J (19) 


\section{California Native Species Field Survey Form}

Mall to:

Natural Diversity Data Base

California Dept. of Fish and Game

1416 Ninth Street, 12th Floor

Sacramento, CA 95814

Date of field work: $\frac{05}{\mathrm{mo}}-\frac{06-97}{\mathrm{doy}}$
For office use only

Source Code Quad Code

Elm Code

Occ \#

Copy to

Map Index *

Sclentific Name (no codes): Esch scholza r hombl petara.

Species Found? M [ ]

yes no

Hnot, why?

Total \# Individuals: 10 Subsequent visit? [ Iyes Mno

Compared to your last visit: [ ]more [ ]same [ ]fewer Is this an existing NDDB occurrence? [ Collection? If yes: $\frac{1028}{\text { number }} \frac{\mathrm{DAV}}{\text { Museum/ierbarium }}$

\section{Plant Information:}

Phenology: $\frac{10}{\% \text { vegetative }} \frac{90}{\% \text { mowering }} \frac{9 \text { ruiting }}{2}$

Location: (Please also attach or draw map on back.)

Lawrence Livermore Nattonal Lab,

Site 300

County: Alameda Landowner/Mgr: US DOE

Quad Name: Midway Elevation:850' UTM:

$T 35 \quad R 4 E$ NW 1/4 of SW $1 / 4$ Sec 29

$R$ $1 / 4$ of $1 / 4 \mathrm{Sec}$

Habitat Description: (Plant communibies, dominants, assoclales, substrato/solls, aspoctslopp)

N-facing slope, on friable clay soil; at ecotone betuveen annval grassland and eroding bank face; with Poa scabrella, Bromus rubens, Avena barbata, Stylomecon heterophylla, Microseris douglasii

Other rare spp.?

Sito Information: Current/surrounding land use:

research facility

visible disturbances, possible threats: erosion

Overall site quality: [ ]Excellen! MGood [ ]Fair [ ]Poor Comments:

Dotermination: (Check one or more, 积 in the blanks)

Koyed in a slte reference:

$\checkmark$ Compared with specimen housed at: UC Berkeley

Compared with photoldrawing in:

By another person (name):

Other:
Photographa: (Check one or more)

Side Pint

Plantanimal

Hebitat

Diegnostic Feature

Other

May we obtain duplicates at our expense? I lyes [ ho 
-

What

N N

W(1)

H.

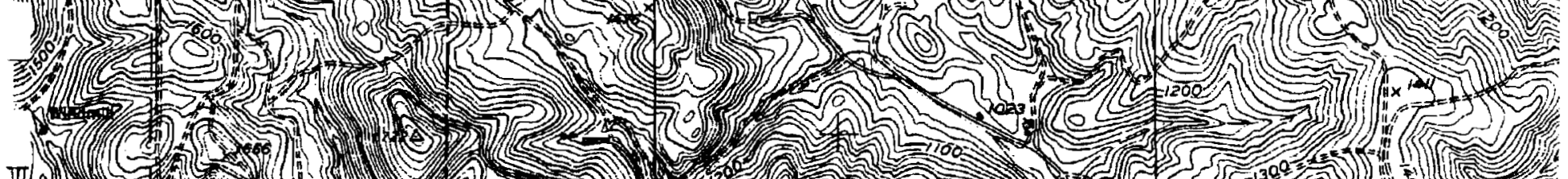

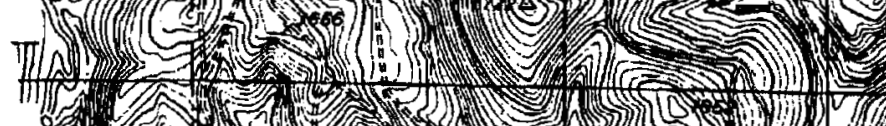

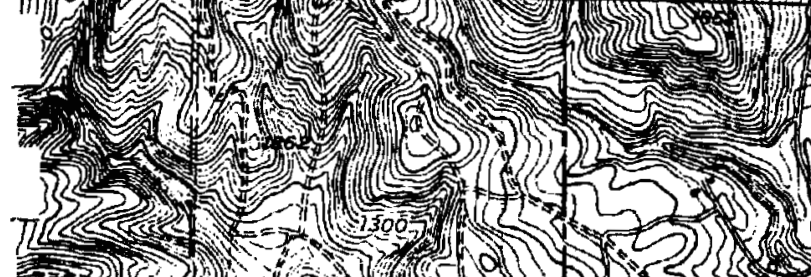
=

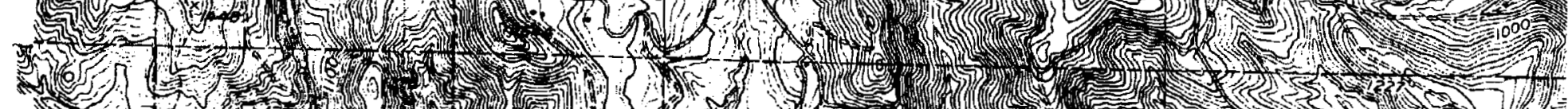

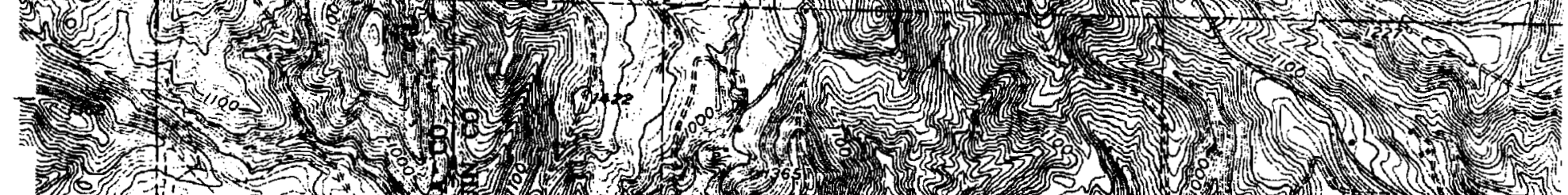
(

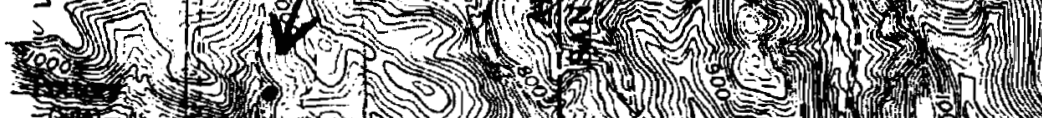
-150) (1) 


\section{California Native Species Field Survey Form,}

Mail to:

Nofurel Diversity Data Bose

Califarnia Department of Fish and Game

1416 Ninth Street, 12th Foor

Sacramento, California 95814

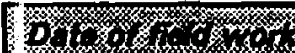

\section{,}

5

\section{For office use oniy}

Source Code

Elm Code

Copy to
Quad Code

Oce *

Map Index \#

\section{\% $0010.1 \%$}

Spocies Found? $\times$

yes no
If not, why?

Total * Individuals 800 subsequent visit? $\square$ yes $\square$ no Is this an existing NDDB occurrence? Collection? if yes: $n 0$ number Yos, O00. Museum/Harberium Plent information

Phenology:

$\overline{* \text { vegatative }} \frac{50}{\% \text { flowering }} \frac{50}{\% \text { frulting }}$

Reportar: Rob Preston, Ron Unger

Address: Jones + Stokes Associates $2600 \mathrm{~V}$ st., Ste 100; Sacramento 9581 Phome: Albi $737-3000$

Age Structure:

\section{Animal information}

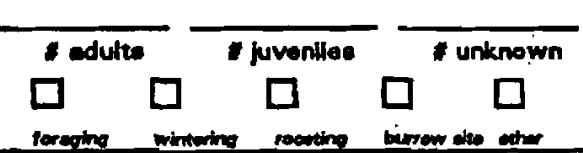

Location (Plowe deo mech or draw mep on back.) Lawrence Livermore National Laboratory, Site 300 San 7 populatumi-see atduched map.

County: San Joqguln Landownermgr: USOOE

Quad Name: Midwdy Elevation:600-1400 UTM:
T 35 R $4 E$ $-y_{k}$ of $x \sec 152126 T$
R $\quad y_{4}$ of $1 / 4$ Sec

Habitat Description (Plant oommunites, dominants, eseoclates, eubetroto/solla, aspecta/slope)

6 populationin on upper slopes (ridges, saddles) in perennial grassland, of Nasella cernua, Poa scabrella, Erodium cicutarium, marah fabaceus 1 population on E-facing road cut, in annual grassland, Bromus SpP other rera app.r Alepharizonia plumosa ssp. plumosa dominant

Sito Information Overall site quality: $\otimes$ Excellent $\square$ Good $\square$ Fair

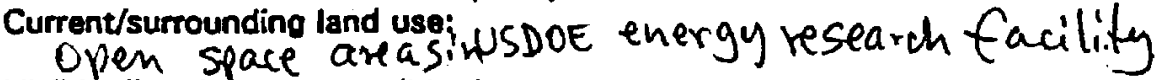

Visible disturbances, possible threats:

Comments:

Native grassland bumed annually which appears to favor native species; timing of burns may affect seed set in later-flowering species.

Doterminotion: (Check one or more, fill in the blanke

CKeyed in a site roforence: Lenson Manval

Compared with epecimen housed at:

Compared with photo/drawing in:

By another porson (neme): Other:
Phosegraphs: (Check one or more) stide Pint Plont/animal Mabitat

Diagnoatic Feeture

May we obtain duphicates at our expense? $\square$ Yes $\square$ No 
(1)

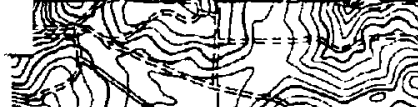

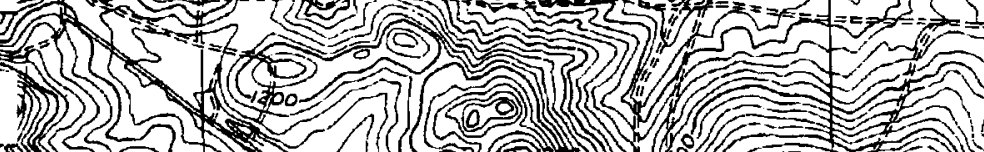

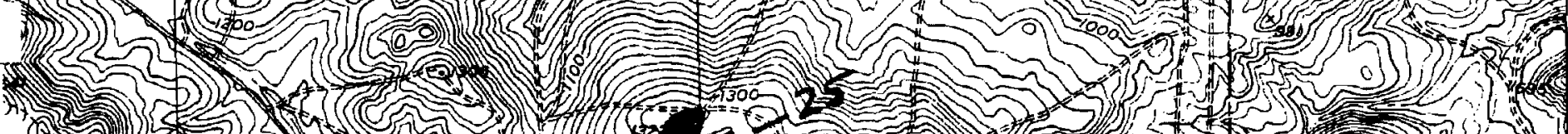
-

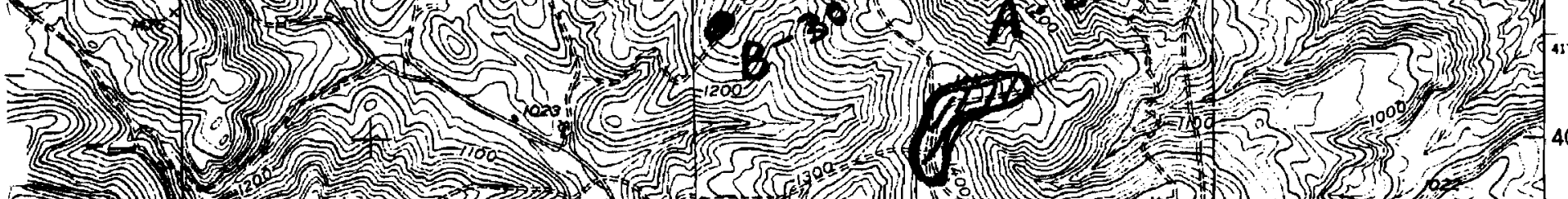

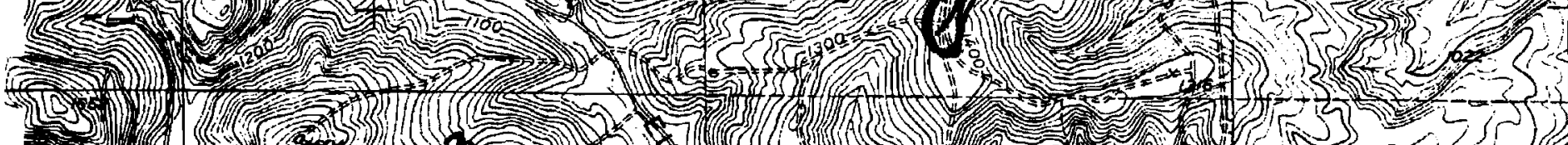
- S.5. (n)

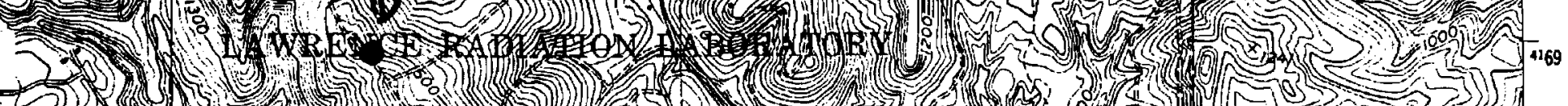

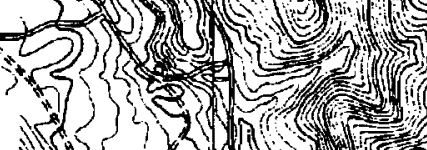

syinghin

$(2)$

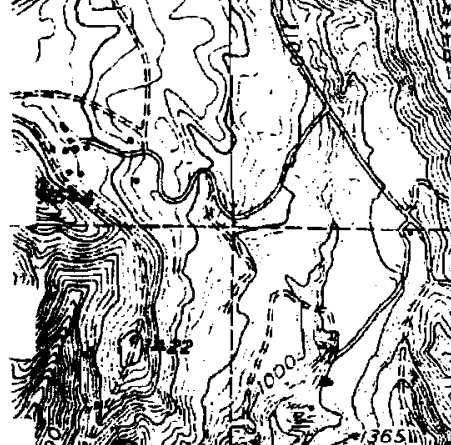

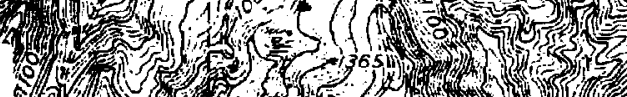

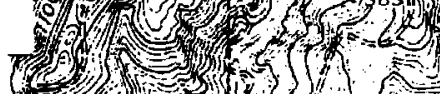

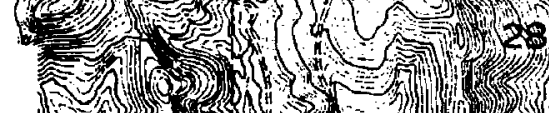

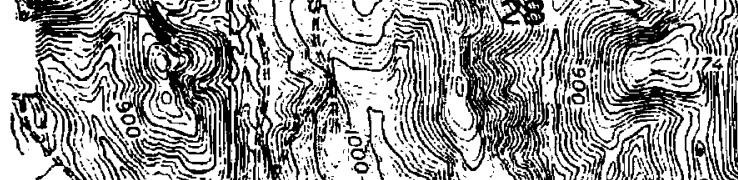

-2)
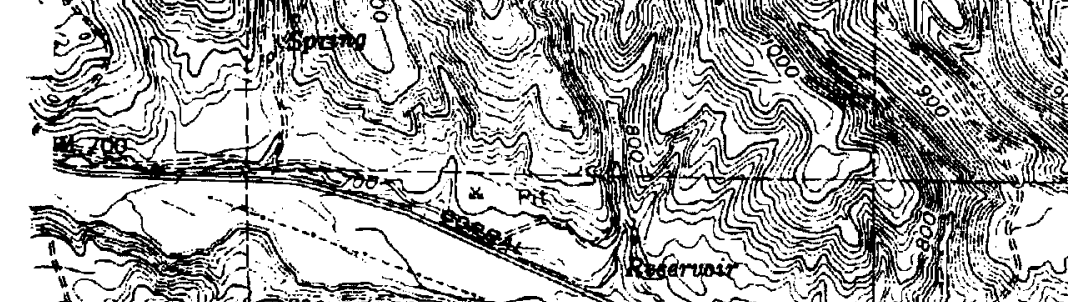

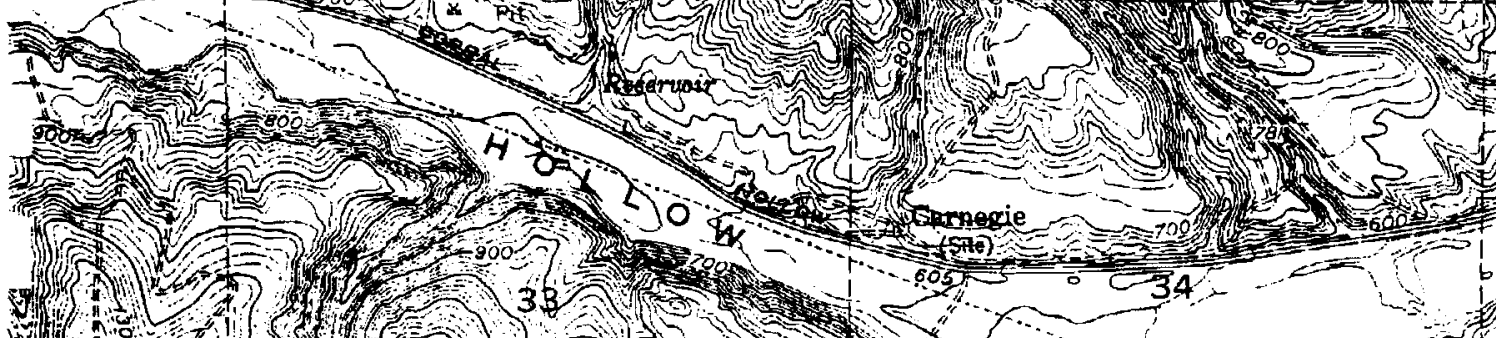

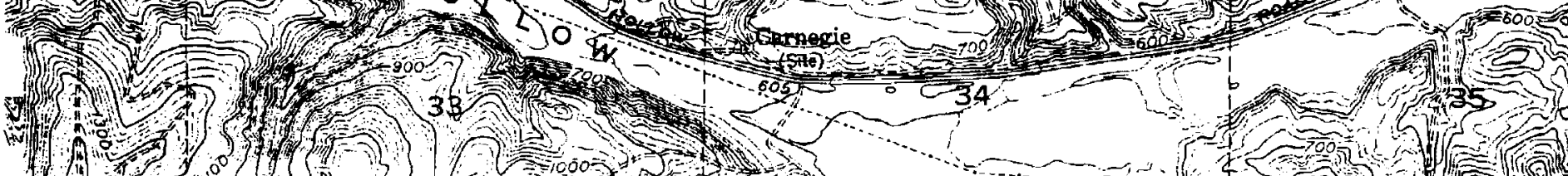




\section{California Native Species Field Survey Form}

Mail to:

Naturat Diversity Database

California Department of Fish and Game

$180713^{\text {th }}$ Street, Sute 202

Sacramento, CA 95814

P

For Office Use Onily

Source Code

Quad Code

Elm Code

Occ. No.

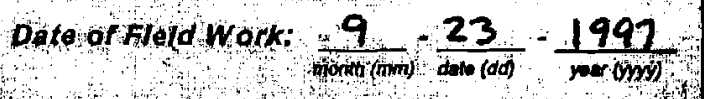

EO Index No. Map Index No.

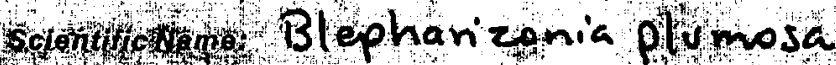

thy

oomnoninge.

Specles Found?

yes no

Total No. Individuals Subsequent Visit? BYres $\square$ no

Is thls an existing NDDB occurrence?

Yes, Occ.

Collection? If yes:

Number Museum / Herbartum

\section{Plant Information}

Phenology:

$$
\text { \% vegetative } \frac{\leftarrow \text { fowering }}{\% \text { foruiting }}
$$

Reporter: Jones + Stolees

Address: $2600 \mathrm{~V}$ street Sacramento, ca 95818

Email Address: rpreston ejsanet.com Phone: (91b) $503-6681$

Animal Information

Age Structure:

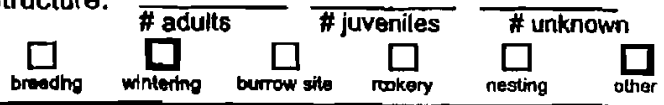

Location (please also attach or draw map on back) L awrence Livemne Natumal Lalnatry. Site 300

County: /San Jaquin Quad Name; midway, Tracy quads
$T 35$ R 35 1/4 of $1 / 4$ of Section $(10,11)$ $1 / 4$ of Section Landowner /Mgr: U.S. DOE

UTM: Zone: (GP S, map \& type, etc.) Point Accuracy:

Datum: $T+R$ $1 / 4$ of Elevation: $800-1600$ $1 / 4$ of Section

Source: (NAD83,NAD 27,WG584, other)

UTM Coordinates

Habltat Description (plant communitios, dominants, associates, substrates/soils, aspocts/slope) Nathl them-mathe granslands, in clay ur clay-Loan srits; H Avena, Bromun, Poa, Nancella, Molocarphe obcomia, Grindelia campoum. Mirschfeldia incana, Other rare species? Eniogomin angularum.

Site information Overall site quality: $\square$ Excellent $\square$ Good $\square$ Fair $\square$ Poor

Current / sumounding land use:

Visible disturbances / possible threats:

comments: 26 standr scatoued across the wite, min feetume $15,16,17,20,21,22$, and 26 , See attaked census.

Determinatlon: (check ons or more, and fil in blenks)

$\square$ Keyed (cite eference)

$\square$ Compared with secimen housed at:

$\square$ Compared with photo / drawing in:

$\square$ Byanother person (namel:

Other:
Photographs: (ctreck one or more) Slide Print Plant/ animal

Habitat

Dlagnostic feature

May we obtain duplicates at our expense? $\square$ yes $\square$ no 


\section{California Native Species Field Survey Form}

Mail to:

Natural Diversty Database

California Department of Fish and Game

$180713^{\text {th }}$ Street, Sute 202

Sacramento, CA 95814

Dateof fleldwork $\frac{3}{2 B}-\frac{2002}{20 \text { tod }}$
C

Source Code

Elm Code

EO Index No.
For Office Use Only

Quad Code

Occ. No.

Map Index No.

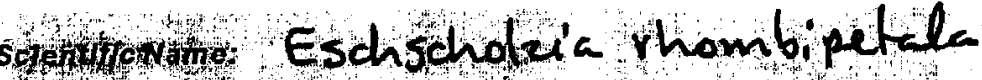
comothothe

Specles Found?

Total No. Individuals 300 Subsequent Visit? Dyes Qhio

Is this an existing NDDB occurrence? ___ Etio $\square$ unk.

Yes, Occ. \#

Collection? If yes:

$$
\text { Number Museum / Herbarium }
$$

\section{Plant Information}

Phenalogy:

$$
\text { \% vegetative } \frac{100 \% 0}{\% \text { flowering }} \frac{}{\% \text { fruiting }}
$$

Location (please also attach or draw map on back) (aureme Lueimone Natamal Lalonatay, Site 300

county: Alameda Landowner /Mgr.: US DOE

Quad Namo: Miduvary

T 35 RE SE $1 / 4$ of $\underline{\text { nW }} 1 / 4$ of Section 20

UTM: Zone: 10 $(10,11)$

(GPS, map \& type, etc.) Point Accuracy: Datum: NAD 27 $R$ $1 / 4$ of Elevation: 1, 391'

Source: GPS

UTM Coordinates $627035 \mathrm{~S}, 4168738 \mathrm{~N}$

Reporter: Jones + Stokes

Address: $2600 \mathrm{~V}$ street Sacramento, ca 95818

Emall Address: rereston $C$ is a net.com Phone: $(9 / 6)$. $503-6681$

Anlmal Information

\begin{tabular}{|c|c|c|c|c|}
\hline & \# adulls & & uveniles & \# unknown \\
\hline 3 & $\square_{\text {mintering }}^{\square}$ & $\square$ & $\square_{\text {rookery }}$ & $\square_{\text {nesting }} \quad \square_{\text {other }}$ \\
\hline
\end{tabular}

Age Structure:

Habltat Description (plant communitios, dominants, associates, substrates/soils, aspoctsistope) Amunchand on w-facing alore; with Avena, Bromes, Poa Alenda

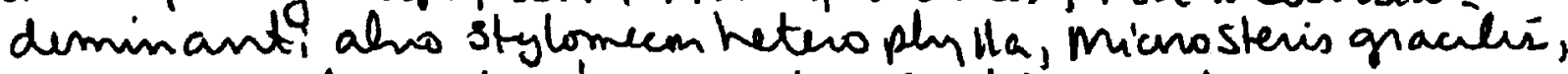
Other rare species? Amsinchía ly copsoides, Grodin ciantanuin

site information Overall site quality: पExcollent $\square$ Good $\square$ fair $\square$ poor

Current / surrounding land use:

Visible disturbances / possible threats: Mnome

comments: Discorered by Manganet Widdowsm

Dotermination: (check one or more, and it in blanks)

D Keyed (cite meference)

$\square$ Compared with epecimen hased at:

$\square$ Compared with ptoto / drawing in:

G Byanother person (name): Colent PNes Rum

$D$ Other:
Photographs: (check one or more) Slide Print Plant/animal

Habitat

Diagnostic feature

May we obtain dupllates at our expene? $\square$ yes $\square$ no 


\section{Eschscholutic rhombipetala}

TOPO! map printed on 07/22/02 from "California.tpo" and "Untitied.tpg"

$626000 \mathrm{mE}$. $\quad 627000 \mathrm{mE}$.

NAD27 Zone $10 S 629000 \mathrm{mE}$.
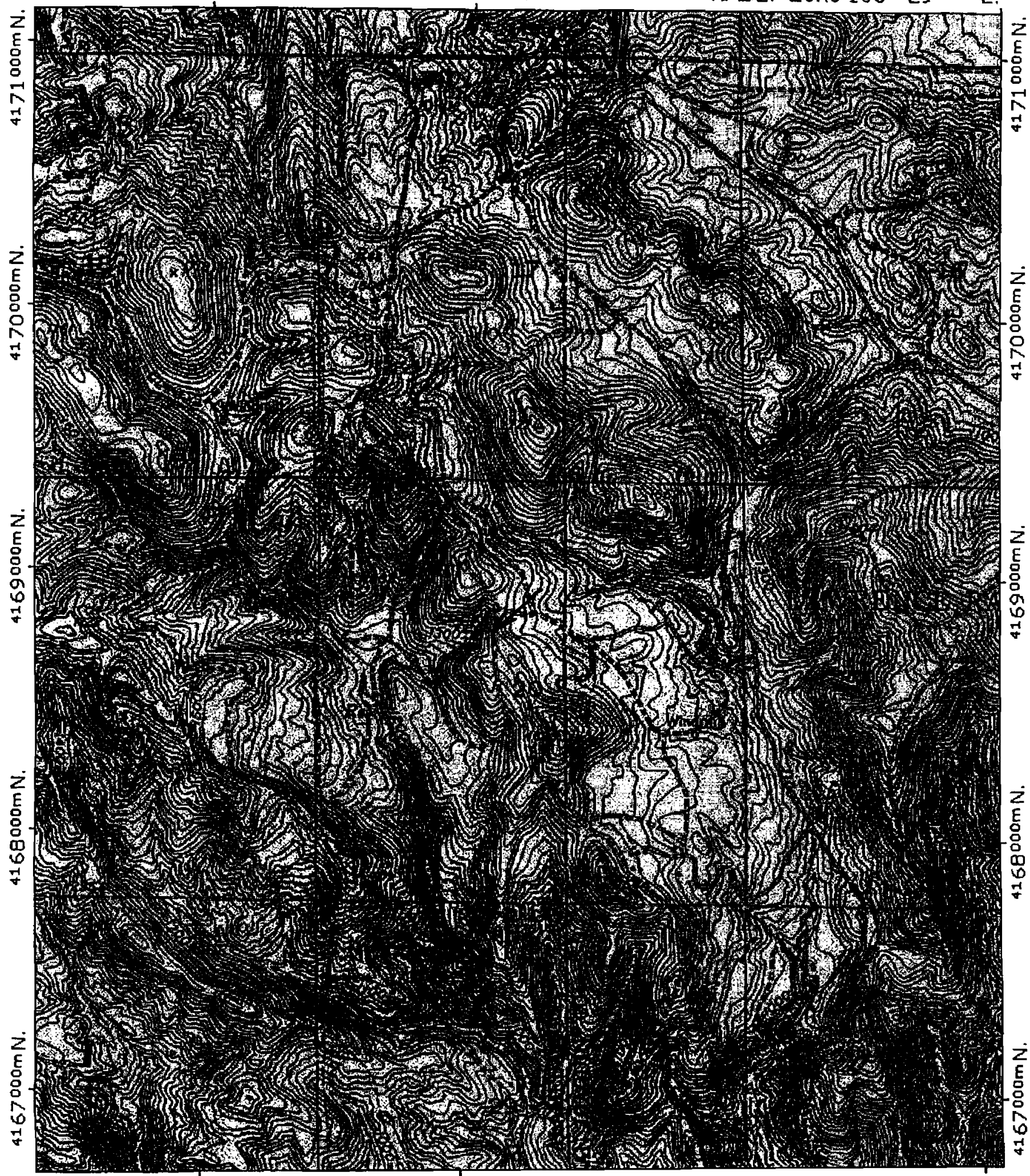

$626000 \mathrm{mE}$.

$\operatorname{TN}\left(\begin{array}{c}M N \\ 15^{\circ}\end{array}\right.$

$627000 \mathrm{mE}$.

NAD27 Zone 1 OS $629000 \mathrm{mE}$

4 MIL

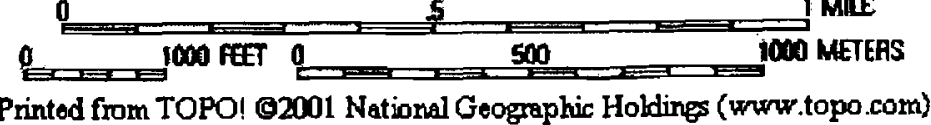

Midway 


\section{California Native Species Field Survey Form}

Mail to:

Natural Diversity Database

California Department of Fish and Game $180713^{\text {th }}$ Street, Suite 202

C

Sacramento, CA 95814

Source Code

Elm Code

Date of Eield Work $\frac{3}{2}, 29,1002$

EO index No. No. $\mathbb{W}$

For Office Use Only Quad Code Occ. No. Map Index No.

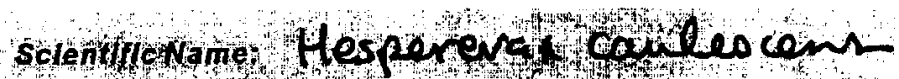
dowmonnames

Species Found? $\underset{\text { yes }}{\square} \underset{\text { no }}{\square}$ Total No. Individuals

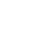

Is this an existing NDDB occurrence? Yes, Occ. \#

Collection? If yes:

Number Museum / Herbarium

\section{Plant Information}

Phenology:

$$
\frac{100 \% \text { vegetative }}{\% \text { flowering }} \frac{}{\% \text { frulting }}
$$

$\square$ yes Eno

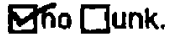

\section{Location (please also attach or draw map on back) Lalonatry. Site 300}

county: Alameda Landowner/Mgr.: US DOE
Quad Name: Midusan
T $3 S$ R 4 SE $1 / 4$ of nw $1 / 4$ of Section $20 \quad T \quad R$ UTM: Zone: $\quad 10 \quad(10,11) \quad$ Datum: NADZ7 Source: $\mathrm{APS}$ (GPS, map \& type, etc.) Point Accuracy: _._ 4
UTM Coordinates Email Address: rpreston Cjsanet.com Phone: (916) $503-6681$

\section{Animal Information}

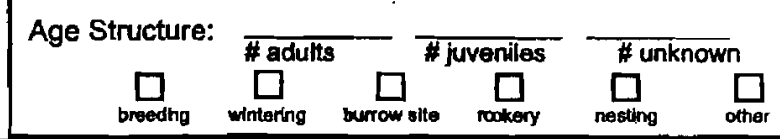

Habitat Description (plent communities, dominants, assoclates, substrates/soils, aspocis/siope) Natane on areland; open anea ust th deme day sil

Other rare species?

Site information Overall site quality: Eexcellent $\square$ Good $\square$ Fair $\square$ poor

Current / surrounding land use:

Visible disturbances / posslble threats: mo

Comments:

Determination: (check one or more. and fil in blanks)
$\square$ Comped (cite werence) Defpum with pecimen housed at:
$\square$ Compared with photo / drawing in:
$\square$ Byanother person (name):
$\square$ Other:

$\begin{array}{lcc}\text { Photographs: (check one or more) } & \text { Slide } & \text { Print } \\ \text { Plant/ animal } & \square & \square \\ \text { Habitat } & \square & \square \\ \text { Diagnostic feature } & \square & \square\end{array}$

May we obtain dupllcates at our expense? $\square$ yes $\square$ no 


\section{Hesperevar caules ene}

TOPO! map printed on 07/22/02 from "California.tpo" and "Untltled.tpg"

$626000 \mathrm{mE}$

$627000 \mathrm{mE}$

$628000 \mathrm{mE}$.

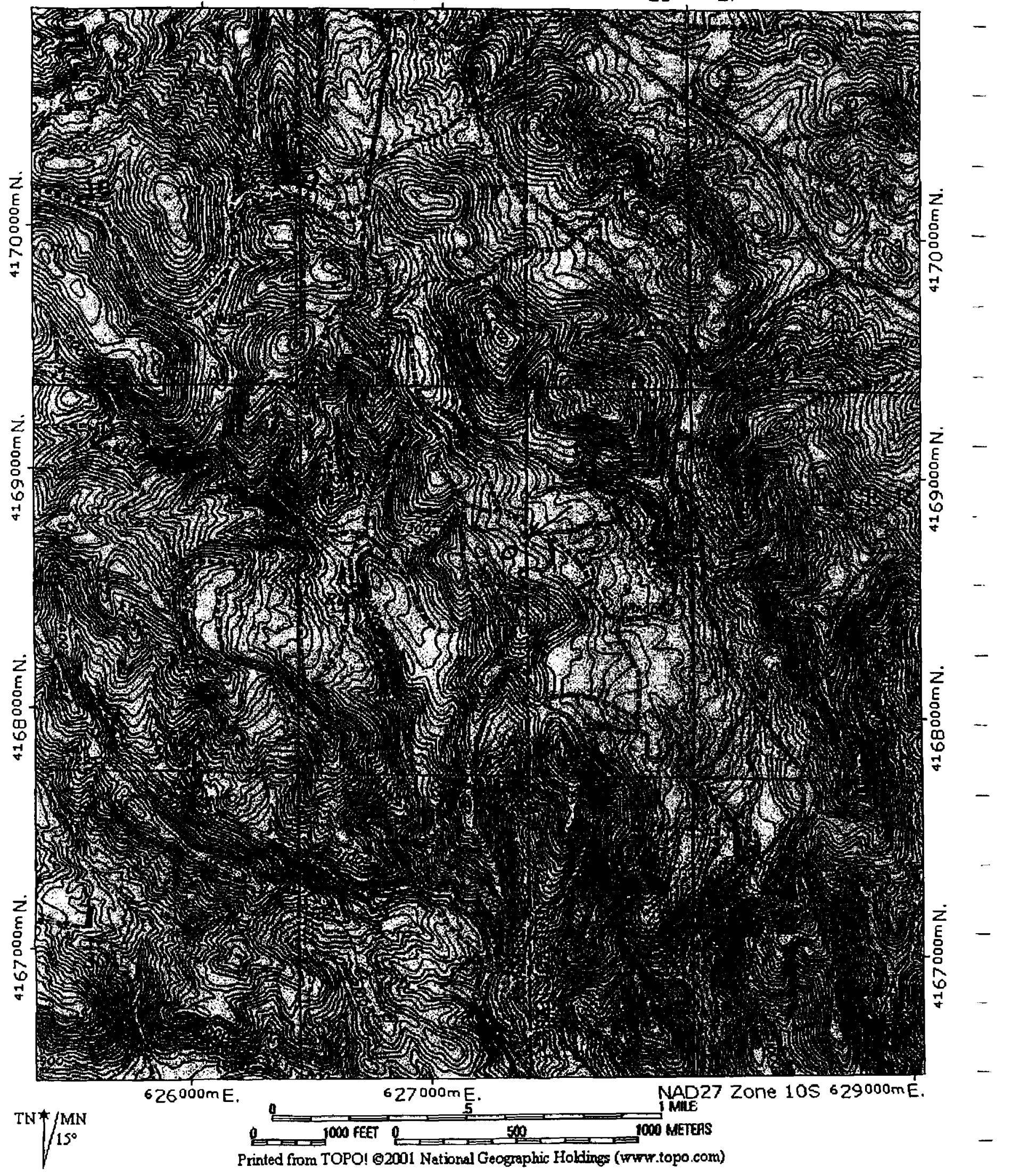

$$
\text { Miduay } 7.5^{-1} \text { quad }
$$




\section{California Native Species Field Survey Form}

Mail to:

Natural Diversity Database

California Department of Fish and Game $180713^{\text {th }}$ Street, Suite 202

Sacramento, CA 95814

$\mathbb{C}$

Source Code

Elm Code

EO Index No.

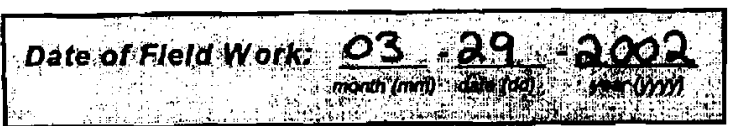

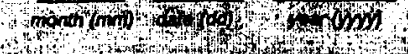

For Office Use Only

Quad Code

Occ. No.

Map Index No.

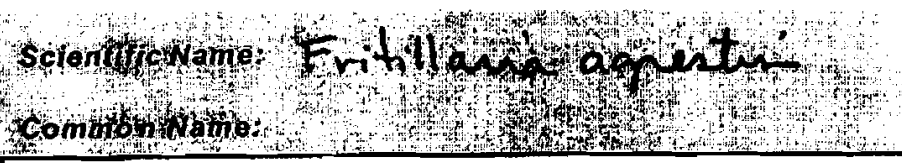

Species Found? yes no

Total No. Individuals 100 's Subsequent Visit? $\square$ yes [Who Is this an existing NDDB occurrence?

$$
\text { Yes, Occ. \# }
$$

Bho Dunk.

Collection? If yes:

Number Museum / Herbarlum

\section{Plant Information}

Phenology:

$$
\frac{100 \%}{\% \text { vegetative }} \frac{10 \text { flowering }}{\%}
$$

\% fruiting

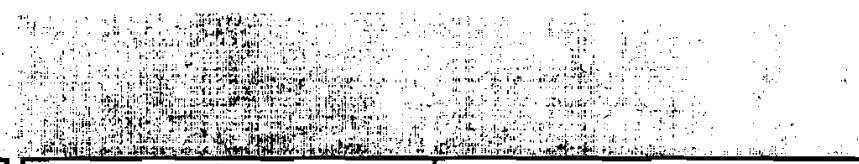

Reporter: Jones + Stolees

Address: $2600 \mathrm{~V}$ Street Sacramento, CA 95818

Emall Address: rpreston ejsanet. com Phone: (916) $503-6681$

\section{Animal Information}

Age Structure:

brooding

Location (please also attach or draw map on back) Launence Li veumne $N$ at tumal Lalmatry, Site 300

County: Alameda Landowner /Mgr.: US DOE
Quad Name: Midulay
TS R $4 E$
UTM: Zone:
$1 / 4$ of
SW $1 / 4$ of Section 17 $(10,11)$
(GPS, map \& type, etc.)
Source:
UTM Coordinates

Habltat Description (plant communtles, dominants, associates, substrates/sods, aspocts/stope) Nathe granaland,

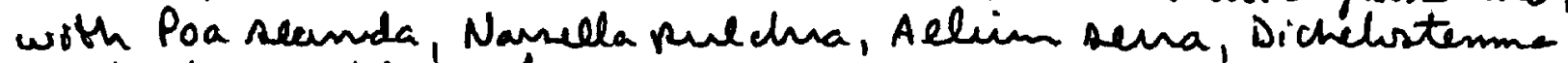
capitaborn, Chlorogalum prmerideanum, Vida pedunculater, Sankeila Other rare species? hipimate.

Site hformation Overall site quality: QExcellent $\square$ good $\square$ fair $\square$ poor

Current / sumounding land use:

Visible disturbances / possible threats: Mrne

Comments: 5 stands: 3 stande with $<12$ plants, a samale stend of 280 plants, and a langen stand wy several hundred plants

Doterminatlon: (chock ons or more. and III in blanks)

D Keyed (cite eferenco)

$\square$ Compared with pectmen housed at:

$\square$ Compared with photo / drawing in:

E. Byanother person (namel: Robert Preston

O Othe:
Photographs: (check one or more) Slide Print Plant/animal

Habilat

Diagnostic feature

May we obtain duplicates at our expense? $\square$ yes $\square$ no 


\section{Fritillaria agreater}

TOPO! map printed on 07/23/02 from "California.tpo" and "Site 300 Plant Waypoints.tpg" $627000 \mathrm{mE}$.

$628000 m E$.

NAD27 Zone $10 S 629000 \mathrm{mE}$.

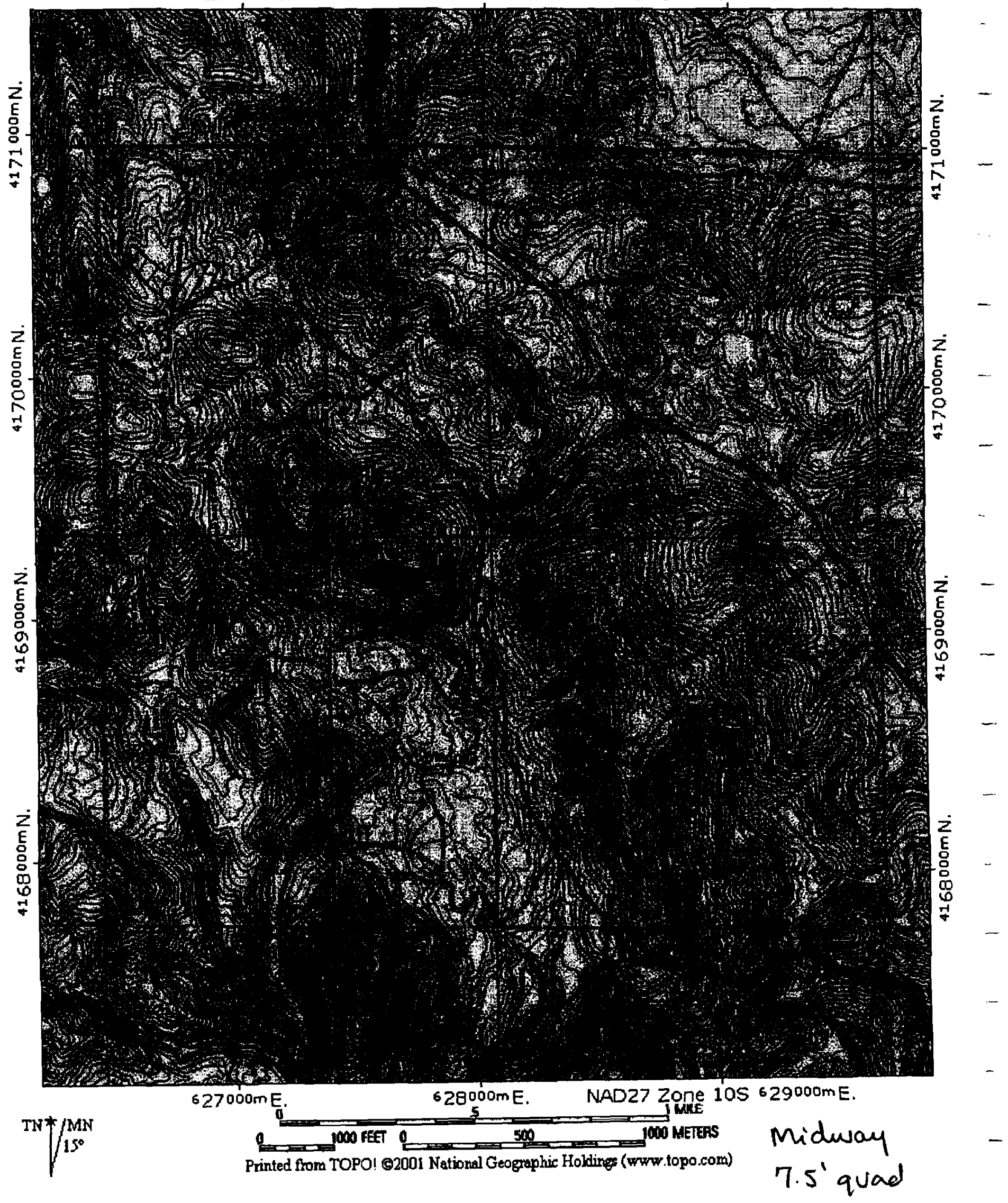




\section{California Native Species Field Survey Form}

Mail to:

Natural Diversily Database

California Department of Fish and Game

$180713^{\text {th }}$ Street, Sulte 202

Sacramento, CA 95814


Source Code Elm Code

EO Index No.

Date of Fleld Work: $3 / 29-4 / 3 / 2002$

For Office Use Only

Quad Code

Occ. No.

Map Index No.

scientrowame Androsace elong ata ssp. acuta

Commonkang

Species Found? $\underset{\text { yes no }}{\square}$

Total No. Individuals

If not, why?

Subsequent Visit?

$\square$ yes $\nabla$ no

Is this an existing NDDB occurrence? __ Wno $\square$ unk. Yes, Occ. \#

Collection? If yes:

$$
\text { Number }
$$

Museum / Herbarium

\section{Plant Information}

Phenology:

$$
\text { \% vegetative } \frac{100 \% \text { flowering }}{\% \text { truiting }}
$$

\section{$\sqrt{1}$}

Reporter: Jones + Stokes

Address: $2600 \mathrm{~V}$ Street Sacramento, $A$ 95818

Email Address: rereston ejsanet. com Phone: (916) $503-6681$

\section{Animal information}

Age Structure:

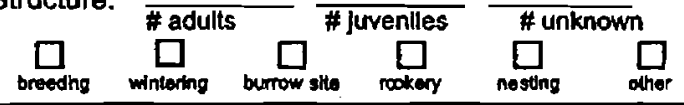

Location (please also attach or draw map on back) Launence Livermene Natumal Lolnatony, Site 300 County: Sam Loaguin Alameda Quad Name: Midway

T 35 R YE $1 / 4$ of UTM: Zone: (GPS, map \& type, etc.) Point Accuracy:

Datum:

$R$
$\mathbf{R}$ $1 / 4$ of Section $(10,11)$

Source:

UTM Coordinates see att ached talle

UTM Coordinates see att ached talle
Elevation: $1 / 4$ of Section (NA D83,NAD 27,WG584, other) Meters

Habitat Description (plant communities, dominants, associates, substrates/soils, aspects/siope) Mun or hichem - Correned bante and roch onterops, m n-facing slopes; with poa seande,

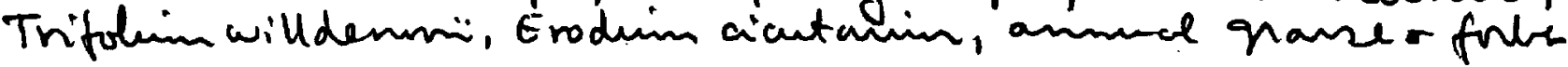

Other rare species?

Site information Overall site quality: WExcellent $\square$ Good $\square$ Fair $\square$ Poor

Current / surrounding land use:

Visible disturbances/possible threats: Mune

Comments: Scattered across Site 300 in Sectumis $15,16,17,21,26,27,+28$

Determination: (check one or more, and $I I$ in blenks)

D Keyed (cite elerence)

D Compared with specimen housed at:

$\square$ Compared with photo / drawing in:

D By another person (name): Powert PNoth

Other:
Photographs: (check one or more) Slide Print

Plant/animal

Habitat

Diagnostic fealure

May we obtain duplicates at our expense? $\square$ yes $\square$ no 
TOPO! GPS Data Format UTM NAD27 ElevFeet UTC-Time

\begin{tabular}{|c|c|c|c|c|}
\hline Waypoint Number & UTM & asting & Northing & ElevFeet \\
\hline ANEL01 & $10 \mathrm{~s}$ & 626644 & 4170286 & 1481 \\
\hline ANEL02 & $10 \mathrm{~s}$ & 627229 & 4170572 & 1336 \\
\hline ANEL03 & 105 & 629156 & 4167732 & 1138 \\
\hline ANEL04 & $10 S$ & 629246 & 4167543 & 1141 \\
\hline ANEL05 & $10 \mathrm{~S}$ & 629171 & 4167494 & 1067 \\
\hline ANEL06 & $10 \mathrm{~s}$ & 629313 & 4167300 & 1024 \\
\hline ANEL07 & $10 S$ & 629295 & 4167281 & 1005 \\
\hline ANEL08 & $10 \mathrm{~s}$ & 629230 & 4167229 & 972 \\
\hline ANEL09 & $10 \mathrm{~S}$ & 629174 & 4167201 & 971 \\
\hline ANEL10 & $10 \mathrm{~s}$ & 629149 & 4166992 & 937 \\
\hline ANEL11 & $10 \mathrm{~s}$ & 629046 & 4166911 & 936 \\
\hline ANEL12 & 105 & 628223 & 4166655 & 914 \\
\hline ANEL13 & $10 \mathrm{~s}$ & 629539 & 4168890 & 1097 \\
\hline ANEL14 & $10 S$ & 629963 & 4167412 & 1196 \\
\hline ANEL15 & $10 S$ & 629957 & 4167367 & 1141 \\
\hline ANEL16 & $10 \mathrm{~s}$ & 629368 & 4169782 & 1082 \\
\hline ANEL17 & $10 S$ & 628178 & 4169340 & 1313 \\
\hline ANEL18 & 105 & 628187 & 4169385 & 1384 \\
\hline ANEL19 & 105 & 628226 & 4169429 & 1252 \\
\hline ANEL20 & 105 & 628275 & 4169488 & 1235 \\
\hline ANEL21 & $10 \mathrm{~s}$ & 628415 & 4169685 & 1091 \\
\hline ANEL22 & $10 \mathrm{~s}$ & 631827 & 4167714 & 778 \\
\hline ANEL23 & $10 \mathrm{~s}$ & 631879 & 4167749 & 788 \\
\hline ANEL24 & 105 & 627743 & 4169903 & 1325 \\
\hline ANEL25 & $10 \mathrm{~s}$ & 628718 & 4167279 & 989 \\
\hline ANEL26 & $10 S$ & 628883 & 4167160 & 970 \\
\hline ANEL27 & $10 \mathrm{~s}$ & 629626 & 4166938 & 1095 \\
\hline ANEL28 & $10 \mathrm{~s}$ & 628354 & 4169473 & 1275 \\
\hline ANEL29 & $10 \mathrm{~s}$ & 628425 & 4169415 & 1400 \\
\hline ANEL30 & $10 S$ & 631791 & 4167522 & 900 \\
\hline ANEL31 & $10 \mathrm{~s}$ & 628743 & 4169462 & 1269 \\
\hline ANEL32 & $10 \mathrm{~s}$ & 629709 & 4167591 & 1007 \\
\hline ANEL33 & $10 \mathrm{~s}$ & 629528 & 4166971 & 964 \\
\hline ANEL34 & $10 \mathrm{~s}$ & 629355 & 4169776 & 1091 \\
\hline ANEL35 & $10 \mathrm{~s}$ & 628517 & 4169439 & 1378 \\
\hline ANEL36 & $10 \mathrm{~s}$ & 628647 & 4169478 & 1304 \\
\hline ANEL37 & $10 \mathrm{~s}$ & 628674 & 4169475 & 1309 \\
\hline
\end{tabular}




\section{Andusace elongata sse. acuta}

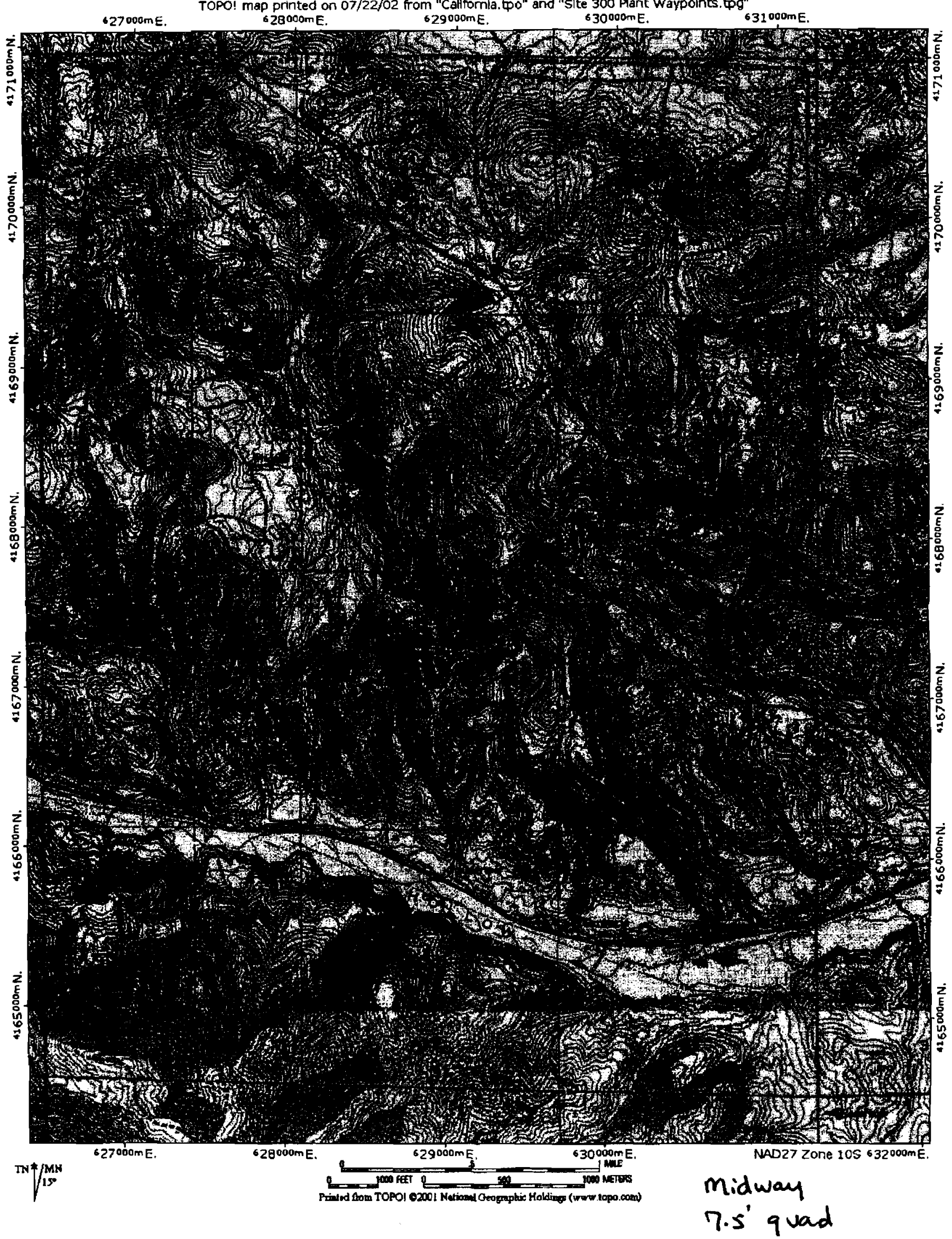




\section{California Native Species Field Survey Form}

Mail to:

Natural Diversity Database

Calffornia Department of Fish and Game

$180713^{\text {th }}$ Street, Sutte 202

Sacramento, CA 95814

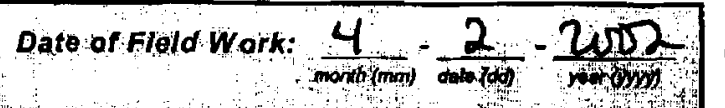

$\mathscr{C}$

\section{Source Code}

Elm Code

EO Index No.
For Office Use Only

Quad Code

Occ. No.

Map Index No.

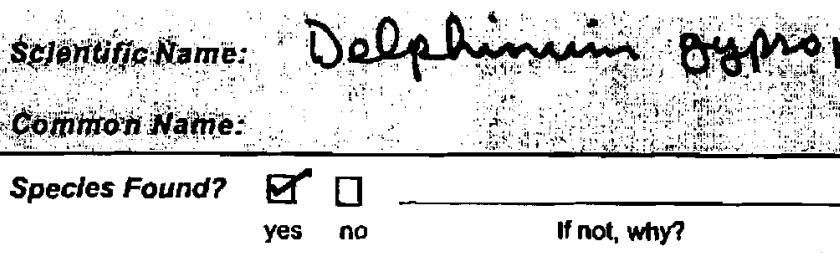

Total No. Individuals Subsequent Visit?

Is this an existing NDDB occurrence?

Yes, Occ.

Collection? If yes:

$$
\text { Number Museum / Herbarium }
$$

Plant Information

Phenology: $\frac{100 \%}{\% \text { vegelative }} \frac{\longrightarrow}{\% \text { flowering }} \frac{}{\% \text { fruiting }}$

Location (please also attach or draw map on back) Lalnatry, Site 300

county: San Logquin

Quad Name: Midwoun

TSS RYE $1 / 4$ of SW $1 / 4$ of Section 15

UTM: Zone: $(10,11)$ (GPS, map \& type, etc.)

Source:

Polnt Accuracy:

Datum:

Reporter: Jones + Stokes

Address: $2600 \mathrm{~V}$ Street Sacramento, CA 95818

Emall Addross: rereston ejsanet.com Phone: $(916)$ s03-6681

\section{Animal Information}

Age Structure:

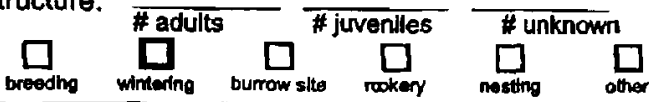

UTM Coordinates

Habitat Description (plant communities, dominants, associates, substrates/soils, aspocts/stopo)

Nature gransland

Other rare species?

Site information Overall site quality: DExcellent एGood $\square$ Fair $\square$ Poor

Current / surrounding land use:

Visible disturbances / possible threats: Ammual contuolled loums comments: 2 stands in eavly flever

Detormination: (check one or more, and it in blenks)

Deyed (cite oference)

Compared with specimen housed at:

$\square$ Compared with photo / drawing in: $\square$ Other.
Photographs: (aheok one or mort) Slide Print

Plant / animal

Habitat

Diagnostic feature

May we obtain duplicates at our expense? $\square$ yes $\square$ no 


\section{Delphimin gymorlilu}

TOPO! map printed on 07/22/02 from "California.tpo" and "Untltled.tpg"
$628000 \mathrm{mE}$.
$629000 \mathrm{~m}$. $630000 \mathrm{mE}$.
NAD27 Zone $10 S 631000 \mathrm{~m}$.

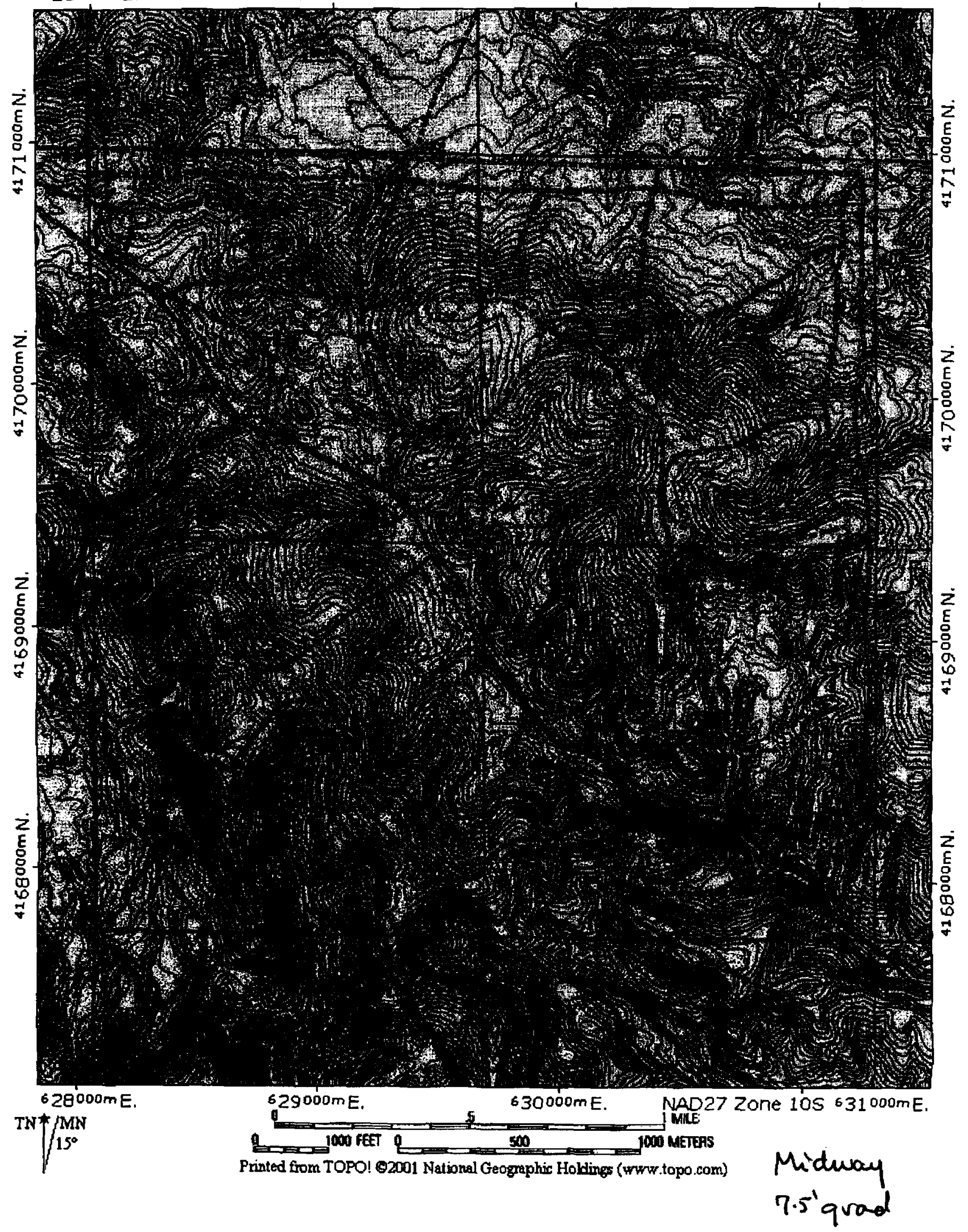


Mail to:

\section{California Native Species Field Survey Form}

Natural Diversity Database

California Department of Fish and Game

$180713^{\text {th }}$ Street, Sulte 202

Sacramento, CA 95814
$\mathscr{C}$

Source Code

Elm Code

EO Index No.
For Office Use Only

Quad Code

Occ. No.

Map Index No.

Date of Fierdwork. 4 - 12 - $\frac{2002}{100 m}$

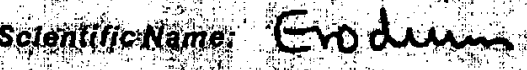

Con

macroplglim

conionnthe

Species Found?

$\square$

Total No. Individuals 192 Subsequent Visit? $\square$ yes 7 no

Is this an existing NDDB occurrence?

Yes, Occ. \#

Bío Dunk.

Collection? If yes:

Number

Museum / Herbarium

Plant Information

Phenology: $\frac{}{\% \text { vegetative }}-\frac{1}{\% \text { flowering }}-\frac{100 \% \geqslant 7 \text { fruiting }}{\%}$

Locetion (please also attach or draw map on back) Lalnating, Site 300

county: Alameda Landowner/Mgr.: US DOE

Quad Name: Midanay

T 3 S RY

$1 / 4$ of $n W 1 / 4$ of section $20 \quad T$

UTM: Zone: 10 $(10,11)$ (GPS, map \& type, etc.) Point Accuracy: 4 Datum: NAD 27 $\mathrm{R}$ Source: 6 SS UTM Coordinates $627264 \mathrm{E}, 4168879 \mathrm{~N}$

Habitat Description (plant communitios, dominants, associates, substrates/soils, aspocts/stopo) Aneas min anmal

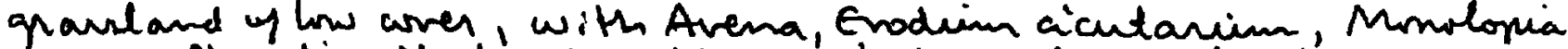
magior, Phacelia ciliato, lend dim mitidem. Amsinchia liy copsoides, Trifoliom windemavil, Triteldia Laxa, Achyrachaenamolus. Fn'able Other rare species? clay sivi.

SIte Information Overall site quality: पExcellent QGGood $\square$ Fair $\square$ poor

Current / surrounding land use:

Visible disturbances / possible threats:

comments: Alumst ale of the plants are in a fine brail-is distulare lemeficial, in thin case?

Determinatlon: (check one or more, end fil in blenks)

$\square$ Keyed (cite weference)

$\square$ Compared with specimen housed at:

$\square$ Compared with photo / drawing in:

Ey arother person (name): Roland Presth

$\square$ Other:

Reporter: Jones + Stokes

Address: $2600 \mathrm{~V}$ Street

Sacramento, CA 95818

Emall Address: rereston ejs a net. com Phone: (916) 503-6681

Animal Information

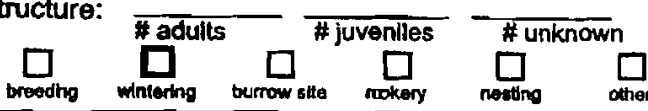

Laurence Livermene Natamal Elevation: $1,264^{\prime}$ $1 / 4$ of Section (NAD83,NAD 27,WG584, other) Meters 


\section{Midway 7.5' quad.}

TOPOl map printed on 07/22/02 from "California.tpo" and "Untitled.tpg"

$626000 \mathrm{mE}$.

$627000 \mathrm{mE}$.

NAD27 Zone $105629000 \mathrm{~m}$ E.

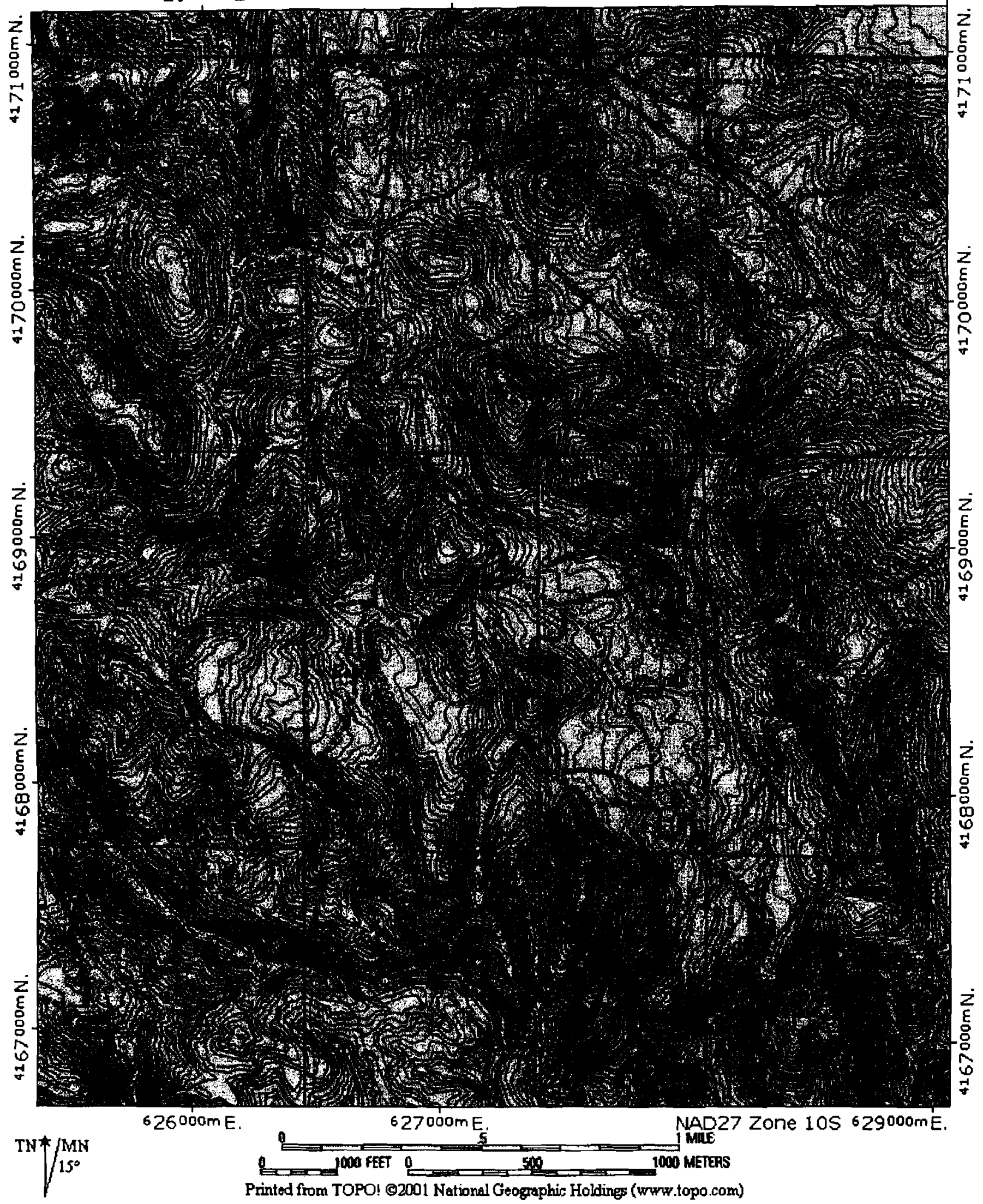

Evodiin maceophyllum 
Section B

Lawrence Livermore National Laboratory Livermore Site Assessment 
Section B

\section{Lawrence Livermore National Laboratory Livermore Site Assessment}

\section{Introduction}

\section{Methods}

The LLNL Livermore Site occupies approximately 821 hectares in the City of Livermore, California (Figure B-1). The site, which is developed except for a narrow buffer zone along the north and west sides, is occupied by laboratories and other buildings and facilities supporting the LLNL research programs. Because the LLNL Livermore Site is mostly developed, few surveys have been done there. The buffer zones support nonnative grassland (U.S. Department of Energy and University of California 1992). Two streams traverse the site, Arroyo Seco and Arroyo Las Positas. Arroyo Seco has a steep-sided channel that supports a canopy of both native willow and oak species as well as ornamental tree species such as eucalyptus and black locust (U.S. Department of Energy and University of California 1992). Arroyo Las Positas is a trapezoidal channel that was constructed to relocate the original stream channel. The vegetation in this channel consists primarily of freshwater marsh and ruderal wetlands, with a small stand of willows present (Jones \& Stokes Associates 1997). The previous studies concluded that special-status species were highly unlikely to occur at the Livermore Site because of the lack of native vegetation (U.S. Department of Energy and University of California 1992, Jones \& Stokes Associates 1997).

By querying the California Natural Diversity Database (2002) for the Altamont quadrangle, we generated a list of special-status plant species occurring in the vicinity of the LLNL Livermore Site. Table B-1 identifies the species most likely to occur at LLNL, the habitats they occur in, and the blooming period, at which time they would be most evident and identifiable.

A Jones \& Stokes botanist performed a reconnaissance survey at the LLNL Livermore Site on June 27, 2002. The focus of the survey was to identify potential habitat for special-status species and to survey any such habitat found. The buffer zones were examined by driving slowly through the area, stopping 
occasionally to record the plants present. A walking transect was done along the lengths of both Arroyo Seco and Arroyo Las Positas. The plants occurring along the transects were noted, and a running checklist was accumulated.

\section{Results}

Site conditions are relatively unchanged from that reported in earlier surveys (U. S. Department of Energy and University of California 1992, Jones \& Stokes Associates 1997). The buffer zones are vegetated by nonnative grasses dominated by wild oat (Avena), brome grasses (Bromus), and foxtail barley (Hordeum murinum subsp. leporinum), with scattered yellow-star thistle (Centaurea solstitialis), curly dock (Rumex crispus), and wild radish (Raphanus sativus). No wetlands, saline soils, or clay soils are evident; much of the soil in the buffer zone consists of fill that was transported there during facilities construction at other parts of the site.

Arroyo Seco is a well-incised channel that was dry on June 27. The tree canopy along the channel was composed of native and nonnative trees, including willows, oaks, California buckeye (Aesculus californica), glossy privet (Ligustrum lucidum), and black locust. Vegetation along the channel bottom and banks consisted of ruderal species, including perennial peppercress (Lepidium latifolium), sweet fennel (Foeniculum vulgare), Bermuda grass (Cynodon dactylon), and common cocklebur (Xanthium strumarium). The vegetation along Arroyo Las Positas was essentially as described in the 1997 delineation report (Jones \& Stokes Associates 1997).

No special-status species were observed at the Main Site. No suitable habitat was observed for any of the species in Table B-1. Table B-2 presents the list of plant species observed in Arroyo Seco. A list of species observed along Arroyo Las Positas is contained in the 1997 delineation report (Jones \& Stokes Associates 1997).

\section{References}

California Natural Diversity Data Base. 2002. RareFind 2, Version 2.1.2 (March 1, 2002 update). California Department of Fish and Game, Sacramento, CA.

Jones \& Stokes Associates, Inc. 1997. Delineation of waters of the United States for Arroyo Las Positas, Lawrence Livermore National Laboratory, Alameda County, California. November 7, 1997. (JSA 97-107). Sacramento, CA. Prepared for University of California, Lawrence Livermore National Laboratory, Livermore, CA. 
U.S. Department of Energy and University of California. 1992. Final Environmental Impact Statement and Environmental Impact Report for Continued Operation of Lawrence Livermore National Laboratory and Sandia National Laboratories, Livermore. DOE EIS/0157. 


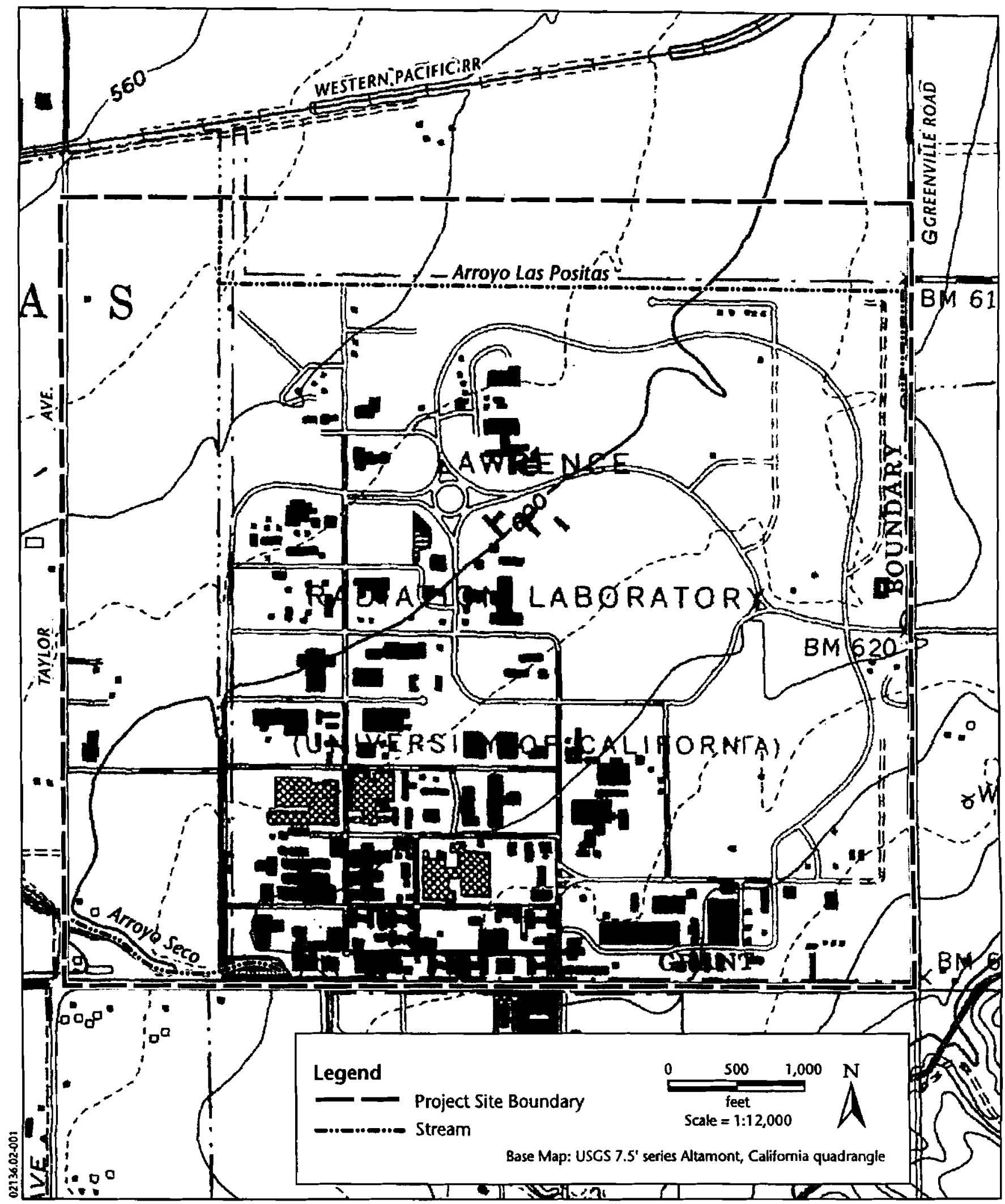

可留 Jones \& Stokes

Figure B-1

Lawrence Livermore National Laboratory, Livermore, California 
Table B-1. Special-Status Plant Species Occurring in the Vicinity of Lawrence Livermore National Laboratory Main Site

Page 1 of 2

\begin{tabular}{|c|c|c|}
\hline & $\begin{array}{l}\text { Listing } \\
\text { Status* }\end{array}$ & \\
\hline Common and Scientific Name & $\begin{array}{c}\text { Federal/State/ } \\
\text { CNPS }\end{array}$ & Habitat \\
\hline $\begin{array}{l}\text { Alkali milkvetch } \\
\text { Astragalus tene var. tener }\end{array}$ & $--/--/ 1 \mathrm{~B}$ & $\begin{array}{l}\text { Subalkaline flats and areas around vernal } \\
\text { pools; blooms March-June }\end{array}$ \\
\hline $\begin{array}{l}\text { Heartscale } \\
\text { Atriplex cordulata }\end{array}$ & $--/-/ 1 \mathrm{~B}$ & $\begin{array}{l}\text { Alkali grassland, alkali meadow, alkali } \\
\text { scrub; blooms May-October }\end{array}$ \\
\hline $\begin{array}{l}\text { Brittlescale } \\
\quad \text { Atriplex depressa }\end{array}$ & $-/--/ 1 B$ & $\begin{array}{l}\text { Alkali grassland, alkali meadow, alkali } \\
\text { scrub; blooms June-October }\end{array}$ \\
\hline $\begin{array}{l}\text { San Joaquin saltbush } \\
\text { Atriplex joaquiniana }\end{array}$ & $--/-/ 1 \mathrm{~B}$ & $\begin{array}{l}\text { Alkaline meadows, chenopod scrub; } \\
\text { blooms April-September }\end{array}$ \\
\hline $\begin{array}{l}\text { Big scale balsamroot } \\
\text { Balsamorhiza macrolepis }\end{array}$ & $--/-1 \mathrm{~B}$ & $\begin{array}{l}\text { Fields and rocky hillsides, below } 2,000 \\
\text { feet; grassland, foothill woodland; } \\
\text { blooms March-June }\end{array}$ \\
\hline $\begin{array}{l}\text { Hispid bird's-beak } \\
\text { Cordylanthus mollis ssp. hispidus }\end{array}$ & $--/-/ 1 \mathrm{~B}$ & $\begin{array}{l}\text { Alkaline meadows; blooms June- } \\
\text { September }\end{array}$ \\
\hline $\begin{array}{l}\text { Palmate bird's-beak } \\
\text { Cordylanthus palmatus }\end{array}$ & $\mathrm{E} / \mathrm{E} / 1 \mathrm{~B}$ & $\begin{array}{l}\text { Alkaline grasslands, chenopod scrub; } \\
\text { blooms May-October }\end{array}$ \\
\hline $\begin{array}{l}\text { Livermore tarplant } \\
\text { Deinandra bacigalupii }\end{array}$ & $-1-/ 1 \mathrm{~B}$ & Alkali meadow; blooms June-October \\
\hline $\begin{array}{l}\text { Mt. Diablo buckwheat } \\
\text { Eriogonum truncatum }\end{array}$ & $--1-/ 1 \mathrm{~A}$ & $\begin{array}{l}\text { Coarse sandy soil in grasslands; blooms } \\
\text { April-September }\end{array}$ \\
\hline $\begin{array}{l}\text { Round-leaved filaree } \\
\text { Erodium macrophyllum }\end{array}$ & $-1-/ 2$ & $\begin{array}{l}\text { Grasslands, on friable clay soils; blooms } \\
\text { March-May }\end{array}$ \\
\hline $\begin{array}{l}\text { Diamond-petaled California poppy } \\
\text { Eschscholzia rhombipetala }\end{array}$ & $--/--/ 1 \mathrm{~B}$ & $\begin{array}{l}\text { Clay soils in grasslands; blooms March- } \\
\text { April }\end{array}$ \\
\hline $\begin{array}{l}\text { Hairless popcorn flower } \\
\text { Plagiobothrys glaber }\end{array}$ & $--/-/ 1 \mathrm{~A}$ & Alkaline meadows; blooms April-May \\
\hline $\begin{array}{l}\text { Caper-fruited tropidocarpum } \\
\text { Tropidocarpum capparideum }\end{array}$ & $--1-1 A$ & $\begin{array}{l}\text { Grasslands in alkaline hills below } 500 \\
\text { feet; blooms March-April }\end{array}$ \\
\hline
\end{tabular}


*Status explanations:

Federal

-. = no status

$\mathrm{E}=$ Listed as "endangered" under the federal Endangered Species Act.

State

$--\quad$ no status

$\mathbf{E}=$ Listed as "endangered" under the California Endangered Species Act.

\section{California Native Plant Society}

$1 \mathrm{~A}=$ List 1A species: preseumed extinct.

$1 \mathrm{~B}=$ List 1B species: rare, threatened, or endangered in California and elsewhere.

$2=$ List 2 species: rare, threatened, or endangered in California but more common elsewhere.

3 = List 3 species: plants about which we need more information.

$4=$ List 4 species: Plants of limited distribution 
Table B-2. Checklist of Plant Species Observed in Arroyo Seco, Lawrence Livermore National Laboratory, June 27, 2002

Page 1 of 2

\begin{tabular}{|c|c|}
\hline Scientific Name & Common Name \\
\hline Aesculus californica & California buckeye \\
\hline Artemisia douglasiana & mugwort \\
\hline Artemisia californica & Califomia sagebrush \\
\hline Avena fatua & wild oat \\
\hline Baccharis salicifolius & mulefat \\
\hline Bromus diandrus & ripgut brome \\
\hline Bromus catharticus & rescue brome \\
\hline Carduus pycnocephalus & Italian thistle \\
\hline Carpobrotus sp. & ice-plant \\
\hline Cirsium vulgare & bull thistle \\
\hline Cynodon dactylon & Bermuda grass \\
\hline Cyperus eragrostis & umbrella sedge \\
\hline Epilobium canum & California fuschia \\
\hline Epilobium brachycarpum & panicled willow-herb \\
\hline Epilobium ciliatum & hairy willow-herb \\
\hline Eschscholzia californica & California poppy \\
\hline Euphorbia spathulata & reticulate-seeded spurge \\
\hline Foeniculum vulgare & sweet fennel \\
\hline Geranium dissectum & cut-leaved geranium \\
\hline Grindelia camporum & Great Valley gumplant \\
\hline Heliotropium curassavicum & salt heliotrope \\
\hline Hirschfeldia incana & Mediterranean mustard \\
\hline Hordeum murinum subsp. leporinum & foxtail barley \\
\hline Juglans sp. & black walnut \\
\hline Lactuca serriola & prickly lettuce \\
\hline Lepidium latifolium & perennial peppercress \\
\hline Leymus triticoides & creeping wildrye \\
\hline Ligustrum lucidum & glossy privet \\
\hline
\end{tabular}


Table B-2. Continued

\begin{tabular}{|c|c|}
\hline Scientific Name & Common Name \\
\hline Lolium multiflorum & Italian ryegrass \\
\hline Malva sp. & cheeseweed \\
\hline Marrubium vulgare & horehound \\
\hline Nicotiana glauca & tree tobacco \\
\hline Oxalis corniculatus & creeping wood sorrel \\
\hline Panicum capillare & witchgrass \\
\hline Paspalum dilatatum & Dallisgrass \\
\hline Piptatherum miliaceum & smilo grass \\
\hline Plantago lanceolata & English plantain \\
\hline Polypogon monspeliensis & annual rabbit's-foot grass \\
\hline Prunus dulcis & almond \\
\hline Pyracantha sp. & firethorm \\
\hline Quercus sp. & oak \\
\hline Raphanus sativus & wild radish \\
\hline Rumex salicifolius var. denticulatus & willow dock \\
\hline Rumex crispus & curly dock \\
\hline Salix lasiolepis & arroyo willow \\
\hline Senecio vulgaris & common groundsel \\
\hline Silybum marianum & milk thistle \\
\hline Sonchur oleraceus & common sow-thistle \\
\hline Tragopogon porrifolius & salsify \\
\hline Urtica dioica subsp. holosericea & hoary nettle \\
\hline Vitis vinifera & cultivated grape \\
\hline Xanthium strumarium & common cocklebur \\
\hline
\end{tabular}




\section{Section C \\ Vegetation Map and Natural Community Classification for Site $\mathbf{3 0 0}$}




\section{Section C Vegetation Map and Natural Community Classification for Site $\mathbf{3 0 0}$}

\section{Introduction}

In 2001, Jones \& Stokes updated BioSystems' 1986 vegetation study by more precisely delineating the boundaries between vegetation types and by mapping vegetation types that previously were not mapped. A comparison of the vegetation classification used in the 1986 and 2001 surveys is presented.

This section briefly outlines the methods used by Jones \& Stokes to map the vegetation of Site 300 and discusses the community type classification used to characterize the vegetation map units.

\section{Methods}

Before beginning the mapping effort, LLNL staff provided Jones \& Stokes with 1:8,000 scale false-color infrared photographs of Site 300 taken April 20, 1998, in both hard copy and electronic format; geographic information system (GIS) files with fire trails, facilities, elevations, and other features useful for site orientation; and previous reports documenting onsite biological resources.

Jones \& Stokes used this information to prepare a preliminary vegetation map based on photointerpretation and the information from the earlier reports. Field surveys were conducted by Jones \& Stokes botanists in August 2001 to note the vegetation types and verify the map unit boundaries. To more accurately delineate sensitive habitats, such as wetlands, Global Positioning System (GPS) data recorders were used to collect point locations and to record linear features and map unit polygons.

The GIS files were created from field delineated maps, GPS data, and field notes. The map units delineated on aerial photographs were digitized in AutoCAD R14. The GPS data were differentially corrected and the topology was cleaned up for positional errors. 


\section{Community Type Classification}

Community types used for the vegetation map (provided in attached map pocket) generally follow the List of California Terrestrial Natural Communities Recognized by the Natural Diversity Data Base (California Natural Diversity Database 1999). This list originated with the terrestrial natural communities descriptions of Holland (1986) and was expanded to incorporate the series classification system proposed in the Manual of California Vegetation (Sawyer and Keeler-Wolf 1995). Site 300 vegetation map units were assigned community types based on the dominant or characteristic plant species present. Table C-1 lists the community types included in the vegetation map, cross-referenced to the habitat types used in the BioSystems 1986 assessment of onsite vegetation communities. Although some of the community types are nearly equivalent to BioSystems' habitat types (e.g., Native Grassland vs. Cismontane Native Grassland), some of the community types used in the current map were not recognized in the BioSystems report.

The community types are numerically coded and are hierarchical. For example, the general category of Coastal Scrub is coded 32.000.00. Califomia Sagebrush Scrub, a type of Coastal Scrub, is coded 32.010.00. Whenever possible, a vegetation map unit was assigned a specific community type. In many cases, however, it was possible to classify a community type only to a general category because the vegetation had been burned or was otherwise not readily identifiable. The use of standard community codes will make it relatively easy to recode the map units to a more specific community type, based on additional field data, if that is desired.

\section{Natural Community Types}

\section{Coastal Scrub (32.000.00)}

Coastal Scrub is a shrub-dominated community occurring in the Coast Ranges within the area where the climate has a maritime influence. Although the BioSystems report recognized three types of Coastal Scrub at Site 300, its vegetation map did not differentiate between the types. In the present vegetation map, California matchweed (Gutierrezia californica) is the dominant shrub in most of the map units coded as coastal scrub. This map unit also includes stands dominated by other species, such as bush lupine (Lupinus albifrons), for which there is currently no equivalent California Natural Diversity Database (CNDDB) community type. 


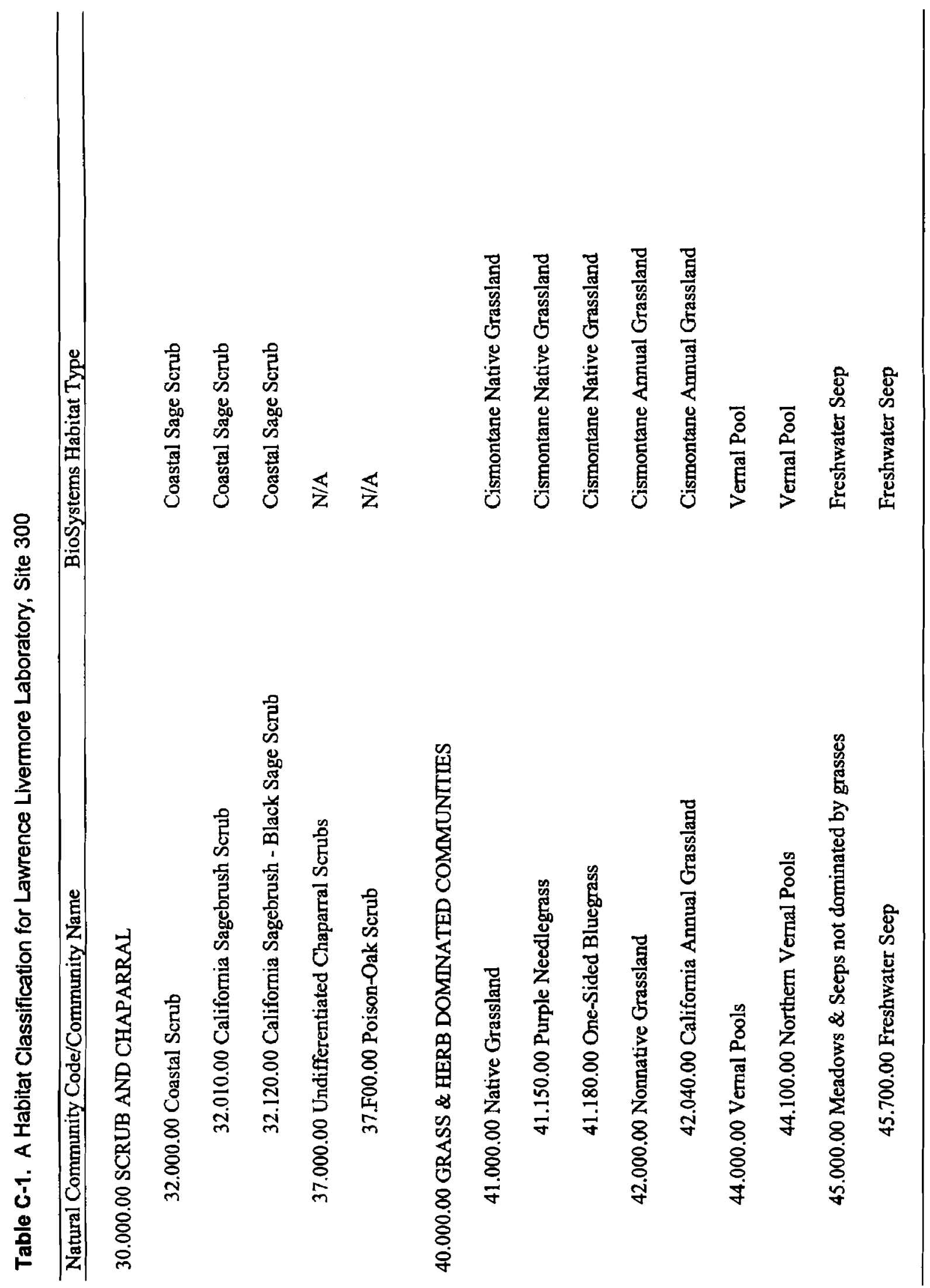


Table C-1. Continued

Page 2 of 3

Natural Community Code/Community Name

BioSystems Habitat Type

50.000.00 BOG AND MARSH

52.000.00 Marsh

Freshwater Seep

52.103.00 Cattail Wetland

Freshwater Seep

\subsubsection{RIPARIAN AND BOTTOMLAND HABITAT}

61.000.00 Riparian Forest and Woodland

N/A

61.130.00 Fremont Cottonwood Riparian Forest and Woodlands

N/A

63.000.00 Low to High Elevation Riparian Scrub

N/A

63.140.00 Great Valley Willow Scrub

N/A

63.400.00 Elderberry Scrub and Savanna

Northem Riparian Woodland

63.410.00 Mexican Elderberry

Northern Riparian Woodland

63.500.00 Baccharis Senubs

N/A

63.510.00 Mulefat Scrub

N/A 
70.000.00 BROAD LEAFED UPLAND TREE DOMINATED

71.000.00 Oak Woodlands and Forests

71.020.00 Blue Oak Woodland

71.020.05 Blue Oak/Grass

71.040.00 Valley Oak Forests and Woodlands

80.000.00 CONIFEROUS UPLAND FOREST AND WOODLAND

89.000.00 Juniper Woodlands

89.100.00 California Juniper Woodland and Scrub

89.100.01 Juniper-Oak Cismontane Woodland
Blue Oak Woodland

Blue Oak Woodland

Blue Oak Woodland

N/A

Cismontane Annual Grassland

N/A

N/A 


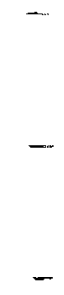

$-$

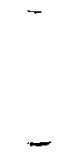

$-$ 


\section{California Sagebrush Scrub (32.010.00)}

California Sagebrush Scrub is a category of Coastal Scrub in which Califomia sagebrush (Artemisia californica) is the dominant shrub.

\section{California Sagebrush-Black Sage Scrub (32.120.00)}

California Sagebrush-Black Sage Scrub is a category of Coastal Scrub in which California sagebrush and black sage (Salvia mellifera) are both dominant species.

\section{Poison-Oak Scrub (37.F00.00)}

Poison-Oak Scrub is a scrub community dominated by poison oak (Toxicodendron diversilobum). This is a unique map unit that occurs in only one location at Site 300. BioSystems did not classify this habitat type. Poison-Oak Scrub is not currently included in the CNDDB classification, and we assigned it a community code modified from the code used in Holland (1986).

\section{Native Grassland (41.000.00)}

Native Grassland is a community dominated by native grasses, primarily onesided bluegrass (Poa secunda) and needlegrass (Nassella pulchra and N. cernua). This community type is equivalent to BioSystems' Cismontane Native Grassland habitat type. Because many areas of Native Grassland are managed by controlled burns, we could not assign most of the map units to a more specific category.

\section{One-Sided Bluegrass Grassland (41.180.00)}

One-Sided Bluegrass Grassland is a category of Native Grassland in which onesided bluegrass is a dominant species.

\section{California Annual Grassland (42.040.00)}

California Annual Grassland is a community dominated by annual grasses that were introduced from Mediterranean Europe during the Spanish colonial era. BioSystems mapped two habitat types corresponding to this map unit, xeric cismontane annual grassland and mesic cismontane annual grassland. We did not attempt to differentiate xeric and mesic grassland map units because of the drought conditions and because many of these areas had been burned. 


\section{Northern Vernal Pool (44.100.00)}

Three vernal pools occur at Site 300 . These vernal pools do not correspond to any of the vernal pool categories in the CNDDB classification and were, therefore, assigned to the general category of Northem Vernal Pool. BioSystems identified vemal pools at Site 300 but did not map their locations.

\section{Freshwater Seep (45.700.00)}

Freshwater Seep corresponds to BioSystems' Seeps \& Springs habitat type.

\section{Cattail Wetland (52.130.00)}

The BioSystems report included Cattail Wetland in the Seeps \& Springs habitat type. This community is dominated by cattails (Typha latifolia and $T$. angustifolia).

\section{Seasonal Pond}

Seasonal Pond designates areas that are seasonally inundated but do not have native wetland or vernal pool vegetation. The vegetation is sparse and consists of weedy wetland or ruderal species. Seasonal Pond does not have a corresponding CNDDB classification, and the BioSystems report did not identify this habitat.

\section{Fremont Cottonwood Riparian Forests and Woodlands (61.130.00)}

Fremont Cottonwood Riparian Forests and Woodlands habitat occurs along Corral Hollow Creek in the CDFG ecological reserve. The BioSystems report identified this habitat type as Woody Riparian Vegetation but did not map its location. The dominant species is Fremont cottonwood (Populus fremontii). The shrubby understory is open to dense, consisting primarily of mulefat and red willow (Salix laevigata). Although the stream channel was mostly dry at the time of the survey, several small seeps dominated by cattails were observed in the channel. Perennial peppercress (Lepidium latifolium) is a noxious weed that is present in the riparian zone. Elimination of this species from the ecological reserve should be part of the habitat management strategy. 


\section{Mexican Elderberry Scrub (63.410.00)}

Mexican Elderberry Scrub is a general category of scrub dominated by Mexican elderberry (Sambucus mexicanus). The BioSystems report mapped this area as Northern Riparian Woodland in Section 22. This vegetation unit does not correspond closely to any of the CNDDB community types, but it was categorized as Mexican Elderberry Scrub because one of the dominant species is Mexican elderberry.

\section{Mulefat Scrub (63.510.00)}

Sections of stream channel dominated by mulefat (Baccharis salicifolius) were classified as Mulefat Scrub. The BioSystems report included this vegetation unit with Seeps \& Springs.

\section{Great Valley Willow Scrub (63.140.00)}

Sections of stream channel along Elk Ravine dominated by willows (Salix species) were classified as Great Valley Willow Scrub. This community is an open to dense shrubby streamside thicket dominated by willows, occurring along the major rivers and tributaries throughout the Great Valley watershed (Holland 1986). The BioSystems report did not include this habitat type.

\section{Blue Oak/Grass Woodland (71.020.05)}

Blue Oak/Grass Woodland corresponds, in part, to the Blue Oak Woodland of the BioSystems report. The dominant species is blue oak (Quercus douglasii), with an understory dominated by annual grasses.

\section{Valley Oak Forests and Woodlands (71.040.00)}

Valley Oak Forests and Woodlands are dense to open tree-dominated communities in which valley oak (Quercus lobata) is a dominant species. Fremont cottonwood and willows are also present in the woody overstory in this map unit at Site 300. The BioSystems report discussed, but did not map, valley oaks at Site 300. 


\section{California Juniper Woodland and Scrub (89.100.00)}

California Juniper Woodland and Scrub is an open woody plant community dominated by California juniper (Juniperus californicus) with a shrubby understory of coastal scrub species. The BioSystems report did not differentiate this habitat type from Coastal Sage Scrub.

\section{Juniper-Oak Cismontane Woodland (89.100.01)}

Juniper-Oak Cismontane Woodland is an open woody plant community dominated by California juniper and blue oak. The BioSysterns report did not differentiate this habitat type from Blue Oak Woodland.

\section{Disturbed}

Areas that are paved, occupied by buildings, or otherwise cleared of vegetation were classified as Disturbed. Disturbed areas do not have a corresponding CNDDB classification. In the BioSystems report, this habitat type was only mapped for developed site facilities and was not applied to other areas, such as fire breaks.

\section{Urban Habitat}

Areas landscaped with ornamental trees and shrubs were classified as Urban Habitat. Urban Habitat does not have a corresponding CNDDB classification but is included in the California Wildlife Habitat Relationship system (Mayer and Loudenslayer 1988). In the BioSystems report, this habitat type was not differentiated from disturbed areas.

\section{References Cited}

BioSystems Analysis, Inc. 1986. Vegetation of Site 300, Lawrence Livermore National Laboratory, San Joaquin County, California. July 18, 1986. Santa Cruz, CA. Prepared for Science Applications International, Inc., Pleasanton, CA.

California Natural Diversity Database. 1999. List of California terrestrial natural communities recognized by the Natural Diversity Database. January, 1999. Natural Heritage Division, Department of Fish and Game, Sacramento, CA. 
Holland, R. F. 1986. Preliminary descriptions of the terrestrial natural communities of California. California Department of Fish and Game, Sacramento, CA.

Mayer, K. E., and W. F. Laudenslayer, Jr. (eds.). 1988. A guide to wildlife habitats of California. California Department of Forestry and Fire Protection. Sacramento, CA.

Sawyer, J. O., and T. Keeler-Wolf. 1995. A manual of California vegetation. California Native Plant Society, Sacramento, CA. 
